1989

\title{
Self, Others, and Section 7: Mutualism and Protected Protest Activities under the National Labor Relations Act
}

Michael Fischl

University of Connecticut School of Law

Follow this and additional works at: https://opencommons.uconn.edu/law_papers

Part of the Administrative Law Commons, and the Labor and Employment Law Commons

\section{Recommended Citation}

Fischl, Michael, "Self, Others, and Section 7: Mutualism and Protected Protest Activities under the National Labor Relations Act" (1989). Faculty Articles and Papers. 340.

https://opencommons.uconn.edu/law_papers/340 


\section{HEINONLINE}

Citation: 89 Colum. L. Rev. 7891989

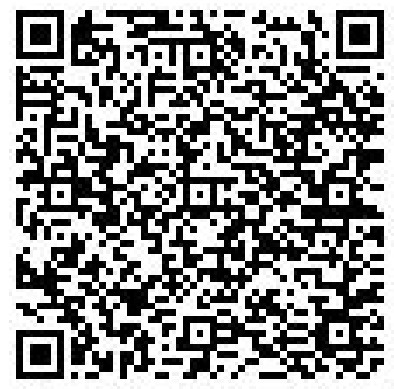

Content downloaded/printed from

HeinOnline (http://heinonline.org)

Mon Aug 15 16:52:33 2016

-- Your use of this HeinOnline PDF indicates your acceptance of HeinOnline's Terms and Conditions of the license agreement available at http://heinonline.org/HOL/License

-- The search text of this PDF is generated from uncorrected OCR text.

-- To obtain permission to use this article beyond the scope of your HeinOnline license, please use:

https://www.copyright.com/ccc/basicSearch.do?

\&operation $=$ go\&search Type $=0$

\&lastSearch $=$ simple\&all $=$ on\&titleOrStdNo $=0010-1958$ 


\title{
SELF, OTHERS, AND SECTION 7: MUTUALISM AND PROTECTED PROTEST ACTIVITIES UNDER THE NATIONAL LABOR RELATIONS ACT
}

\author{
Richard Michael Fischl*
}

\section{INTRODUCTION}

Section 7 of the National Labor Relations Act ("Act") is the principal source of legal protection for employees who engage in workplace protests. ${ }^{1}$ This provision recognizes the right of employees to join and bargain collectively through a union; it further guarantees that employees may-with or without a union-engage in strikes, picketing, and other "concerted activities," free from employer retaliation or restraint. $^{2}$ A substantial body of case law has evolved limiting the scope

* Associate Professor, University of Miami School of Law. Many thanks to Terry Anderson, Ken Casebeer, Wes Daniels, Pat Gudridge, Richard Hyland, Peter Junger, Jim Kainen, Duncan Kennedy, David Rabban, Alan Swan, and William Twining, and especially to John Ferguson, Dennis Lynch, and Jim Pope, for their thoughtful reactions to earlier drafts; to Luke Ferster and Ana Gloria Rivas-Vazquez for their superb research assistance; to Warren Rosmarin and Nora de la Garza for their tireless and cheerful efforts to locate obscure legislative and secondary materials; to Mary Coombs, Jeremy Paul, and Steve Winter, who were exceedingly generous with their time, insight, and encouragement; and to Pam Stancil, without whose aid and support this would never have been possible.

1. In pertinent part, the provision provides: "Employees shall have the right to self-organization, to form, join, or assist labor organizations, to bargain collectively through representatives of their own choosing, and to engage in other concerted activities for the purpose of collective bargaining or other mutual aid or protection ...." National Labor Relations Act \& 7, 29 U.S.C. \& I57 (1982) (N.L.R.A.). The quoted language reads essentially as it did in the original version of the Act as passed in 1935, Pub. L. No. I98, 49 Stat. 449 (the Waguer Act). The Labor Management Relations Act of 1947, Pub. L. No. 101, 61 Stat. 136 (the Taft-Hartley Act or the Taft-Hartley amendments), inserted the word "other" before the phrase "concerted activities," for reasons that are discussed infra note 137. The second major revision of the Act-the LaborManagement Reporting and Disclosure Act of 1959 -left the provision intact. See Pub. L. No. 357, 73 Stat. 541 (the Landrum-Griffin Act or the Landrum-Griffin amendments).

2. 29 U.S.C. $\S 157$. Technically, the guarantees of $\S 7$ are implemented against employer interference by the provisions of $\S 8(a)$ of the Act. Id. § 158(a). Most relevant here is $\$ 8(\mathrm{a})(1)$, id. $\$ 158(\mathrm{a})(1)$, which provides that "[i]t shall be an unfair labor practice for an employer ... to interfere with, restrain, or coerce employees in the exercise of the rights guaranteed by section [7]." Discharge in retaliation for $\$ 7$ activity is the classic example of the conduct prohibited by this provision. See, e.g., NLRB v. Washington Aluminum Co., 370 U.S. 9, 12-13 (1962) (discharge of employees for walkout protesting adverse working conditions violates $\S 8(\mathrm{a})(\mathrm{l}))$.

In the absence of protection under $\$ \S 7$ and $8(a)$, the employer would be free to discipline employees for virtually any reason he saw fit under the American common-law "employment-at-will" rule. See Epstein, ln Defense of the Contract At Will, 51 U. Chi. L. Rev. 947, 949 (1984); Feinman, The Development of the Employment at Will Rule, $20 \mathrm{Am}$. J. Legal Hist. 118, 125 (1976). The recent changes in the scope and effect of that rule, see, e.g., Note, Protecting Employees At Will Against Wrongful Discharge: 
of section 7 protection, and the limits imposed by the current reading of the provision's requirement that employees undertake their protest activities "for the purpose of ... mutual aid or protection"3 are the central focus of this Article. 4

A literal interpretation of this "mutuality" requirement might call into question the availability of legal protection for the employee who participates in a protest to support a colleague's cause-a strike, say, challenging the latter's discharge. Thus, the argument goes, since the protest at issue "aid[s]" and "protect[s]" only the employee whose personal claim is at stake - and not the individual who offers her supportit is not undertaken "for the purpose of . . mutual aid or protection" as required by section 7.5 Employers who would rid themselves of protesters have invoked this argument with surprising frequency during the

The Public Policy Exception, 96 Harv. L. Rev. 1931, 1950-51 (1983), have not, by and large, altered the employer's common-law prerogative to punish employee actions that threaten his economic well-being, his exclusive control of his property, or his authority to demand compliance with lawful directives. See Casebeer, Teaching an Old Dog Old Tricks: Coppage v. Kansas and At-Will Employment Revisited, 6 Cardozo L. Rev. 765, 784 (1985); Note, supra, at 1932. Since strikes, picketing, and other protest activities inevitably threaten some or all of those employer interests, $\& 7$ remains the principal source of protection for employees who engage in such conduct.

3. 29 U.S.C. $\& 157$ (emphasis added).

4. Karl Klare has astutely observed that "[i]t is extraordinary how much of the law of [§ 7] pertains to ways in which employees may lose rather than gain section 7 rights." Klare, The Public/Private Distinction in Labor Law, 130 U. Pa. L. Rev. 1358, 1403 n.196 (1982). Indeed, "breathtaking" may be a more apt description. Thus, in addition to the interpretation of the "mutuality" requirement discussed here, statutory protection for conduct otherwise protected by $\$ 7$ may be denied if the protest at issue interferes with the employer's property rights, e.g., WACO, Inc., 273 N.L.R.B. 746, 746-47 (1984) (peaceful sit-down strike in employee lunchroom held unprotected); if it represents an attempt by the employees to "set their own terms and conditions of employment," e.g., Audubon Health Care Center, 268 N.L.R.B. 135, 137 (1983) (refusal by employees to take on additional work); if it is deemed "insubordinat[e]," e.g., Bird Eng'g, Inc., 270 N.L.R.B. 1415, 1415 (1984) (noncompliance with employer's order to take lunchbreak on company premises); if it is deemed "disloya[l]" or "indefensible," e.g., NLRB v. Local Union No. 1229, Int'l Bhd. of Elec. Workers (Jefferson Standard Broadcasting Co.), 346 U.S. 464,472 (1953) (public challenge to quality of employer's product); if it constitutes a crime or tort, e.g., NLRB v. Fansteel Metallurgical Corp., 306 U.S. 240, 252 (1939) (sit-down strike that involved seizure of premises and sabotage); if it is unduly threatening to strikebreakers, e.g., Clear Pine Mouldings, Inc., 268 N.L.R.B. 1044, 1046 (1984) (verbal threats unaccompanied by physical gestures), enforced 765 F.2d 148 (9th Cir. 1985), cert. denied, 474 U.S. 1105 (1986); or if it violates the provisions of the employment contract, e.g., Mastro Plastics Corp. v. NLRB, 350 U.S. 270, 280 (1956) (strike in violation of no-strike clause).

For a thoughtful treatment of much of this jurisprudence-and criticism of the "values and assumptions" it reveals-see J. Atleson, Values and Assumptions in American Labor Law (1983).

5. 29 U.S.C. $\S 157$ (emphasis added). The standard dictionary definition of "mutual," for example, is "given and received in equal amount." Webster's Third New International Dictionary 1493 (1986); see also Safire, On Language: The Feeling Is Mutual, N.Y. Times, Nov. 27, 1988, \& 6, at 20 (Sunday Magazine) ('mutual-rooted in the Latin for 'exchange'-implies reciprocity"). 
fifty-odd years since the passage of the Wagner Act. I say surprising because the National Labor Relations Board and the courts have almost invariably rejected the argnment out of hand. Their analyses uniformly take as a starting point a passage from Judge Learned Hand's opinion in NLRB v. Peter Cailler Kohler Swiss Chocolates Co.: 6

When all the other workmen in a shop make common cause with a fellow workman over his separate grievance, and go out on strike in his support, they engage in a "concerted activity" for "mutual aid or protection," although the aggrieved workman is the only one of them who has any immediate stake in the outcome. The rest know that by their action each one of them assures himself, in case his turn ever comes, of the support of the one whom they are all then helping; and the solidarity so established is "mutual aid" in the most literal sense, as nobody doubts. ${ }^{7}$

Under the prevailing interpretation of this passage, the individual who comes or is called to the aid of a fellow employee is deemed to be acting for "the purpose of . . . mutual aid or protection" because of an implied promise of a reciprocal benefit to herself; in the case of the individual who protests her colleague's dismissal, she is presumed to "know by [her] action" that she has enhanced the likelihood that the one she helps will come to her own aid, should she one day end up in the same boat. The invocation of this "promise of reciprocal benefit" has permitted the Board and the courts to find the requisite "mutuality"-and thus to protect the protests at issue-in a broad range of contexts.

But the use of this interpretation of section 7 has had less salutary effects as well. It has led to the development of a legal discourse that takes as given an opposition between self and others in the workplace-an opposition that is belied by the experience of solidarity in the protests at issue and in worklife generally. Indeed, this discourse has helped to shape the way labor lawyers, Board members, and judges think about labor law and has therefore frequently influenced decisional results. This Article will explore and criticize these effects, and what they reveal about the conceptual foundations of American labor law. ${ }^{8}$

6. 130 F.2d 503 (2d Cir. 1942).

7. Id. at 505-06. The facts and reasoning of Peter Cailler are discussed at length at infra notes $285-98$ and accompanying text.

8. I will not attempt here to offer anything like a complete account of the connections between and among ideology, legal discourse, and decisional results. The materials explored, however, do suggest how doctrine might be at once legitimating-at least among those who participate in the discourse-and indeterminate. Thus, as is the case in so many other legal contexts, the "rule" (protester self-interest is the predicate for $\S 7$ protection) is swallowed up by the "exception" (self-interest can almost invariably be found in the "promise of reciprocal benefit"); either result (protester wins/protester loses) is therefore possible in any given case, at least if we take the decision makers' rhetoric of justification seriously. At the same time, however, the "exception" itself reflects and reinforces a discourse of self-interest. In this sense, my view is similar to the 
Part I examines a series of contexts in which the Labor Board and the courts have invoked the Peter Cailler "promise of reciprocal benefit" to justify statutory protection for employees who give "aid or protection" to other workers. It shows that this interpretive strategy imposes real-and not just rhetorical-constraints on section 7 rights. "Because the "promise of reciprocal benefit" gambit accepts the premise that the support employees afford each other must be moved by selfish ends, it has frequently worked to undermine legal protection for employeesthose, for example, who honor picket lines-whose direct personal stake in the outcome of the protests they join may seem too attenuated to be plausibly attributed to self-interest.

Part II explores section 7's treatment of a situation that is the mirror image of the one examined in Part I: the individual who seeks the aid of others in support of her own cause. Once again, the Board and the courts invoke the "promise of reciprocal benefit," and once again this rhetorical strategy limits the scope of protection available for employees. Here, the strategy devalues the individual whose personal plight is at stake by treating her as a mere means to her colleagues' selfinterested ends. When, for example, an employee attempts to secure the presence of a fellow worker at a disciplinary interview, statutory protection may be denied in a number of settings on the ground that the reciprocal benefit to her co-workers is insufficient.

Part III suggests that the phenomena revealed in Parts I and II are at work in numerous contexts quite apart from the interpretation and application of the mutuality requirement. The rejection of solidarity as a legitimate basis for joining protest activity is evident in the treatment under section 7 of the confidential employee who supports a protest by her rank-and-file colleagues. Similarly, the devaluation of the employee whose personal claim is at stake is apparent in the debate concerning the proper interpretation of section 7's requirement that protests be undertaken on a "concerted" basis. Finally, the phenomena are present as well in the current treatment of collective bargaining by the rankand-file on behalf of their retired colleagues-an area altogether outside the formal reach of section 7.

Part IV considers and rejects the argument that the "promise of reciprocal benefit" interpretation is compelled by the language or orig-

notion of "privileged positions" described in M. Kelman, A Guide to Critical Legal Studies 290-95 (1987).

The materials explored here also suggest how we might begin to account for the experience of law as simultaneously indeterminate and predictable. Thus, although either result (protester wins/protester loses) is possible, they are not in equipoise. Indeed, the burden of this piece is to show that the common commitment of both rule and exception to a regime of self-interest has had a systematic and identifiable impact in a host of contexts. For a wonderfully ambitious effort to account for this sort of experience through the use of recent developments in cognitive theory, see my colleague Steve Winter's Transcendental Nonsense, Metaphoric Reasoning, and the Cognitive Stakes for Law, 137 U. Pa. L. Rev. 1107 (1989). 
inal intent of the mutuality requirement. Drawing upon the work of labor historian David Montgomery, Part IV suggests that this interpretation ignores the contemporaneous understanding of "mutualism" in the labor movement-an understanding that is consistent with the legislative history of the provision as well.9 This notion of mutualism reflected the experience of working-class bondings and struggles and, in stark contrast with the commitment to individual self-interest suggested by the "promise of reciprocal benefit," embraced the values of community, sympathy, and solidarity. Finally, Part IV attempts to show that Judge Hand's opinion in Peter Cailler has long been misunderstood and that Hand was of the view that it was labor solidarity, not simply the prospect of reciprocal benefit, that constitutes the "mutual aid or protection" described by section 7 .

Parts I-IV tell a second, related story as well. Traditionally, the courts have been more likely than has the Board to interpret section 7 to require a convincing showing of protester self-interest. The Board, by contrast, has tended to view most protest activity-whatever its apparent motivation-as within the plain meaning of section 7 and accordingly has protected relatively selfless protests with far greater frequency. And while the agency has permitted a substantial body of judicial disagreement with its approach to go virtually unanswered, Part IV offers strong historical support for the Board's intuitive institutional commitment to this more capacious notion of "mutual aid or protection."

Part $\mathrm{V}$ argues for a richer understanding of the motives that underlie employee protest activities. Building upon the insights of recent feminist scholarship, Part V suggests that the "promise of reciprocal benefit" - and the contractual imagery it invokes-assumes a relationship between self and others that is oppositional and thus obscures the sense of solidarity and genuine connection among working people, born of their experience of workplace struggles. Indeed, I contend here that the dominance of contractual imagery in current labor discourse has less to do with assumptions about the forms of association and interaction among employees than with our widely shared notion of the "natural" and appropriate relationship between employees and the other "other" in the workplace: the employer.

\section{Giving "Aid or Protection"}

\section{A. Solidarity Reinterpreted: The "Mutuality" Requirement}

1. Hendricks and Eastex: The Golden Rule Revisited. - Before I started teaching law, I worked for several years as an attorney for the Labor Board, whose decisions I defended in the federal courts. My first assignment was Hendricks County Rural Electric Membership Corp. , ${ }^{10}$ which 
involved the discharge of Mary Weatherman, the secretary to the general manager of a rural electric company in Indiana. ${ }^{11}$ Weatherman was fired for signing a petition, addressed to the company's board of directors, protesting the dismissal of fellow employee Lloyd Hadley. Hadley, in turn, was an electrical worker who had been with the company for nearly 15 years, and had himself been dismissed because he had lost an arm in an on-the-job accident and was no longer able to climb utility poles. ${ }^{12}$

I will never forget the emotional force of the offending petition, which was signed by about two-thirds of the company's employees and bore Weatherman's signature prominently toward the top of the list:

We, as employees of the [Company], feel that we cannot let what has happened to Lloyd Hadley pass without at least expressing our feelings. We realize what we say may not be able to change anything; but we cannot, in good consci[ence], remain silent.

It seems that the problem is no one is willing to speak up or defend what is right if it might mean jeopardizing one's own self. As long as you take care of number one, yourself, no one else matters. Well, other people do matter and Lloyd Hadley matters, to us and to many other people.

No one has given this Company more than Lloyd has. Anyone who ever worked with him ... has been amazed at the amount of work he could do.

I'm sure none of us can even begin to imagine the amount of suffering Lloyd endured during his recovery. One of his most driving forces was his desire to be able to come back to work. He may not be able to climb a pole anymore, but that is just one of the few things he can't do. Because a man cannot do "everything" does not mean that he cannot be a valuable employee. Lloyd is certainly still capable of being a great asset to this Company. We wonder if any of you ever took the time to inquire as to what he still can do, or if you ever saw all the things he has made, or know that he rebuilt a transmission by himself since his accident.

You hear much talk today about employees not wanting to give a full day's work for a full day's pay, and not having any pride in their job; well, you just lost one that did. But, what about the other side. Doesn't a company owe any kind of loyalty to an employee? When an employee gives you 15 years of

sued, 247 N.L.R.B. 498, enforcement denied, 627 F.2d 766 (7th Cir. 1980), rev'd with instructions to enforce, 454 U.S. 170 (1981).

11. The issue that troubled the court of appeals-and eventually split the Supreme Court 5-4-was whether the discharged secretary was a "confidential employee" and for that reason outside the protection of the Act. See 454 U.S. at 190-91 (upholding the Labor Board's decision that she was not); see also infra notes 112-28 and accompanying text (discussing $§ 7$ rights of confidential employees).

12. 236 N.L.R.B. at 1617. 
work, doing more than his share, and then almost gives his life, is this what he gets in return?

You have made your decision; but, we wonder, is there a possibility of reconsideration? ${ }^{13}$

Nor will 1 ever forget the strange way in which the Labor Board interpreted that courageous and moving document. A threshold issue in the case was whether Weatherman, in signing the petition, was engaged in a protest undertaken "for the purpose of . . . mutual aid or protection" and therefore protected by section 7 against retaliatory discharge by her employer. ${ }^{14}$ The employer argued, among other things, that the petition "concerned the plight" of only the injured Hadleyand not of the siguatory employees-and that it therefore did not constitute a protest warranting statutory protection. ${ }^{15}$

The Board rejected that argument, but its explanation suggested that it accepted the employer's premise that section 7 would not protect a petition motivated solely by the signing employees' concern for Hadley. Citing Peter Cailler, the Board reasoned that:

[1]n circulating the petition, the signers clearly had in mind not only Hadley's welfare but also their own future well being.

It seems plain that the Hadley case touched a collective nerve which inspired a group of ordinary citizens, who might not be individually "willing to speak up" because "it might mean jeopardizing one's own self," to boldly band together, finding needed strength in unity. And, in so uniting, they sought to arouse in [their employer] a "kind of loyalty" which might not only serve Hadley's interest but also their own as well. By sparking some compassion for Hadley, the employees might have focused [the employer's] attention on the need for greater generosity toward the work force as a whole. By taking up the cudgels for Hadley, the employees might have moved [the employer] to appraise future disability retirement actions pertaining to themselves more conscientiously and deliberately. And, by obtaining Hadley's return to work and his successful performance thereof, the employees might have paved the way for their own return to work in similar circumstances. ${ }^{16}$

Imagine my surprise. I had thought that the petition was inspired primarily by the employees' belief that "other people do matter," by their feelings for Hadley, and by their outrage over the obvious injus-

13. Brief for the National Labor Relations Board on Petition for Review and CrossApplication for Enforcement at 5, Hendricks County Rural Elec. Membership Corp. v. NLRB, 603 F.2d 25 (7th Cir. 1979) (No. 78-2127) (on file at the Columbia Law Review); see also 236 N.L.R.B. at 1620 (opinion of Board).

14. See supra note 2 (describing legal protection against discharge for exercise of $\S 7$ rights).

15. 236 N.L.R.B. at 1620. The employer's argument is further elaborated at infra note 292.

16. 236 N.L.R.B. at 1620 (emphasis added). 
tice done him by their employer. And I had thought that they had undertaken their protest despite their perceived self-interest in the matter-fully aware that "speak[ing] up . . . might mean jeopardizing one's own self" (which turned out to be a very real concern for the discharged Weatherman). That, after all, is what the petition said. But, according to the Board, what justified section 7 protection for the employees' protest was the asserted fact that the signers "had in mind... their own future well being." They were "serv[ing]" their "own" interests by pressing the employer for "greater generosity" in Hadley's case, thus enhancing the possibility of better treatment by the employer should they one day find themselves in his predicament. The Board did not-and could not-altogether ignore the employees' stated concern for Hadley. But, standing alone, that concern apparently did not warrant statutory protection for the petition.

My research soon revealed that Hendricks was not an aberration. The assumption almost invariably emerges in section 7 cases that support rendered by employees to their fellow workers enjoys statutory protection only to the extent that it can be construed as-or, in the case of Hendricks, misconstrued as-self-interested. In Eastex, Inc. v. NLRB, ${ }^{17}$ for example, the Supreme Court faced the question whether section 7 protected an attempt by unionized employees to circulate at their workplace a newsletter protesting, among other things, a presidential veto of a congressionally authorized increase in the minimum wage. ${ }^{18}$ The principal issue in the case was whether the newsletter's assertedly "political" (as opposed to "work-related") character placed it outside of section 7.19

17. 437 U.S. 556 (1978).

18. The newsletter read, in pertinent part:

POLITICS and INFLATION

The Minimum Wage Bill, HR 7935, was vetoed by President Nixon. The President termed the bill as inflationary. The bill would raise the present $\$ 1.60$ to $\$ 2.00$ per hour for most covered workers. . . .

Congress is now pr[o]ceeding with a second minimum wage bill that hopefully the President will sign into law. At $\$ 1.60$ per hour you could work 40 hours a week, 52 weeks a year and never earn enough money to support a family.

As working men and women we must defeat our enemies and elect our friends. If you haven't registered to vote, please do so today. . . .

Id. app. at 577-78.

19. See id. at 558,561 . The narrow question before the Court was whether the employer violated the employees' $\S 7$ rights by prohibiting the union's distribution of the newsletter to employees on the employer's premises. Id. Under prevailing law, that question turned on two conceptually distinct issues: whether the place, manner, and timing of the distribution were covered by $\S 7$, and whether the newsletter's contents were so covered. With respect to the former issue, the general rule is that employee distributions are protected against employer interference so long as they take place outside of actual working time (for example, during coffee or lunch breaks) and in a place and manner that do not disrupt production or discipline. See, e.g., Republic Avia- 
Most relevant here, however, was the employer's claim that its employees' immediate interest in the minimum-wage issue was too slight to warrant statutory protection, since they already earned more than the vetoed bill would have required. ${ }^{20}$ The Court accepted without discussion the underlying premise that protester self-interest was a necessary prerequisite to section 7 coverage, but, upholding the Labor Board, it concluded that the newsletter's contents implicated the selfinterest of the Eastex employees in two respects. First, the Court invoked the promise of reciprocal benefit, asserting that the " concern by the [Eastex] employees for the plight of other employees might gain support for them at some future time when they might have a dispute with their [own] employer." "21 Second, the Court, relying on two standard labor-economics textbooks, ${ }^{22}$ observed that " "the minimum wage inevitably influences wage levels derived from collective bargaining, even those [like Eastex's] far above the minimum." "23 The Court stressed this second rationale in particular, asserting that the possibility of this upward effect upon union wages "would not have been lost on [the Eastex] employees."24

It may well be the case that the employees in Eastex were as craftily self-interested as the Court's reasoning suggests. The fascinating thing about the case, however, is that the newsletter on its face suggested that the only motive behind the distribution at issue was the employees' concern not for themselves, but for other workers-in the words of the newsletter, for those who would "never earn enough money to support a family" because they were forced to "work 40 hours a week, 52 weeks a year" at the lower minimum-wage rate. ${ }^{25}$ Perhaps the newsletter's authors were being disingenuous, but the Court made no such claim and gave no hint as to why it did not accept them at their word. Indeed, the Court's analysis makes no reference whatsoever to the actual con-

tion Corp. v. NLRB, 324 U.S. 793, 803 n.10 (1945). The union proposed to undertake the subject distribution in a manner that complied with those rules, 437 U.S. at 559-61; accordingly, the issue before the Court was whether the newsletter's contents warranted $\S 7$ protection, notwithstanding their "political" flavor. The Court held that they did, observing nonetheless that "[t]here may well be types of conduct or speech that are so purely political or so remotely connected to the concerns of employees as employees as to be beyond the protection of [\$ 7]." $1 \mathrm{~d}$. at $570 \mathrm{n} .20$. For a thoughtful challenge to the distinction between "political" and "economic" activities by labor unions, see Hyde, Economic Labor Law v. Political Labor Relations: Dilemmas for Liberal Legalism, 60 Tex. L. Rev. 1 (1981); see also J. Atleson, supra note 4, at 73-75, 207 n.34 (same).

20. 437 U.S. at 569-70; see Eastex, Inc., 215 N.L.R.B. 271, 274 (1974) (Board decision).

21. 437 U.S. at 569 (quoting 215 N.L.R.B. at 274 (citing General Elec. Co., 169 N.L.R.B. 1101,1103 (1968))).

22. Id. at 570 n.19 (citing N. Chamberlain, Sourcebook on Labor 435-37 (1958);

L. Reynolds, Labor Economics and Labor Relations 272 (5th ed. 1970)).

23. 1d. at 569.

24. Id. at 570.

25. See supra note 18 . 
tents of the newsletter or to any other portion of the record. Rather, it simply offers the bald assertion that what really moved the Eastex employees was their own interest in the minimum-wage issue. ${ }^{26}$

Labor law thus puts a curious twist on the Golden Rule. Workers may do unto others as they would have others do unto them, but-to receive legal protection against employer interference with their protest-they must do so in a manner that will permit the Labor Board and the courts to pretend plausibly that what they are "really" up to is doing for themselves.

2. Board Literalism vs. The Judicial Search for Self-Interest. - As cases like Hendricks and Eastex suggest, both the Board and the courts assume that protester self-interest is a prerequisite to section 7 protection. The courts, however, have traditionally been far more likely to insist upon actual proof of such self-interest than has the Labor Board. Across a broad range of factual and doctrinal contexts, the Board has deployed a "plain meaning" argument, taking the position that employees who help others are literally engaged in "concerted activit[y] for the purpose of . . . mutual aid or protection," irrespective of their actual or apparent reasons for doing so. 27

Because terse boilerplate is virtually all that appears in the Board's opinions, it is not clear why Board members have adhered to this position in the face of a substantial body of judicial disagreement. At one extreme, individual Board members may embrace the literalist argument because they sincerely believe that uninterpreted language can (and should) decide the cases before them. At another, they may deploy that argument because they can find no better one available to support views they hold on grounds that they are unwilling to disclose in a written opinion. ${ }^{28}$ The truth may be more complicated.

For one thing, the Board eschews inquiry into the subjective motives of employees in a variety of cases and advances quite sensible reasons for doing so. ${ }^{29}$ Indeed, this policy is frequently cited in cases that

26. To be fair, the Court's failure to provide record support for its assertions may in part be attributable to the prevailing Board policy that prohibits any inquiry into the subjective motivation of employees who engage in $\$ 7$ conduct. See infra note 29 and accompanying text. Thus, it is perhaps not surprising that the Court declined to look beyond the "four corners" of the newsletter. What is surprising is what they found when they looked to the newsletter itself.

27. See infra notes 61-63 and accompanying text (solidarity-based refusals to cross picket lines); infra notes 74-75 and accompanying text (fear-based refusals to cross picket lines); see also infra note 115 and accompanying text (unfair-labor-practice protection for confidential employees).

28. Duncan Kennedy refers to these contrasting decisional styles as "naive" and "cynical" manipulation, respectively. D. Kennedy, Constitutionalism as a Randomizing Factor in American Political Culture: Notes of an Atheist 8 (Nov. 2, 1987) (unpublished manuscript) (on file at the Columbia Law Review).

29. For numerous contexts in which employee state-of-mind is ostensibly a material issue, the test applied is an objective one-what the employees would reasonably have intended or understood in all the circumstances. See, e.g., NLRB v. Gissel Packing Co., 
might otherwise call into question the motives of employees who come to the aid or protection of others. ${ }^{30}$ Moreover, some notable exceptions notwithstanding, it is very much a part of the agency's institutional culture for its personnel to take longstanding Board interpretations of the so-called plain meaning of the Act very seriously -in part to maintain decisional stability, but in part as well on the not unreasonable view that early Board decisions captured the meaning of the Wagner Act in a way that is simply inaccessible to the reader today. ${ }^{31}$ Indeed, as it turns out, the Board's interpretation of the expression "mutual aid or protection" to cover solidarity-based as well as self-interested protests comes far closer to the original meaning of the expression than does the Peter Cailler gloss. ${ }^{32}$ But by adopting its literalist approach without further explanation, the Board has left virtually unchallenged the judicial assumption that self-interest is a necessary prerequisite to section 7 protection. Moreover, in the face of what it

395 U.S. 575, 608 (1969) (approving objective test for determining employee's motive in signing union authorization card and expressly "reject[ing] any rule that requires a probe of an employee's subjective motivations"); Darlington Mfg. Co. v. NLRB, 397 F.2d 760, 772-73 (4th Cir. 1968) (test for determining whether employer conduct is unlawful is whether effect on employee union sentiments is "reasonably foreseeable," not whether "an actual chilling effect" resulted), cert. denied, 393 U.S. 1023 (1969). The rationale for this policy varies somewhat with the context. But when the question to be decided is the motive behind employee action or conduct, the cases reveal two common themes. First, there is the concern that an administrative inquiry into subjective motivation would be "endless and unreliable." Gissel, 395 U.S. at 608. Moreover, there is the fear that such an inquiry might chill the $\S 7$ rights of other workers. Assume, for example, that the Board were to uphold a challenged discharge upon a finding that the protester in question had the "wrong" subjective motive. The concern is that the discharged protester's colleagues might not understand, agree with, or in any event trust the Board's conclusions in this respect and thus might in the future be chary of exercising their own right to protest, even for the "right" reasons. Cf. NLRB v. Burnup \& Sims, 1nc., 379 U.S. 21, 23-24 (1964) (permitting discharge of employees engaged in $\S 7$ activity on basis of employer's mistaken belief that they also engaged in unprotected misconduct would "chill" rights of other workers).

30. See, e.g., Cooper Thermometer Co., 154 N.L.R.B. 502, 504 (1965) (fear-based refusal to cross a picket line), discussed infra notes 74-75 and accompanying text.

31. Cf. NLRB v. Bell Aerospace Co., Div. of Textron, 416 U.S. 267, 274-75 (1974) ("a court may accord great weight to the longstanding interpretation placed on a statute by an agency charged with its administration"). 1t bears noting, however, that the Board's embrace of plain-meaning arguments has also served less benign ends. During the mercifully brief heyday of Chair Dotson's reign at the agency in the mid-1980's, the Board on several occasions adopted the "just-following-the-literal-dictates-of-the-Act,Ma'am" line in order to justify dramatic reversals of settled precedent favorable to employee rights under $\S 7$. Ironically, this approach did not fare well in the courts of appeals, which seemed to prefer that the Board exercise its policy making discretion more forthrightly. The result, alas, was mostly an exercise in mandatory administrative candor; on remand, the agency usually reaffirmed the Dotson Board's original conclusions, but at least it did so in opinions that gave policy reasons-such as they were-for its action. See, e.g., infra note 104 (discussing the convoluted journey of the Board's decision in duPont); infra notes 132-33 \& 157 (discussing Meyers and Darling).

32. See infra notes $264-84$ \& $294-96$ and accompanying text. 
perceives to be a."hard case" (like Hendricks or Eastex) or a vigorous challenge from an opposing employer, the Board itself will frequently adopt the Peter Cailler analysis, suggesting that, when push comes to shove, its members have also shared the judicial commitment to a regime of self-interest. ${ }^{33}$

\section{B. The Limits of Solidarity: Protection for Workers Who Honor Picket Lines}

The interpretive strategy evident in Hendricks and Eastex-relying on Peter Cailler and re-interpreting selflessness as self-interest-has been adopted in countless decisions in order to protect the protest activity at stake. ${ }^{34}$ But the commitment to a regime of self-interest is more than rhetorical; there are certain recurring situations in which that commitment may strongly influence decisional results. This phenomenon is perhaps most evident in cases involving section 7's treatment of employees who honor picket lines, cases in which the fruitless

33. The Board's failure to join issue with the courts is not merely academic, for the agency must seek enforcement of its orders in the federal courts of appeals in order to secure the compliance of the losing party. See N.L.R.A. $\S 10(e), 29$ U.S.C. $\$ 160($ e) (1982). To be sure, losing parties acquiesce in a substantial majority of the Board's decisions. See, e.g., 52 NLRB Ann. Rep. 208-09 (1989) (table 7) (reporting that losing parties complied with or acquiesced in over $70 \%$ of decisions issued by Board and its administrative law judges during fiscal year 1987, the most recent year for which figures are available). But that phenomenon is surely attributable in no small part to the correctly perceived futility of challenging most decisions on appeal, see id. at 245 (table 19) (reporting that Board secured full or partial judicial enforcement in $81 \%$ of cases between fiscal years 1936 and 1987), rendering acquiescence far less likely when in-circuit precedent is available that is adverse to the Board.

34. Although Hendricks and Eastex provide particularly striking examples of this phenomenon, many other Board and court decisions employ the same gambit to justify statutory protection for protests that do not appear to have been motivated by self-interest. See, e.g., B. \& P. Motor Express, Inc. v. NLRB, 413 F.2d 1021, 1023 (7th Cir. 1969) (alternative holding) (walk-out in support of fellow employee's pay rate and overtime dispute); Morrison-Knudsen Co. v. NLRB, 358 F.2d 411, 413-14 (9th Cir. 1966) (protest respecting onerous working conditions of fellow employees); Summit Mining Corp. v. NLRB, 260 F.2d 894, 897 (3rd Cir. 1958) (strike in support of discharged fellow workers); NLRB v. Solo Cup Co., 237 F.2d 521, 525 (8th Cir. 1956) (strike in support of discharged fellow worker); American Lebanese Syrian Associated Charities, Inc., 277 N.L.R.B. 1532, 1544 (1986) (advising fellow employee on strategy for obtaining wage increase); Kawasaki Motors Corp., 268 N.L.R.B. 936, 949, 951 (1984) (protest of discharge of fellow worker); Intermountain Rural Elec. Ass'n, 253 N.L.R.B. 1153, 1163 (1981) (alternative holding) (attempt by employee to assist fellow worker during disciplinary interview), enforced in relevant part, 732 F.2d 754, 763 (10th Cir.), cert. denied, 469 U.S. 932 (1984); Supreme Optical Co., 235 N.L.R.B. 1432, 1433 (1978) (testimony at unemployment compensation hearing of discharged employee), enforced, 628 F.2d 1262 (6th Cir. 1980), cert. denied, 451 U.S. 937 (1981); Hennepin Broadcasting Assocs., Inc., 225 N.L.R.B. 486, 498 (1976) (strike in support of discharged fellow employee), enforced 96 L.R.R.M. (BNA) 2585 (8th Cir.), cert. denied, 434 U.S. 823 (1977); Pauley Paving Co., 200 N.L.R.B. 861, 864 \& n.3 (1972) (work stoppage to aid discharged employee), enforced mem., 490 F.2d 1407 (4th Cir. 1974); Washington Forge Inc., 188 N.L.R.B. 90, $97 \&$ nn.28-30 (1971) (alternative holding) (work stoppage protesting working condition that directly affected only other employees). 
search for direct protester self-interest has frequently undermined the workers' claims for section 7 protection.

1. Solidarity-Based Actions. - When employees strike in support of the grievance of a fellow worker, the prospect that protesters are moved by a "promise of reciprocal benefit," though surely only a part of the story, is at least plausible. Thus, the employee aided by the efforts of her fellow workers is not only likely to be inclined to render reciprocal support in the future; by virtue of her status as an employee of the same enterprise, she will also be in a position to make that support count by joining in a strike or other work action against the common employer. Accordingly, it is not surprising that the search for selfinterest in this context has generally led the courts to accord section 7 protection to the protest activity in question. ${ }^{35}$

A somewhat more complicated problem arises, however, when the beneficiaries of the strike are not the protesters' fellow employeeswhen workers honor a so-called "stranger" picket line at a firm doing business with their employer. ${ }^{36}$ Given the absence of any direct personal stake in the outcome of the underlying (or primary) dispute, the question arises as to how much protection the courts will be willing to afford such employees. As Professor Atleson and others have suggested, the cases have frequently denied section 7 protection in this context, and a principal reason appears to be that the refusing employee's stake in the dispute is understood solely on the limited basis of her own admittedly attenuated self-interest. ${ }^{37}$

35. See, e.g., B. E P. Motor Express, 413 F.2d at 1023 (protection accorded to strike in support of fellow employee's pay rate and overtime dispute); Summit Mining, 260 F.2d at 897 (protection accorded to strike in support of discharged employees); Solo Cup, 237 F.2d at 526 (same). Protection also appears to be generally available for the related situation in which employees aid and support fellow workers who are in a bargaining unit that is represented by a different union, as in the cases in which the former refuse to cross the picket line of the latter, see, e.g., NLRB v. Union Carbide Corp., 440 F.2d 54, 55-56 (4th Cir.), cert. denied, 404 U.S. 826 (1971), or refuse to do struck work, see, e.g., Allbritton Communications, Inc., 271 N.L.R.B. 201 (1984), enforced, 766 F.2d 812 (3d Cir. 1985), cert. denied, 474 U.S. 1081 (1986). Even here, however, the commitment to self-interest has occasionally resulted in a rejection of $\S 7$ protection for protesting employees. See, e.g., NLRB v. Illinois Bell Tel. Co., 189 F.2d 124, 129 (7th Cir.) (denying protection where protesters' actions "could have only been for the benefit and aid of those in a different bargaining unit, the representative of which could not have represented the involved employees and, consequently, could have obtained nothing from [the employer] for [the protesters'] benefit'), cert. denied, 342 U.S. 885 (1951).

36. See, e.g., NLRB v. Browning-Ferris Indus., Chem. Servs., Inc., 700 F.2d 385 (7th Cir. 1983) (refusal by truck drivers to cross picket line on premises of employer's customer). The persistent use of the word "stranger" to describe the relationship between employees of different employers may itself reflect judicial discomfort with the idea of social bonds among working people that extend beyond their immediate selfinterest in their own employment to broader notions of working-class consciousness or solidarity. Cf. id. at 391 (Coffey, J., concurring) (criticizing "[w]orking class solidarity" as a basis for according $\S 7$ protection to refusal to cross stranger picket line).

37. See J. Atleson, supra note 4, at 69-77; C. Gregory \& H. Katz, Labor and the 
The phenomenon is somewhat more complex, however, than earlier analyses suggest. The Labor Board, for its part, has almost invariably held that honoring a picket line is protected activity under section 7,38 a position that finds support in the legislative history of the Wagner and Taft-Hartley Acts. ${ }^{39}$ And the clear trend in the courts is to

Law 108-11 (3d ed. 1979); see also Carney \& Florsheim, The Treatment of Refusals to Cross Picket Lines: "By-Paths and Indirect Crookt Ways," 55 Cornell L. Rev. 940, 968-69 (1970) (arguing for legal protection limited to situations where employee economic self-interest is most pronounced); Haggard, Picket Line Observance as a Protected Concerted Activity, 53 N.C.L. Rev. 43, 94-99 (1974) (arguing that protection should require "proof that the picket line observer does reasonably stand to obtain a concrete economic benefit by virtue of his act").

38. With the exception of a handful of decisions rendered during the Eisenhower administration, the Board has consistently adhered to this view since as early as $\mathbf{1 9 5 0 .}$ See Case Comment, Refusals to Cross Stranger Picket Lines and the Wealth Maximization Principle: An Economic Analysis of the Views of the NLRB and Judge Posner, 41 U. Miami L. Rev. 533, 547-50 \& n.80 (1987). The position is generally traced to Cyril de Cordova \& Bros., 91 N.L.R.B. 1121 (1950), which appears to be the first case directly to confront the issue in the stranger picket line context. Earlier Board decisions, however, had accorded statutory protection to employees honoring picket lines directed at their own employer by employees in other bargaining units and laad done so in terms that would seem to cover the stranger case as well. See, e.g., Illinois Bell Tel. Co., 88 N.L.R.B. 1171, 1176 \& nn.18-19 (1950) (collecting cases), enforcement denied, 189 F.2d 124 (7th Cir.), cert. denied, 342 U.S 885 (1951); see also infra note 277 (discussing early Board decisions that recognized worker solidarity and sympathy as valid $\S 7$ interests).

39. In brief, the view that Congress intended to provide $\$ 7$ protection for refusals to cross picket lines consists of two propositions: (I) the original Wagner Act protected such conduct, along with a host of other sympathetic actions; and (2) Congress deliberately left picket-line protection intact when it otherwise restricted secondary sympathetic activity in a number of specific ways through the Taft-Hartley and Landrum-Griffin amendments. The first proposition is the point of Part IV of this Article, which argnes that the "mutual aid or protection" langnage of $\S 7$ was broadly intended to protect labor solidarity. The evidence for the second proposition-that the Taft-Hartley and Landrum-Griffin amendments purposely exempted refusals to cross picket lines-has been thoroughly and persuasively marshalled elsewhere. See Getman, The Protection of Economic Pressure by Section 7 of the National Labor Relations Act, 115 U. Pa. L. Rev. 1195, 1227-29 (1967); Axelrod, The Statutory Right to Respect a Picket Line, 83 Dick. L. Rev. 617, 627-31 (1979); see also Truck Drivers Union Local No. 413 v. NLRB, 334 F.2d 539, 543-45 (D.C. Cir.) (same), cert. denied, 379 U.S. 916 (1964). To be sure, some confusion arises from the fact that the drafters of the Landrum-Griffin amendments spoke on occasion as if they thought they were leaving intact a right to secure picket line protection through contract, rather than an entitlement that had its source in § 7. See, e.g., H.R. Rep. No. 741, 86th Cong., 1st Sess. 21 (1959), reprinted in 1 NLRB Legislative History of the Labor-Management Reporting and Disclosure Act, at 779 (I959). But confusion in 1959 about the source of the right at stake is not surprising. In the first place, the Board had itself vacillated somewhat on the issue during the Eisenhower years. See supra note 38. Moreover, the picket-line case that would no doubt have been most on the minds of the members of the 86th Congress was NLRB v. Rockaway News Supply Co., 345 U.S. 71 (1953), which could easily have led even a labor lawyer to the conclusion that the source of the right was contract. Thus, the Court in Rockaway News addressed the issue of picket-line protection in the face of a broad nostrike clause. Id. at 79. It therefore did not reach the question of $\S 7$ protection, id., 
accept this position, at least in principle. ${ }^{40}$ Where the Board and the courts part company today is on the question of how to tailor this section 7 right to accommodate the employer's countervailing prerogative to "run his business"- -specifically, with respect to whether and when an employer is free to replace or discharge employees who honor a stranger picket line. The claim here is that this divergence may be largely a result of the fact that the Board views the right to picket line observance as per se section 7 activity and accordingly gives relatively little weight to the employer's asserted interest in thwarting it. By contrast, the courts ground the right in the self-interest of the protesters and, finding little or none, strike the resulting balance in favor of the employer. ${ }^{41}$

holding instead that whatever such protection exists can be-and, on the facts of that case, had been-waived by such a provision, id. at 76, 79-80. On the current state of waiver doctrine as it applies to honoring picket lines, see infra note 49 .

40. See, e.g., Business Servs. By Manpower, Inc. v. NLRB, 784 F.2d 442, 452-53 (2d Cir. 1986); NLRB v. Alamo Express, Inc., 430 F.2d 1032, 1036 (5th Cir. 1970), cert. denied, 400 U.S. 1021 (1971); Browning-Ferris, 700 F.2d at 387-88; NLRB v. Southern Cal. Edison Co., 646 F.2d 1352, 1363-64 (9th Cir. 1981); NLRB v. Gould, lnc., 638 F.2d 159, 163 (10th Cir. 1980) (dictum), cert. denied, 452 U.S. 930 (1981); Teamsters, Local 657 v. NLRB, 429 F.2d 204, 205 (D.C. Cir. 1970) (per curiam). Circuits assumed by some to be aligned against protection have, in fact, either not directly faced the issue, see NLRB v. William S. Carroll, Inc., 578 F.2d 1, 3 (1st Cir. 1978) (finding that even if $\$ 7$ covered employees who respect picket lines, such protection should be denied on facts); see also NLRB v. C.K. Smith \& Co., 569 F.2d 162, 165 \& n.1 (1st Cir. 1977) (dictum suggesting that no protection is available), cert. denied, 436 U.S. 957 (1978), or have apparently retrenched from earlier positions, compare NLRB v. L.G. Everist, Inc., 334 F.2d 312, 317-18 (8th Cir. 1964) (denying protection) with Montana-Dakota Utils. Co. v. NLRB, 455 F.2d 1088, 1091 (8th Cir. 1972) (assuming existence of protection, but holding protection waived by contract). As recounted supra note 39 , the Supreme Court had an occasion to confront the question but avoided it in Rockaway News, 345 U.S. at 79.

41. The Board and the courts now seem to have ceased their fruitless efforts to resolve the issue of protection on the basis of the employer's motives. To be sure, all concerned seem to agree that the Act condemns the employer whose adverse action is motivated by "animus" toward \$ 7 rights-for the purpose of punishing his employee for honoring a picket line, rather than to further his "legitimate business purposes." See Business Servs. by Manpower, 784 F.2d at 446-51 (collecting cases). Yet the agency and the reviewing courts have differed substantially with respect to the allocation of burdens and quantum of proof on that issue. The Board has held that the employer must establish that he was moved only by business considerations in order to escape liability for action taken against a refusing employee. See, e.g., Redwing Carriers, Inc., 137 N.L.R.B. 1545, 1547 (1962), aff'd sub nom. Teamsters Local Union No. 79 v. NLRB, 325 F.2d 1011 (D.C. Cir. 1963), cert. denied, 377 U.S. 905 (1964). By contrast, the First Circuit has insisted that the Board must establish that retaliation was the dominant motive behind the challenged conduct, if the employer first demonstrates some legitimate business interest for his action. See Carroll, 578 F.2d at 4; J. Atleson, supra note 4, at 75-76. With the caselaw thus arrayed, the Board and the courts would partake in a sort of minuet. The Board would tend to dismiss out of hand the employer's showing of a business reason as a mere pretext for retaliation; and the reviewing court would, in turn, emphasize the supposed objective merit of the employer's claim and reject the Board's finding of pretext as unsupported by substantial evidence. See, e.g., 
In the Board's current view, an employer may never discharge an employee for refusing to cross a picket line. ${ }^{42}$ The employer may permanently replace her, ${ }^{43}$ but it may do so "only when the employer's

Southern Cal. Edison Co., 243 N.L.R.B. 372, 373 (1979), enforcement denied in relevant part, 646 F.2d 1352, 1369 (9th Cir. 1980); Carroll, 232 N.L.R.B. at 1133-34, enforcement denied, 578 F.2d at 4-5.

More recent cases, however, seem to turn less on motive than upon a "balancing" of the contending interests-a trend that at least has the advantage of permitting the Board and the courts to exit from their vicious circle. See infra notes $42-73$ and accompanying text. After all, opposition to an employee's exercise of $\S 7$ rights may itself be premised upon the most "legitimate" of all business considerations: a concern for the bottom line. Deliveries delayed may be profits denied. See J. Atleson, supra note 4, at 75 (noting that "antiunion and business motivations are often simply two sides of the same coin"). This is not to say that sentiments of the sort suggested by the use of the word "animus" are not frequently evident among employers. See, e.g., Management Recalcitrance During Organizing Still Prevalent, NLRB Member Babson Says, Daily Lab. Rep. (BNA) No. 136, at A-3 (July 15, 1988) (departing Reagan appointee expresses "surpris[e]" at "large number" of Board cases that involve "traditional egregious management violations"). It is rather to suggest that, whatever the case with Holmes's dog, employees would prefer to be neither kicked nor tripped over. See O. Holmes, The Common Law 3 (1881).

Of course, the presence of demonstrable animus may itself be sufficient to establish that the employer's "legitimate" interest in the adverse action was insubstantial. Cf. Montgomery Ward \& Co. v. NLRB, 692 F.2d 1115, 1124 (7th Cir. 1982) (making similar argument in connection with restrictions on union access to employer property), cert. denied, 461 U.S. 914 (1983). But even from a doctrinal standpoint, it is not at all clear that the reverse is true and that proof of animus should ever be necessary in this context. There is seldom any question in these cases that the refusing employees would not have been disciplined but for their $\$ 7$ conduct. And absent a showing of a substantial and objective business justification for the challenged adverse action, that is enough to constitute an unfair labor practice under N.L.R.A. $\$ 8(a)(1), 29$ U.S.C. $\$ 158(a)(1)$ (1982), whatever the employer's motive. See R. Gorman, Basic Text on Labor Law: Unionization and Collective Bargaining 132-33 (1976). The same would probably be true even if the issue were analyzed under $\$ 8(\mathrm{a})(3), 29$ U.S.C. $\$ 158(\mathrm{a})(3)$, as the First Circuit urged in Carroll, 578 F.2d at 4; see NLRB v. Great Dane Trailers, Inc., 388 U.S. 26, 33-34 (1967) (even when employer's adverse action has only a " 'comparatively slight" " effect upon $\S 7$ rights, the Board need not establish motive under $\S 8(a)(3)$ unless "employer has come forward with evidence of legitimate and substantial business justifications for the conduct" (citations omitted)).

42. The lead case on the question is Torrington Constr. Co., 235 N.L.R.B. 1540, 1541 \& $n n .10-12$ (1978). See generally Case Comment, supra note 38, at 562-64 \& n.154 (discussing development of Torrington doctrine). The Reagan Board has overruled Torrington in a respect not pertinent here. See Butterworth-Manning-Ashmore Mortuary, 270 N.L.R.B. 1014, 1015 n.7 (1984), review denied sub nom. Public Professional \& Office-Clerical Employees and Drivers Local 763 v. NLRB, 767 F.2d 933 (9th Cir. 1985), discussed infra note 49. Yet the Board has otherwise adhered to the principles of that case. Butterworth-Manning, 270 N.L.R.B. at 1015 n.7 ("We leave undisturbed the remaining principles enunciated in Torrington."); see, e.g., Business Servs. by Manpower, Inc., 272 N.L.R.B. 827, 827 n.3, 828 \& n.9 (1984) (following Torrington).

43. The distinction between "discharge" and "permanent replacement" in labor law is more siguificant than at first it sounds:

Discharge severs the employment relationship entirely; should the discharged worker apply for reemployment[,] he would have to take his turn in the queue with any other applicants. In contrast, a worker who has been permanently 
business need ... is such as clearly to outweigh the employee's right to engage in protected activity." 44 The Board takes this "business necessity" test quite seriously, and employers have seldom been able to meet it to the agency's satisfaction. ${ }^{45}$ Thus, it is rarely the case that an employer must actually go out and hire a replacement in order to make the deliveries in question or to do the refused work since other current employees are usually willing and able to do so. ${ }^{46}$ lndeed, the Board has even suggested that management may have to turn to its supervisory personnel to handle the refused work, ${ }^{47}$ and that it must be willing to live with a loss of business due to the delays occasioned by making such alternative arrangements or to the departure of disgruntled customers. ${ }^{48}$ Only a confluence of factors that truly place the employer "between a rock and a hard place"-when, for example, the refused work involves a major client, there are no other current employees available to undertake the task, and the employer has no alternative work to give the refusing employee- has established the requisite business necessity. ${ }^{49}$

replaced jumps to the head of the queue; in addition, he is entitled to notice of job openings; most important, he retains his seniority.

Browning-Ferris, 700 F.2d at 389; Torrington, 235 N.L.R.B. at 1541 \& n.11; see The Developing Labor Law 228 (C. Morris 2d ed. 1983 \& Supp. III 1988).

44. Overnite Transp. Co., 154 N.L.R.B. 1271, 1274 (1965), enforced in part sub nom. Truck Drivers and Helpers Local No. 728 v. NLRB, 364 F.2d 682 (D.C. Cir. 1966) (per curiam).

45. In the last three decades, the Board has found employer showings of business necessity sufficient on only four occasions-all of them prior to 1975. See Overnite Transp. Co., 212 N.L.R.B. 515, 516, 523 (1974); Overnite Transp. Co., 209 N.L.R.B. 691, 692 (1974); Thurston Motor Lines, 166 N.L.R.B. 862, 866 (1967); Redwing Carriers, 137 N.L.R.B. 1545, 1546-47 (1962), review denied sub nom. Teamsters Local 79 v. NLRB, 325 F.2d 1011 (D.C. Cir. 1963), cert. denied, 377 U.S. 905 (1964).

46. See, e.g., Southern Cal. Edison Co., 243 N.L.R.B. 372,373 (1979) (replacement of refusing employee constitutes an unfair labor practice where employer was able to get another current employee to do the refused work), enforcement denied in relevant part, 646 F.2d 1352, 1369 (9th Cir. 1981).

47. See, e.g., Smith Transit, Inc., 176 N.L.R.B. 1074, 1084 (1969) (citing supervisors' availability to do refused work to support rejection of employer's business necessity defense); see Case Comment, supra note 38, at 578 \& n.209 (discussing Smith Transit).

48. See, e.g., Business Servs. by Manpower, Inc., 272 N.L.R.B. 827, 828-29 (1984), enforcement denied, 784 F.2d 442 (2d Cir. 1986); William S. Carroll, Inc., 232 N.L.R.B. 1131, 1131 n.1 (1977), enforcement denied, 578 F.2d I (1st Cir. 1978).

49. See Overnite Transp., 209 N.L.R.B. at 692. See generally Case Comment, supra note 38, at 577-84 (discussing factors that have moved Board to find "business necessity"); Axelrod, supra note 39, at 649-54 (same). Of course, the rights of both the employer and the employees may, under prevailing doctrine, be altered by contract. Thus, an employer can purchase-and a union can waive-the $\S 7$ right of its employees to honor picket lines; conversely, an employer can sell to the union his right under Board decisions to replace refusing employees, even if he would have been justified in doing so by business necessity. See, e.g., Indianapolis Power \& Light Co., 273 N.L.R.B. 1715, 1715 (1985) (waiver of $\S 7$ rights), remanded on other grounds sub nom. Local 1395, Int'l Bhd. of Elec. Workers v. NLRB, 797 F.2d 1027 (D.C. Cir. 1986); Butterworth- 
The courts, by contrast, permit discharge as well as replacement ${ }^{50}$ and apply something more akin to a "business convenience" test in evaluating challenged employer conduct, rejecting the Board's far more stringent approach. In a typical formulation, the Second Circuit recently suggested that employees who honor stranger picket lines should be protected against discharge only if their replacement "could be achieved with little or no disruption in the employer's operations, or with only a harmless delay."51 Similarly, the Ninth Circuit-while apparently accepting the Board's factual finding that an employer had no urgent business need-nevertheless upheld a replacement, explaining simply that the employer "was allowed ... to maintain reasonable, normal business operations." 52

Especially revealing is Judge Richard Posner's opinion in a Seventh

Manning-Ashmore Mortuary, 270 N.L.R.B. 1014, 1015 (1984) (employer's right to replace), review denied sub nom. Public, Professional \& Office-Clerical Employees and Drivers Local Union No. 763 v. NLRB, 767 F.2d 933 (9th Cir. 1985).

Considerable confusion attends the related question of how such waivers are to be accomplished. The Supreme Court, for its part, has held that a waiver of $\S 7$ rights must be "clear and unmistakable." Metropolitan Edison Co. v. NLRB, 460 U.S. 693, 708 (1983); see also NLRB v. Southern Cal. Edison Co., 646 F.2d 1352, 1364 \& n.3 (9th Cir. 1981) (applying clear-and-unmistakable standard in sympathy strike context). Turning that salutary principle on its head, and overruling the approach taken by the Carter Board, the Reagan Board has declared that a no-strike clause that makes no reference to any duty to cross picket lines nevertheless presumptively imposes such an obligation, "unless the contract as a whole or extrinsic evidence demonstrates that the parties intended otherwise." Indianapolis Power \& Light Co., 291 N.L.R.B. No. 145, 130 L.R.R.M. (BNA) 1001, 1003 (Dec. 9, 1988). The Board's commitment to that presumption seems, however, to be primarily rhetorical. Its treatment of the facts in Indianapolis Power suggests that it will not, in fact, require a labor union to establish that it has successfully secured the employer's agreement to "contract out" of the presumption. Instead, it appears that the union will prevail merely upon a showing that it did not agree to apply the no-strike clause to sympathy strikes. See id. at 1004 (finding no waiver because " "parties had agreed to disagree over whether sympathy strikes were covered" "); see also id. (Johansen, concurring) (arguing that result in Indianapolis Power is difficult to square with majority's professed adherence to presumption that no-strike clauses cover sympathy strikes).

At the same time, the Board has been willing to accord employers the full benefit of the clear and unmistakable waiver requirement-notwithstanding the dubious application of that standard to a party with no $\S 7$ rights to waive and that, in any event, represents itself at the bargaining table. See Metropolitan Edison, 460 U.S. at 708 (waiver requirement applies to "statutorily protected right[s]"). Thus, the agency has held that an employer who contractually agrees that a refusal to cross a picket line "shall not be cause for discharge or disciplinary action" does not "clearly and unmistakably" waive his right permanently to replace a refusing employee. Butterworth-Manning, 270 N.L.R.B. at 1015. The Carter Board had reached the opposite conclusion in Torrington. See supra note 42.

50. See, e.g., Business Servs. by Manpower, Inc. v. NLRB, 784 F.2d 442, 453-54 (2d Cir. 1986); NLRB v. William S. Carroll, Inc., 578 F.2d 1, 3 (1st Cir. 1978).

51. Business Servs. by Manpower, 784 F.2d at 454 (emphasis added), denying enforcement to 272 N.L.R.B. 827 (1984).

52. Southern Cal. Edison, 646 F.2d at 1369, denying enforcement in relevant part to 243 N.L.R.B. 372,373 (1979). 
Circuit decision, NLRB v. Browning-Ferris Industries, Chemical Services, Inc. ${ }^{53}$ Robert Andrus and Florian Ciukaj worked as truck drivers for Browning-Ferris lndustries (BFl), a nonunion chemical waste disposal firm. On February 21, 1980, they encountered a picket line at the premises of one of BFl's customers, International Harvester. They refused to cross and were immediately permanently replaced. ${ }^{54}$ The Board found that BFI could with little difficulty have dispatched two of its other four drivers, all of whom were willing to cross the picket line in question, rather than dismissing Andrus and Ciukaj, its most senior drivers. ${ }^{55}$ The Board reasoned:

The evidence is clear that International Harvester was the only customer whose employees were engaged in a strike. The evidence is also clear that from February 21 to the end of the strike at lnternational Harvester, Respondent [BF1] received one order for two drivers (March 18) from this customer. Keeping in mind that from February 20 to the end of the International Harvester strike, Respondent had four or five drivers who were willing to cross the International Harvester picket line[,] there appears to be no justification for the replacement of these two drivers. On the critical day of February 21, Respondent's schedule indicates that Andrus and Ciukaj could have been assigned to three other jobs or merely sent home for the day if no work was available. There would have been nothing unusual in either course of action[,] and

53. 700 F.2d 385 (7th Cir. 1983), denying enforcement to 259 N.L.R.B. 60 (1981). For a thoughtful critique of Browning-Ferris from the perspective of the wealth-maximization theory espoused by Judge Posner when he was an academic, see Case Comment, supra note 38 , at $584-90$.

54. Or so the court concluded; in fact, however, the adverse action in question was in the legally relevant sense a complete severance of the employment relation. Thus, invoking the well-settled policy that employees who are permanently replaced must make an "unconditional" offer to return to work in order to trigger reinstatement rights, see The Developing Labor Law, supra note 43 , at $230 \& \mathrm{n} .295$, the court asserted that Andrus and Ciukaj had not made such an offer because of their failure to promise to refrain from exercising their $\S 7$ rights upon rehire-that is, they had failed to "agre[e] to cross picket lines at premises of BFI's customers if necessary to enable BFI to fill those customers' orders." 700 F.2d at 389. Accordingly, in the court's view, the employer had no obligation to accord the drivers any reinstatement rights. See supra note 43 (discussing rights of individual who has been permanently replaced).

The court seems to have gotten it exactly wrong. True, the case law requires striking employees to forgo their economic demands in order to make a valid offer to return; that is what is meant by an unconditional offer. But prevailing doctrine does not require employees to renounce their $\$ 7$ rights as well. Indeed, it is the employer that is obliged not to condition its offer of reinstatement upon the relinquishment of statutory rights, not the reverse. See, e.g., Lindy's Food Center, 232 N.L.R.B. 1001, 1008 (1977) (employer may not condition offer to rehire returning strikers upon union's agreement to no-strike obligation); Albion Corp., 228 N.L.R.B. 1365, 1368 \& n. 14 (1977) (same), enforced in relevant part, $593 \mathrm{~F} .2 \mathrm{~d} 936$ (10th Cir. 1979). Were the rule otherwise, employees would be permitted to exercise their $\S 7$ rights-to strike or to refuse to cross a picket line, for example-exactly once per employer.

55. 259 N.L.R.B. at 67. 
Respondent offered no evidence to show that[,] by so doing, it would have adversely affected its business operation. Instead, Respondent chose to replace its two most senior drivers, which it clearly did not have to do. ${ }^{56}$

In sum, the Board skeptically examined the circumstances surrounding the challenged adverse action and concluded that they fell far short of making out the required showing of business necessity that would have justified the permanent replacement of Andrus and Ciukaj. ${ }^{57}$

On review, the court did not reject the Board's view of the facts; instead, it applied a quite different legal standard, in essence upholding the employer on the theory that permanent replacement of the refusing drivers ensured BFI "flexibility" in its business operations. 58 Rather than examining the circumstances BFI had actually faced, the court conjured up a parade of extrafactual horrors. First, the court noted that BFI had previously received an order from International Harvester that had required four trucks to fill and a second that would have required all six but was cancelled. The court reasoned:

BFI could reasonably anticipate receiving [another six-truck order] ... . in the future that would not be cancelled. Had BFI, while the strike was still on, received an order from International Harvester requiring only . . . five trucks to fill, it would not have been able to fill the order; it had only four drivers who were willing to cross the picket line. Moreover, it could not be sure that all four would be available for work every day-and if one was sick, and International Harvester required four trucks, as it had a few days before, BFI would not be able to fill the order. BFI could of course have used management personnel to drive the trucks, as it had done once before when the other drivers had balked at crossing the picket line, but a company is not required to use its managers to do work that its hourly employees refuse to do for reasons that though honorable are not the company's fault. BFI was entitled to hire permanent replacements to give itself flexibility in coping with fluctuations in a valued customer's demands and in its capacity to supply those demands. ${ }^{59}$

The point here is not that the court's concerns are unfounded; surely most employers would prefer to be able to count in advance upon their employees' services in the face of a picket line. It is rather

56. Id. (emphasis added).

57. Id.

58. 700 F.2d at 389 .

59. Id. (emphasis added). With respect to the court's assumption that BFI faced a realistic prospect of a second six-truck order from International Harvester, it sbould be noted that the earlier order of that magnitude had been cancelled because it had been placed by "mistake." 259 N.L.R.B. at 67 . With respect to the court's assertion that an employer is not obliged to have its managerial personnel perform struck work, it should be recalled that the Board's view is otherwise. See supra note 47 and accompanying text. 
that the opinion reveals a level of sensitivity to the employer's interests that departs widely from the strict business necessity standard applied by the Board.60

That the courts turn out to be more receptive to claims of employer prerogative than the Board is not unusual, but the argument here is that the disparity in this context is attributable in substantial part to a difference between the respective views of the Board and the courts on the nature and source of the employee rights that are at stake. As noted earlier, the Board's position is that the plain meaning of the Act protects an employee who honors a picket line, period. Such conduct is, in the Board's view, 'literally for 'mutual aid or protection,' as well as to assist a labor organization, within the meaning of Section 7."61 Moreover, the Board contends, the Act literally protects protesters who aid the employees of another employer as well as those who assist their own fellow workers. Thus, section 7 by its terms extends coverage of activities for the purpose of "mutual aid or protection" to all statutory "employees," 62 and a related provision expressly states that " $[t]$ he term 'employee' . . shall not be limited to the employees of a particular employer, unless [the Act] explicitly states otherwise "63

The courts, by contrast, are largely unconvinced by this literalism and almost invariably attempt to justify protection (or so much of it as

60. For a similar instance of this sort of striking disparity between the "businessnecessity" analyses of the Board and the reviewing court, see NLRB v. William S. Carroll, Inc., 578 F.2d 1, 5 (1st Cir. 1978), denying enforcement to 232 N.L.R.B. 1131, 1131 n.I, 1133-34 (1977); see also cases cited supra notes 51 \& 52.

61. Redwing Carriers, lnc., 137 N.L.R.B. 1545, 1546-47 (1962), aff'd sub nom. Teamsters Local 79 v. NLRB, 325 F.2d 1011 (D.C. Cir. 1963), cert. denied, 377 U.S. 905 (1964).

62. See 29 U.S.C. $\S 157$ (1982).

63. Id. § 152(3); see Business Servs. by Manpower, Inc., 272 N.L.R.B. 827, 827 (1984), enforcement denied, 784 F.2d 442 (2d Cir. 1986). The Supreme Court accepted this argument in an analogous context in Eastex, Inc. v. NLRB, 437 U.S. 556, 564-65 (1978) (discussed supra notes 17-26 and accompanying text), when it sustained the right of a union to circulate on company premises a newsletter addressing issues that were only remotely related to the subject employees' own terms and conditions of employment. In support of its holding, the Court stated that "the Board and the courts long have held that the 'mutual aid or protection' clause" encompasses "otherwise proper concerted activities in support of employees of employers other than their own[,]" and cited Redwing Carriers, 137 N.L.R.B. at 1546-47, and NLRB v. Alamo Express, Inc., 430 F.2d 1032, 1036 (5th Cir. 1970), cert. denied, 400 U.S. 1021 (1971)two cases recognizing a $\$ 7$ right to honor a stranger picket line-as authority. Eastex, 437 U.S. at 564-65 \& n.13. The Court added cryptically, however, that it "express[ed] no opinion ... . as to the correctness of the particular balance struck between employees' exercise of $\$ 7$ rights and employers' legitimate interests in any of the above-cited cases." Id. at 565 n.13. Redwing Carriers "struck" the "balance" for the employer and Alamo Express for the employee, and it is therefore not clear from the context which case-if, indeed, either-prompted the Court's cautious disclaimer. See generally Business Servs. by Manpower, 784 F.2d at 451-52 (analyzing siguificance of Eastex to stranger picket line context). 
they are willing to accord) on the basis of the refusing employees' selfinterest in the underlying protest. The First Circuit, for example, reversed the Board and upheld the discharge of a charter bus driver who refused to carry his charges across a picket line, noting that the protest in question was "aimed at a third party" and thus that the refusing driver's "interest in its success is more attenuated" than that of an employee who strikes to protest her own economic conditions. ${ }^{64}$ Similarly, the Second Circuit recently suggested that the section 7 interest in honoring a stranger picket line is "particularly weak" where it was simply a gesture of solidarity, with only a remote "possibility that the refusing employee will receive the benefit of similar support in the future." 65

Once again, the most striking example appears in Judge Posner's opinion in Browning-Ferris. ${ }^{66}$ The Board had served up its usual boilerplate, asserting its longstanding position that the refusal to cross a picket line was conduct protected by the Act. ${ }^{67}$ The court accepted the Board's holding in this respect, but in so doing stressed what it termed the "practical, nonideological self-interest" of BFI drivers Andrus and Ciukaj in supporting the protest at International Harvester. ${ }^{68}$ Thus, Judge Posner argued that the two "may have felt that strengthening the union movement by honoring a union's picket line would promote their own economic interests as workers."69 Acknowledging that Andrus and Ciukaj were not themselves represented by a union, Posner reasoned that they nevertheless

may have hoped to become members-hoped that a union victory at the International Harvester plant would encourage a successful organizing effort at their own plant. Or they may have believed that the union movement improves the working conditions of nonunion workers-that employers treat such workers better in order to ward off unionization. There is a third possibility. We do not know which workers were on strike at the International Harvester plant, but if they do the same type of work that BFI's drivers do[,] an increase in their wages or benefits through a successful strike might put competitive pressure on BFI to offer better terms to its drivers. ${ }^{70}$

With friends like this, protection for honoring stranger picket lines

64. Carroll, 578 F.2d at 4 n.3; see also NLRB v. C.K. Smith \& Co., 569 F.2d 162, 165 n.1 (1st Cir. 1977) (dictum suggesting that honoring stranger picket line is unprotected because the employees' "self-interest is not directly or indirectly implicated in the primary strike"), cert. denied, 436 U.S. 957 (1978).

65. Business Servs. by Manpower, 784 F.2d at 453.

66. NLRB v. Browning-Ferris Indus., 700 F.2d 385 (7th Cir. 1983), discussed supra notes 53-60 and accompanying text.

67. 259 N.L.R.B. 60, 66-67 (1981), enforcement denied, 700 F.2d 385 (7th Cir. 1983).

68. 700 F.2d at 387.

69. Id.

70. Id. 
hardly needs detractors. ${ }^{71}$ Given such thin justification, it is no wonder that the court ultimately struck the balance in favor of the employer's "flexibility" and upheld the permanent replacement of Andrus and Ciukaj. ${ }^{72}$

To be sure, the self-interest argument can be-and frequently isput in the more persuasive terms of the logic of collective action. As the Ninth Circuit has observed, "An integral part of any strike is persuading other employees to withhold their services and join in making the strike more effective," and thus " "respect for the integrity of the picket line may well be the source of strength of the whole collective bargaining process[,] in which every union member has a legitimate and protected economic interest." "73 Even here, however, the focus is on a self-interest that is indirect at best, and thus it is not surprising that the courts are frequently willing to reject section 7 claims on the basis of showings that are far less substantial than the business necessity required by the Board.

2. Fear and Loathing on the Picket Line. - A fascinating wrinkle on the primacy of protester self-interest can be found in the cases construing the protection available to an employee who honors a picket line for purely self-interested reasons-specifically, fear of retaliation by the picketers-rather than out of solidarity with the picketers' cause. As was the case with solidarity-inspired refusals, the Board invokes its reading of the plain language of the Act, asserting that employees who honor picket lines, whatever their reasons, are providing the picketers with the requisite "mutual aid or protection" and are, moreover, "assist[ing] ... a labor organization."74 That the employee is motivated by personal fear is deemed irrelevant, for-argues the Board-“" "the focal point of inquiry" " must be " "the nature of the activity itself rather than the employee's motives for engaging in the activity.' "75

71. Indeed, Judge Posner's opinion made an easy target for Judge Coffey, who started from the same premise of a requirement of self-interest, but came to a different conclusion:

[I]t defies logic to believe that the strike at International Harvester would provide any real long-term economic benefit to the BFI drivers. The notion that all workers benefit as a class if a sub-class obtains higher wages or better working conditions fails to provide a sufficient basis for a finding of "mutual aid." "Working class solidarity is at best a political slogan, not a viable economic theory."

Id. at $39 \mathrm{I}$ (Coffey, J., concurring in result) (citations omitted).

72. See supra notes 53-60 and accompanying text.

73. NLRB v. Southern Cal. Edison Co., 646 F.2d 1352, 1363-64 (9th Cir. 198I) (quoting NLRB v. Union Carbide Corp., 440 F.2d 54, 56 (4th Cir.), cert. denied, 404 U.S. 826 (1971)).

74. Cooper Thermometer Co., 154 N.L.R.B. 502, 504 (I965); see supra notes 61-63 and accompanying text.

75. Congoleum Indus., Inc., 197 N.L.R.B. 534, 547 (1972) (quoting Cooper Thermometer, 154 N.L.R.B. at 504); accord Dave Castellino \& Sons, 277 N.L.R.B. 453, 454 (1985); Ashtabula Forge, Div. of ABS Co., 269 N.L.R.B. 774, 774-75 (1984). 
Some courts, by contrast, are quite willing to undertake a motive inquiry; indeed, they see it as outcome-determinative. But the doctrine they apply takes an ironic twist: Whereas the solidarity-based refusal to cross a picket line was devalued as insufficiently self-interested, ${ }^{\mathbf{7 6}}$ these courts reject protection for the fear-based refusal because it is too selfinterested. As the Fourth Circuit argued in NLRB v. Union Carbide Corp. ${ }^{77}$ the seminal case on the issue,

One who refuses to cross a picket line by reason of physical fear does not act on principle. He makes no common cause, and contributes nothing to mutual aid or protection in the collective bargaining process. We hold, therefore, that [such a] refusal to cross the picket line was not protected under $\S 7.78$

The court has a point: Section 7 by its terms purports to apply only to activities that are undertaken "for the purpose of ... mutual aid or protection,"79 suggesting that employee motive or purpose should matter. But the Labor Board's reasons for eschewing inquiry into employee state-of-mind generally seem especially applicable here, where untangling the mix of solidarity, fear, and working-class habit may be a particularly difficult task. ${ }^{80}$ Moreover, it is not at all accurate to assert-as the court does in Union Carbide - that a fear-based refuser "contributes nothing to mutual aid or protection." 81 Whatever her motives, one who refuses to cross a picket line clearly "aid[s]" and "protect[s]" the picketers-and provides "assistance" to their "labor organization"- since this conduct is what makes the picket line work. ${ }^{82}$

76. See supra notes $64-73$ and accompanying text.

77. 440 F.2d 54 (4th Cir.), cert. denied, 404 U.S. 826 (1971).

78. Id. at 56. Accord G \& P Trucking Co. v. NLRB, 539 F.2d 705 (4th Cir. 1976) (table), denying enforcement to 216 N.L.R.B. 620 (1975). To be sure, most courts have honored the Union Carbide rule only in the breach, finding on the facts that the employee in question was acting on the basis of mixed-motives-for other-regarding as well as fear-based reasons. See, e.g., Coors Container Co. v. NLRB, 628 F.2d 1283, 1287-88 (10th Cir. 1980); Kellogg Co. v. NLRB, 457 F.2d 519, 526 (6th Cir.), cert. denied, 409 U.S. 850 (1972); Virginia Stage Lines, Inc. v. NLRB, 441 F.2d 499, 502 n.3 (4th Cir.), cert. denied, 404 U.S. 856 (1971); see also Lodges 743 and 1746, Machinists Union v. United Aircraft Corp., 534 F.2d 422, 445 n.39 (2d Cir. 1975) (dictum), cert. denied, 429 U.S. 825 (1976). The Sixth Circuit turned the rule on its head in Plain Dealer Publishing Co. v. Cleveland Typographical Union \# 53, 520 F.2d 1220, 1228-29 (6th Cir. 1975) (per curiam, adopting District Court opinion), cert. denied, 428 U.S. 909 (1976), suggesting that a fear-based refusal to cross picket line is not a "strike" and therefore does not violate a no-strike clause.

79. N.L.R.A. § 7, 29 U.S.C. § 157 (1982).

80. See supra note 29 and accompanying text.

81. 440 F.2d at 56.

82. It is tempting as well to quibble with the court's suggestion that actions motivated by a desire to avoid bodily harm are not "principle[d]." An entire tradition of philosophical theory has developed on the view that the security of the person is not only a principle-it is the principle. See T. Hobbes, Leviathan (M. Oakeshott ed. 1962); see also Hart, Positivism and the Separation of Law and Morals, 71 Harv. L. Rev. 593, 623 (1958) (noting connection between social construction of philosophical principles 
By contrast, the Union Carbide rule leaves the worker to negotiate a treacherously narrow passage between the Scylla of selflessness and the Charybdis of a self-interest that the courts will consider too personal. Possibly the courts that adopt this approach are simply "punishing the victim" in a frustrated effort to express disapproval for what they see as untoward conduct on picket lines. ${ }^{83}$ Or perhaps they do not particularly care for individuals who decline to cross picket lines, whatever their motives. ${ }^{84}$ But taken together, the two lines of cases seem to be animated by a common commitment to a narrow vision of worklife that confines employee protests to actions that further one's economic selfinterest-a vision that obscures both the more selfless and more complex, selfish concerns that also frequently prompt individuals to partici-

and human physical vulnerability); J. Atleson, supra note 4, at 208-09 n.40 (criticizing Union Carbide on similar grounds).

83. One's feelings about fear-based refusals may depend in large part upon one's attitude toward the picket line turbulence that frequently occasions them. The Board has traditionally been willing to give picketers a great deal of leeway here, making the courts squirm. Compare, e.g., Coronet Casuals, Inc., 207 N.L.R.B. 304, 304-05 (1973) (in the absence of actual violence, unlawfully discharged picketers do not lose their statutory right to reinstatement merely by "making abusive threats against nonstrikers") with NLRB v. W.C. McQuaide, Inc., 552 F.2d 519 , 527-28 (3d Cir. 1977) (mere verbal threats may warrant denial of reinstatement). This might explain why the courts draw the line at the point that the picketers' forceful behavior begins to have its desired effect, whereas the Board is willing to protect both the behavior and the would-be strikebreakers who are sensible enough to take the hint. The Reagan Board's contribution in this area rejects the traditional agency position and holds that mere verbal threats will remove a picketer from $\$ 7$ protection. See Clear Pine Mouldings, Inc., 268 N.L.R.B. 1044, 1046 (1984) (overruling Coronet Casuals), enforced, 756 F.2d 148 (9th Cir. 1985), cert. denied, 747 U.S. 1105 (1986).

Supporters of the Board's traditional position usually offer something of an "employees-are-animals" rationale; Board briefs routinely cite Milk Wagon Drivers Local 753 v. Meadowmoor Dairies, Inc., 312 U.S. 287 (1941), for the proposition that a "moment of animal exuberance" ought not render picket line conduct unprotected. Id. at 293. My own view, by contrast, is that the law should permit picketing employees as much room to protect their jobs as it accords the victim of, say, a home invasion. See generally Restatement (Second) of Torts $\$ 77$ (1965) (privileging the use of force that does "not threate[n] death or serious bodily harm" to protect one's land or chattels).

84. Although the conduct in question "smacks of the secondary boycott," $R$. Gorman, supra note 41 , at 322, the anti-secondary provisions of the Labor Act expressly exclude such refusals from their prohibitive sweep. See N.L.R.A \& 8(b)(4), 29 U.S.C. $\$ 158(b)(4)$ (1982). Nevertheless, the policy against secondary boycotts embodied in the Taft-Hartley and Landrum-Griffin amendments has surely had at least a heuristic effect upon decisions in this area. See, e.g., NLRB v. Browning-Ferris Indus., Chemical Servs., Inc., 700 F.2d 385, 391 (7th Cir. 1983) (concurring opinion); R. Gorman, supra note 41 , at 322 . Resistance to protection for those who honor picket lines may also be of a piece with the longstanding condemnation of "partial strikes." See id. at 322-23 ("the employee is violating the obligation in his employment contract to work according to his employer's directions, and is without authorization choosing, while on the payroll, not to make deliveries to or pickups from the picketed employer"). For an insightful account of why the courts would choose to vindicate this principle at the expense of the unambiguous language of $\S \S 7$ and 13 of the Act, see J. Atleson, supra note 4, at 44-66. 
pate in workplace protests. ${ }^{85}$

\section{I1. Seeking "Aid or Protection"}

Just as the Board and the courts confront the issue of protection for an employee who comes to the aid of another's cause, they are also faced with the opposite situation: the individual who seeks the support-real or symbolic-of her fellow workers in pressing her own claim. Not surprisingly, the Board and the courts use the "promise of reciprocal benefit" strategy in this context as well, and the requisite mutuality is found in the self-interest of those whom the individual calls to her aid, rather than in any more selfless concerns her colleagues' may have for her.

\section{A. Mutuality Redux}

$N L R B v . J$. Weingarten, Inc. ${ }^{86}$ provides the classic illustration of an employee seeking the aid of others. The case arose when an employer repeatedly denied an employee's requests for union assistance during questioning concerning alleged thefts from the workplace. The Board held that section 7 guarantees an employee the right to insist on the presence of a union representative at an interrogation that the employee reasonably believes might result in disciplinary action. ${ }^{87}$ Accordingly, the refusal of the employer to grant the employee's requests for a union representative-or, in the alternative, to cease the interrogation altogether-interfered with that right and was unlawful.88

Upholding the Board, the Supreme Court dismissed the argument that section 7 protection should be denied because the interrogated employee "alone may have an immediate stake in the outcome" of the investigation. 89 Once again citing Peter Cailler, the Court concluded that section 7 protected the request for representation and reasoned:

The union representative whose participation [the interro-

85. See generally J. Atleson, supra note 4, 67-83 (criticizing decisions that narrowly define employee interests worthy of legal protection).

86. 420 U.S. 251 (1975).

87. J. Weingarten, lnc., 202 N.L.R.B. 446, 449, enforcement denied, 485 F.2d 1135 (5th Cir. 1973), rev'd, 420 U.S. 251 (1975).

88. Id. at 450 . The alternative of halting the interrogation is not nearly so advantageous to the employer-nor bad for the employee-as it might appear at first blush. Thus, most collective-bargaining agreements permit employee discipline only upon a showing of "just cause" or its functional equivalent. See Bureau of Nat'l Affairs, Basic Patterns in Union Contracts 7 (11th ed. 1986) (finding "cause" or "just cause" provisions in $86 \%$ of the 400 collective-bargaining agreements studied). The failure of the employer to elicit the employee's side of the story may well constitute a fatal procedural infirmity in defending the resulting disciplinary action before an arbitrator. See $F$. Elkouri \& E. Elkouri, How Arbitration Works 673-75 (4th ed. 1985) (outlining "due process" requirements in discipline cases arising under contractual "just cause" guarantees).

89. 420 U.S. at 260. 
gated employee] seeks is . . safeguarding not only the particular employee's interest, but also the interests of the entire bargaining unit by exercising vigilance to make certain that the employer does not initiate or continue a practice of imposing punishment unjustly. The representative's presence is an assurance to other employees in the bargaining unit that they, too, can obtain his aid and protection if called upon to attend a like interview. 90

Thus, the Court concluded that the interests of the interrogated employee's fellow workers-the possibility of receiving similar support should they meet the same fate-provided the justification for guaranteeing union assistance to the target employee, but it agreed (or at least assumed) that the union could not be summoned to the aid of that employee for the latter's sake alone. ${ }^{91}$

The same phenomenon is apparent in the Supreme Court's decision in NLRB v. City Disposal Systems, Inc. ${ }^{92}$ In that case, truck driver James Brown was discharged for refusing to comply with his employer's order to drive a truck that was, in Brown's view, unreasonably dangerous. ${ }^{93}$ A provision in the governing collective-bargaining agreement arguably guaranteed employees the right to refuse to operate such ve-

90. Id. at 260-61 (footnote and citation omitted). The Court noted that " 'the entire hargaining unit" " had a particularly weighty interest in policing the "quantum of proof that the employer considers sufficient to support [a] disciplinary action.'" Id. at 261 n.6 (quoting Comment, Union Presence in Disciplinary Meetings, 41 U. Chi. L. Rev. 329,338 (1974)).

91. To be sure, once the Court concluded that $\S 7$ protected the target employee's request on the basis of the interests of others in the bargaining unit, it turned to a series of considerations that did focus upon the target employee's individual plight. Thus, the Court observed that the union representative's presence at the disciplinary interview might afford the lone employee "recourse to the safeguards the Act provide[s] "to redress the perceived imbalance of economic power between labor and management,'" facilitate fact-finding favorable to the employee at a point when the employer's mind is still open, and assist an employee who is "too fearful or inarticulate to relate accurately the incident being investigated, or too ignorant to raise extenuating factors." Id. at 261-64. Indeed, the Court suggested that even the employer's interest was an important factor in justifying the union presence, arguing that "[a] knowledgeable union representative could assist the employer by eliciting favorable facts, and save the employer production time by getting to the bottom of the incident occasioning the interview." Id. at 263. But the structure of the Court's opinion leaves no doubt about its view that the threshold issue was the service of the Weingarten right not to the target employee, but to tbe others in the bargaining unit.

92. 465 U.S. 822 (1984).

93. Two days before the incident leading to the discharge, Brown had observed a fellow employee having difficulty with the brakes on the trnck in question; indeed, as a result of that difficulty, the two had nearly collided. Id. at 826 . As it turned out, the employer had in the interim made the necessary repairs, but the Court evidently agreed that Brown "honestly and reasonably" believed that the trnck was still unsafe at the time he refused to drive it. Id. at 824,841 . But see id. at $826 \mathrm{n} .5$ (stating that the factual issue was not before the Court); City Disposal Sys., Inc. v. NLRB, 766 F.2d 969, 972-73 (6th $\mathrm{Cir}$. 1985) (on remand) (assuming that issue of Brown's "reasonable and honest belief" was still open and resolving it in Brown's favor). 
hicles.94 The principal issue before the Court was whether Brown's invocation of this contractual right constituted "concerted activit[y]" within the meaning of section 7,95 but the Court also addressed the question of whether his actions satisfied the mutuality requirement. As in Weingarten, the Court found the requisite mutuality on the basis of the interests of his fellow workers in the results of his protest. The Court explained that "a single employee's invocation of [contract] rights affects all the employees [who] are covered by the collective-bargaining agreement," and thus met "the 'mutual aid or protection' standard, regardless of whether the employee has his own interests most immediately in mind."96 The passage cited only Weingarten, ${ }^{97}$ leaving no doubt that the "interest" of the others at stake was the "assurance ... that they, too, can obtain [such] aid and protection" if confronted with a work order reasonably appearing to violate their collective contract. ${ }^{98}$

\section{B. The Devaluation of the Other: The Contours of Weingarten}

The protesting employees in Weingarten and City Disposal-like those in Hendricks and Eastex-were ultimately accorded the protection of section 7. Indeed, in contrast to Hendricks and Eastex, the factual assumption invoked-that, in the workplace setting, "an injury to one is an injury to all"-is quite sensible. But once again, the Peter Cailler strategy has its costs. Recourse to the "promise of reciprocal benefit"

94. The contract stated in pertinent part:

The Employer shall not require employees to take out on the streets or highways any vehicle that is not in safe operating condition or equipped with the safety appliances prescribed by law. It shall not be a violation of [the no-strike clause of] this Agreement where employees refuse to operate such equipment unless such refusal is unjustified.

465 U.S. at 824-25 (quoting parties' appendix).

95. See N.L.R.A. $\S 7,29$ U.S.C. $\$ 157$ (1982) (restricting statutory protection to "concerted activities for the purpose of ... mutual aid or protection") (emphasis added). The Court answered the question in the affirmative, sustaining the Board's so-called Interboro doctrine, which deems "concerted" an individual employee's "reasonable and honest invocation of a right provided for in his collective-bargaining agreement." 465 U.S. at 841 . The issue of "concert" and the Interboro doctrine in particular are discussed at infra notes $129-83$ and accompanying text.

96. 465 U.S at 830 .

97. Id.

98. Weingarten, 420 U.S. at 260-61 (citing NLRB v. Peter Cailler Kholer Swiss Chocolates Co., 130 F.2d 503, 505-06 (2d Cir. 1942)); see City Disposal, 465 U.S. at 830. For other opinions that invoke the interpretive strategy evident in Weingarten and City Disposal, see, e.g., Bechtel Power Corp., 277 N.L.R.B. 882, 884 (1985) (extending § 7 protection to employee making safety complaint pursuant to provision of collective-bargaining agreement because employee was "acting not only in his own interest, but [was] attempting to enforce that contract provision in the interest of all the employees covered by the contract") (citing City Disposal); Brown \& Janower, 218 N.L.R.B. 540, 546-47 (1975) (employee seeking assistance of fellow worker to protest former's wage rate), enforced, 546 F.2d 690 (6th Cir. 1976). 
has had a significant influence upon the manner in which the Labor Board and the courts have shaped the contours of such section 7 rights. Thus, to cite one example, the Board has held that the Weingarten right belongs to the union rather than to individual unit employees; it can thus be waived and sold to the employer through the collective-bargaining agreement. ${ }^{99} \mathrm{Had}$ the Board focused upon the interrogated employee's "immediate stake in the outcome of the interview" and upon her own relationship to the bargaining representative, the case might well have come out the other way. ${ }^{100}$ The agency acknowledged those interests, but-quoting Weingarten's argument that the representative "safeguard[s] 'not only the particular employee's interest, but also the interests of the entire bargaining unit" "-it stressed instead the union's "important stake in the process" and thus concluded that the right was the union's to waive. ${ }^{101}$

An even more striking example can be found in the Board's recent decision in E.I. duPont de Nemours, ${ }^{102}$ which rejected Weingarten rights for employees who are not represented by a union. In that case, a company official sought to interrogate employee Walter Slaughter with respect to the latter's attempt to post at the plant an unauthorized notice announcing a union representation election. Slaughter secured the agreement of two co-employees to act as his witnesses and insisted upon their presence at the investigatory session. The company official, for his part, refused to meet with Slaughter under those conditions and

99. Prudential Ins. Co., 275 N.L.R.B. 208, 209 (1985), on remand from 661 F.2d 398 (5th Cir. 1981), denying enforcement to 251 N.L.R.B. 1591 (1980). In its earlier decision, the Board had avoided the legal issue by concluding on the facts that the union had not waived the Weingarten right. 251 N.L.R.B. at 1592. The Fifth Circuit reversed, finding a waiver and holding that it was permissible under the Act. 661 F.2d at 400-01.

100. The typologies that current doctrine provides to determine whether a waiver of statutory rights is permissible are not particularly well-suited to this context. Thus, the Weingarten right does not easily fit into either the category of so-called "economic" rights, which can be waived, see, e.g., NLRB v. Sands Mfg. Co., 306 U.S. 332, 342 (1939) (right to strike for better terms and conditions of employment during term of collectivebargaining agreement), or that of representation-reinforcing rights, which cannot, see, e.g., NLRB v. Magnavox Co., 415 U.S 322, 324 (1974) (right to distribute union campaign literature on plant premises). See generally Metropolitan Edison Co. v. NLRB, 460 U.S. 693, 705-07 (1983) (discussing difference between economic and representation-reinforcing rights). Arguably, however, the Weingarten right is closer in spirit to the latter, since it directly implicates the relationship between the employee and her bargaining representative.

101. Prudential Ins. Co., 275 N.L.R.B. at 209 \& n.13 (quoting Weingarten, 420 U.S. at 260). 1 do not mean to suggest that this is an altogether unsalutary result; surely unions should be given some leeway in allocating scarce resources among their various representational activities. That, however, would seem to be a matter more appropriately handled between a union and its members, rather than by permitting the employer to punish for insubordination the employee who asserts her Weingarten right.

102. 289 N.L.R.B. No. 81, 128 L.R.R.M. (BNA) 1233 (June 30, 1988). The procedural history of the case is not easy to express in citation form; it is set forth in narrative infra note 104. 
fired him for "insubordination."103

The Board upheld the discharge and concluded that Slaughter, as a nonunion employee, was not entitled to the protection of Weingarten. ${ }^{104}$ Citing Peter Cailler-and the passage in Weingarten that itself had relied on that case-the Board reasoned that the requisite "mutual[ity]" might be found in "an implicit promise that the employee enlisting support would offer his own support were the other facing such an interview." 105 The Board ostensibly rejected this argument in favor of a "balanc[ing]" of employer and employee interests, ultimately striking that balance in favor of the employer. ${ }^{106}$ But the Board's evaluation of the stakes on the employee side of the equation was strongly influenced by its understanding that the section 7 right was ultimately grounded not in the interests of Slaughter, but in those of the other employees. ${ }^{107}$

Thus, the Board noted that the principal rationale for according Weingarten rights in the union setting was their beneficial effect upon

103. 128 L.R.R.M. (BNA) at 1233-34.

104. In Materials Research Corp., 262 N.L.R.B. 1010 (1982), the Board had held that Weingarten did apply in the nonunion context. Relying on Materials Research, the Board issued its original decision in $d u P o n t$ and condemned Slaughter's discharge as an unfair labor practice. 262 N.L.R.B. 1028 (1982). The Third Circuit enforced the Board's order, 724 F.2d 1061 (3rd Cir. 1983), but, at the Board's subsequent request, vacated that decision and remanded the case to the agency, 733 F.2d 296 (3d Cir. 1984).

The Board's unusual action was apparently prompted by an intervening change in personnel. By late I983, Reagan appointees constituted a three-vote majority (Chair Dotson and Members Hunter and Dennis-Diaz) of the five-member Board and had evidently decided by this time to reconsider Materials Research. Indeed, while duPont was still pending, the Board issued Sears, Roebuck \& Co., 274 N.L.R.B. 230 (1985), in which it concluded that nonunion employees do not, after all, enjoy the Weingarten right. No doubt seeking to enshrine its wisdom for the ages, the majority went so far as to suggest that this conclusion was "compel[led]" by the Act and that the Materials Research rule was an impermissible interpretation. Id. at $230 \& \mathrm{n} .5$. The Board thereupon issued a supplemental decision in duPont, in which it relied on Sears and rejected Slaughter's challenge to his discharge. 274 N.L.R.B. 1104, 1104 (1985).

The Third Circuit, which had already declared Materials Research consistent with the Act, was predictably unimpressed by the Board's contrary conclusion in duPont. Slaughter v. NLRB, 794 F.2d 120 (3rd Cir. 1986). (The Board's new position was not, however, without its judicial supporters. See E.I. DuPont de Nemours and Co. v. NLRB, 707 F.2d 1076, 1079 (9th Cir. 1983).) In any event, the Third Circuit remanded duPont to the agency once again. 794 F.2d at 128 . On remand, in the opinion discussed in the text, the Board reaffirmed its holding in Sears that nonunion employees have no Weingarten rights, but admitted that this was merely a "permissible"- rather than a "compelled"-construction of the Act. 128 L.R.R.M. (BNA) at 1234 \& n.8, 1236. This is not to say that the reasons it offered in support of this determination were much more persuasive than the ones given in Sears, see infra note 111 .

105. 128 L.R.R.M. (BNA) at 1234.

106. Id. Ironically, given its traditional deployment of a literal interpretation of $\S 7$ in other contexts, see supra text accompanying notes $61-63 \& 74-75$, the Board characterized the Peter Cailler approach it purported to reject as a "plain language" interpretation of the provision. 128 L.R.R.M. (BNA) at 1234.

107. 128 L.R.R.M. (BNA) at 1235. 
" 'the entire bargaining unit." "108 In the absence of union representation and its attendant legal constraints and empowerments, however, no such benefit to other employees could be counted on.

[I]n a nonunion setting there is no guarantee that the interests of the employees as a group would be safeguarded by the presence of a fellow employee at an investigatory interview. Unlike a union steward (or his proxy), a fellow employee in a nonunionized work force has no obligation to represent the interests of the entire bargaining unit. Furthermore, an employee in a nonunion work force would be much less able than a union representative to "exercis[e] vigilance to make certain that the employer does not initiate or continue a practice of imposing punishment unjustly," as it is unlikely that such an employee would have the benefit of a framework similar to that typically established in a collective-bargaining agreement in which acts amounting to misconduct and means of dealing with them are defined. Nor would an employee in a nonunion setting be likely to have access to information as to how other employees had been dealt with in similar circumstances; whereas a union representative would typically be entitled to information from which it could be determined whether the employer was maintaining consistency and fairness in discipline. ${ }^{109}$

In sum, the Board declined to recognize a Weingarten right in the nonunion context because the law would neither require the assisting employees to "safeguard" the "interests of the employees as a group" (rather than simply those of the interrogated employee), nor afford them the advantages enjoyed by union representatives that would enable them to do so effectively (for example, the employer's duty to furnish information). ${ }^{110}$ It was therefore not enough that Slaughter's fellow employees were willing to come to his aid and support, since the law would neither force nor enable them to represent their own interests as well.111

108. Id. (quoting Weingarten, 420 U.S. at $260-61$ ).

109. 1d. (footnotes omitted) (emphasis added).

110. It should nevertheless be noted that the Board strongly suggested that it would strike a different "balance" in the case of a nonunion employee who was disciplined for merely requesting the presence of a colleague at a disciplinary interview, rather than insisting upon such assistance to the point of refusing otherwise to participate in the interrogation. Id. at 1236 n.15.

111. The Board offered three other reasons for rejecting Weingarten in the nonunion context, which together illustrate the truth of Professor Black's lovely dictum that "[ $[$ ]he curves of callousness and stupidity intersect at their respective maxima." Black, The Lawfulness of the Segregation Decisions, 69 Yale L.J. 421 , 422 n.8 (1960). First, the Board suggested that it was unlikely that an employee called upon to assist a colleague in the nonunion context would have the skills and expertise of a union steward, who could assist a "fearful" and "inarticulate" employee. 128 L.R.R.M. (BNA) at 1235 (citing Weingarten, 420 U.S. at 263). Putting aside the obvious objection that the Board has overstated the prowess of the average shop steward while underestimating the talent and resolve of the rank-and-file, surely employees can determine for themselves whether 


\section{Beyond The "Mutuality" Requirement}

The phenomena explored thus far-the rejection of solidarity as a legitimate motive for joining protest activity and the corresponding treatment of the individual whose personal claim is at stake as a mere means to his colleagues' self-interested ends-are evident as well in a host of contexts outside of the interpretation and application of the mutuality requirement and indeed ouside of section 7 itself. This sug-

the assistance they seek from their coworkers will be fruitful. In this case, for example, employee Slaughter sought witnesses and moral support, not professional representation; that he had no guarantee of the latter is hardly a reason to deny him the former.

The Board further observed that an employer faced with the invocation of the Weingarten right is free, under current Board doctrine, to decide not to conduct a disciplinary interview at all. See Weingarten, 420 U.S. at 258. In the union context, the Board reasoned, the gravity of this risk for an employee is diminished because she can virtually always present her side of the story at other, more advanced stages of the grievanceresolution process. 128 L.R.R.M. (BNA) at 1236; see also supra note 88 (noting that employer who disciplines his employee without hearing her version of the events in question may run into "due process" difficulties in arbitration). By contrast, the Board opined, the nonunion employee whose employer dispenses with the disciplinary interview might never be afforded the chance to present her case, and therefore "there is a serious question whether extending the right to nonunion employees may not work as much to their disadvantage as to their advantage." 128 L.R.R.M. (BNA) at 1236. But again, the Board's paternalism is unwarranted; the employee can decide for herself whether to run this risk of insisting upon the presence of a coworker. Furthermore, it is not at all clear that the appropriate remedy is to extinguish the nonunion employee's Weingarten right, rather than simply to eliminate the employer's option of refusing to conduct the interview because the target employee has chosen to invoke the protection of $\& 7$.

Finally, the Board observed that the presence of a union steward at a disciplinary interview is " a factor conducive to the avoidance of formal grievances through the medium of discussion and persuasion conducted at the threshold of an impending grievance.' " Id. at 1235 (quoting Weingarten, 420 U.S. at 262 n.7) (citation omitted). And in the absence of a union, argued the Board, this benefit disappears, since "there typically is no enforceable grievance procedure through which the employee could seek further recourse and thus no question arises of discouraging the filing of grievances ...." Id. at 1236.

At first blush, the Board's logic seems downright Orwellian: Since unrepresented employees do not enjoy contractual protection against employer arbitrariness, why not deny them statutory protection as well? But the Board has a point. Confining employee rights to the instrumental role of promoting industrial peace has a long tradition in American labor law; witness Justice Marshall's famous dictum that $\S 7$ rights are "protected not for their own sake but as an instrument of the national labor policy of minimizing industrial strife 'by encouraging the practice and procedure of collective bargaining.'" Emporium Capwell Co. v. Western Addition Community Org., 420 U.S. 50,62 (1975) (citation omitted). Of course, "minimizing industrial strife" is only one "national labor policy" that judges, Board members, and labor lawyers routinely invoke to sell their wares; redressing "the perceived imbalance of economic power between labor and management" is its paternal twin and frequently points the other way. See, e.g., Weingarten, 420 U.S. at 262 . That latter goal would surely be furthered more by according Weingarten rights to the unrepresented than it was by recognizing them for those who already enjoy the benefits of a union contract and binding arbitration. Thus unexplained is why the Board chose the one policy at the expense of the other in duPont. 
gests that the extensive use of the "promise of reciprocal benefit" strategy may be attributable to more than Peter Cailler's age, pedigree, and ingenuity. The imagery it invokes appears to reflect a broader commitment in labor law to a regime of self-interest between and among employees.

\section{A. Self/Others in Other Section 7 Contexts}

1. Unfair Labor Practice Protection for Confidential Secretaries. - The resistance to solidarity-based protests is apparent in the debate over the Board's longstanding and much criticized treatment of "confidential employees." Once again the Board takes the position that the support that such individuals render others is literally protected by the Act, and once again the courts resist section 7 protection on the ground that confidentials lack any self-interest in the union or other protest activities of their colleagues.

The Board excludes confidentials-primarily secretaries who act in a confidential capacity to an employer's labor-relations policy makersfrom Board-certified bargaining units, making union representation for them highly unlikely. ${ }^{112}$ The Board's rationale for this exclusionary policy is straightforward: Confidential employees might otherwise be tempted to disclose prematurely management's collective-bargaining and grievance handling strategies to their fellow workers. ${ }^{13}$ Apart from the bargaining-unit exclusion, however, the Board generally accords confidentials section 7 protection against unfair labor practicesto take the pertinent (and most common) example, against employer retaliation for participating in workplace protests supporting fellow employees who do not "enjoy" confidential status. ${ }^{114}$ The Board justifies this protective policy in much the same way it defends protection for employees who honor picket lines: by pointing to the "plain meaning" of the Act. Confidentials, the Board argues, are "employees" under section 2(3) and thus entitled to unfair-labor-practice protection like

112. The Act does not by its terms exclude confidential employees from its definition of covered "employee[s]." See N.L.R.A. § 2(3), 29 U.S.C. § 152(3) (1982). Rather, the Board developed the exclusionary rule as a matter of labor policy in the late 1930's, see, e.g., Brooklyn Daily Eagle, 13 N.L.R.B. 974, 986 (1939), and refined it over the years to encompass only those "who assist and act in a confidential capacity to persons who formulate, determine, and effectuate management policies in the field of labor relations." B.F. Goodrich Co., 115 N.L.R.B. 722,724 (1956). In NLRB v. Hendricks County Rural Elec. Membership Corp., 454 U.S. 170, 189-90 (1981)—discussed at supra notes 10-16 and accompanying text-the Supreme Court approved this narrow "labor-nexus" definition of confidential employees.

113. See, e.g., Hoover Co., 55 N.L.R.B. 1321, 1323 (1944).

114. See, e.g., Hendricks County Rural Elec. Membership Corp., 236 N.L.R.B. $1616,1617-21$ (1978) (signing petition in support of disabled rank-and-file employee), ordered enforced, 454 U.S. 170 (1981); Wheeling Elec. Co., 182 N.L.R.B. 218, 220 (1970) (refusal to cross rank-and-file picket line), enforcement denied, 444 F.2d 783 (4th Cir. 1971). 
any other statutory employee. ${ }^{115}$

Judicial critics argue that this "half-a-loaf" treatment-excluding confidentials from bargaining units but protecting them under section 7 -is irrational. The most thoroughgoing expression of this critique was articulated by Judge Craven of the Fourth Circuit in NLRB $v$. Wheeling Electric Co., ${ }^{116}$ which denied enforcement to a Board order reinstating Imogene McConnell, a confidential secretary who had refused to cross the rank-and-file's picket line.

It strikes us as nonsense for the Board to exclude Mrs. McConnell from membership in the bargaining unit and then extend to her the same protection for the same concerted activity that she would have enjoyed if a union member. If Mrs. McConnell is committed to the union cause to the extent she

115. See, e.g., Peavey Co., 249 N.L.R.B. 853, 853 n.3 (1980), enforced, 648 F.2d 460 (7th Cir. 1981); Wheeling Electric, 182 N.L.R.B. at 218 n.1, 220-21. There is something to the Board's argument. Section 2(3) of the Act, 29 U.S.C. $\& 152(3)$, states that "[t]he term 'employee' shall include any employee ... unless [the Act] explicitly states otherwise" and proceeds to list several categories-like supervisors and independent contractors-for exclusion. As the Board noted in Wheeling Electric, "the failure of the Act explicitly to state that confidentials are not employees" certainly suggests that Congress did not intend to exclude them. 182 N.L.R.B. at 218 n.1.

That argument had little success in an analogous context. See NLRB v. Bell Aerospace Co., Div. of Textron, lnc., 416 U.S. 267, 274-90 (1974) ("managerial employees" who lack labor-relations responsibilities are nevertheless outside the Act, notwithstanding the failure of Congress to list them among the categories excluded from $\S 2(3)$ ). But see Hendricks, 454 U.S. at 178-88 (seemingly rejecting Bell Aerospace's conclusion that Congress intended to exclude individuals who lack labor-relations responsibilities from the Act). Moreover, it provides tenuous support for the Board policy under discussion here. After all, the provision in the Act that deals with the make-up of bargaining units expressly enjoins the Board to "assure to employees the fullest freedom in exercising the [bargaining] rights guaranteed by [the Act]." Section 9(b), 29 U.S.C. $\$ 159(\mathrm{~b})$. Unexplained is why the "confidentials-are-employees" argument that supports protection under $\S 7$ nonetheless permits exclusion under $\S 9(\mathrm{~b})$.

But whatever the Board's plain language explanation lacks in persuasive force, it makes up for in longevity. Like its practice of excluding confidentials from bargaining units, the Board adopted this protective policy in the earliest years of the Act. See, e.g., Southern Colo. Power Co., 13 N.L.R.B. 699, 710 (1939), enforced, 111 F.2d 539 (10th Cir. 1940). And it has adhered to it ever since. See, e.g., Intermountain Rural Elec. Ass'n, 253 N.L.R.B. 1153, 1165-66 n.20 (1981), remanded in part on other grounds, 732 F.2d 754, 760-62 (10th Cir. 1984), cert. denied, 469 U.S. 932 (1984) (employer petition), on remand, 277 N.L.R.B. 1 (1985)); see also Hendricks, 454 U.S. at 185-86 n.19 (noting the protective policy, but finding it unnecessary to pass upon its validity).

In the mid-1980s, there were intimations that the policy might be reconsidered. See Lucky Stores, Inc., 269 N.L.R.B. 942, 944-45 (1984); Emanuel Lutheran Charity Bd., 268 N.L.R.B. 1344, 1347 (1984). See generally supra note 31 (describing reversals of Board policy under Chair Dotson). The Board's more recent pronouncements, however, are more equivocal and suggest that it is not inclined to revisit the issue at this time. See Crest Mark Packing Co., 283 N.L.R.B. No. 151, 125 L.R.R.M. (BNA) 1139, 1140 (May 18, 1987); Local No. 980, Automobile, Aerospace \& Agricultural Implement Workers of America, 280 N.L.R.B. No. 161, 124 L.R.R.M. (BNA) 1102, 1103 (July 31, 1986); Intermountain Rural Elec. Co., 277 N.L.R.B. 1,5 n.18 (1985).

116. 444 F.2d 783 (4th Cir. 1971). 
joins the strike by refusing to cross the picket line, it would seem to matter little to the company that she is not technically a union member. A confidential secretary who plights her troth with the union differs in form, but not in substance, from one who holds a union card. Since she cannot formally join the unit, there is nothing incongruous in holding that she cannot "plight her troth" with the unit. Indeed, it seems more consistent to say that if she cannot act in concert by participating in the unit, then she cannot act in concert on an informal basis, or more accurately, that if she does so, it will be without the protection of the Act. 117

Why, it is fair to ask, is it "nonsense" for the Board to conclude that the policy issues raised by the question of unit inclusion for confidentials differ significantly from those raised by the question of section 7 protection? It is not at all clear, for example, that the solicitude for management's strategic labor confidences that drives the unit-exclusion policy has much relevance in the context of a confidential secretary who simply refuses to cross the rank-and-file's picket line (as was the case in Wheeling Electric)-let alone in the case of one who joins her colleagues in signing a petition protesting the dismissal of a fellow employee (as in Hendricks). ${ }^{118}$ Moreover, the legislative history of the TaftHartley amendments suggests that Congress accepted the Board's practices with regard to confidentials, or was at least not inclined to

117. Id. at 788. Accord Peerless of Am., Inc. v. NLRB, 484 F.2d 1108, 1112 (7th Cir. 1973). The Supreme Court avoided this issue in Hendricks, where the employer had contended that Mary Weatherman-the employee discharged for signing the petition calling for the reinstatement of a disabled colleague-was a confidential secretary and therefore excluded from $\$ 7$ protection. The Board had rejected both the premise that confidentials are excluded from the coverage of $\$ 7$ and the employer's related contention that Weatherman's access to confidential information that did not involve labor matters made her a confidential employee for the purposes of the Act. 236 N.L.R.B. at 1619-21. The Court in Hendricks addressed the latter issue and sustained the Board's "labor-nexus" definition of confidential employees. 454 U.S. at 190. It therefore accepted the Board's factual determination that Weatherman was not a confidential, id. at $190-91$, and thus found it unnecessary to reach the question whether individuals who are properly classified as confidentials are protected by $\S 7$, id. at $185 \mathrm{n} .19$.

Justice Powell-writing for himself, Chief Justice Burger, and Justices Rehnquist and $O^{\prime}$ Connor-did address the issue and concluded that confidentials should be excluded from $\S 7$ 's coverage, quoting with approval the passage in text from Wheeling Eleciric. Id. at 197-200 (Powell, J., concurring in part and dissenting in part).

118. The employer is, after all, free to fire her if she discloses its labor secrets to other employees - or even, under prevailing doctrine, if the employer has merely " $a$ more than conjectural suspicion" that she might do so. See, e.g., Lucky Slores, 269 N.L.R.B. at 942 n.2, 945-46 (noting, however, that discharge would be unlawful if it was motivated by opposition to employee's participation in $\S 7$ activities rather than desire to protect integrity of employer's confidences). Indeed, the employer is generally given a freer reign in his dealings with a confidential than would be the case with a rank-andfile employee. See, e.g., American Book-Stratford Press, Inc., 80 N.L.R.B. 914, 915 (1948) (employer may question confidential secretary about union membership to determine whether he wishes to retain her in a confidential capacity). 
disturb them "in any respect."119 Indeed, Congress adopted a similar approach with respect to plant guards-another class of employees whose membership in rank-and-file bargaining units might well create some conflict of interest in the performance of their duties (as, for example, in the context of a violent strike). During the Taft-Hartley debates, Congress rejected a House bill that would have excluded guards from the Act altogether; ${ }^{120}$ it adopted in its stead a provision that accords them full protection under section 7, but excludes them from membership in rank-and-file unions. ${ }^{121}$ This, of course, is much like the "half-a-loaf" treatment that the Board accords confidentials. ${ }^{122}$

The argument that the Board's policy is "nonsense" seems to rest on the now familiar assumption that an employee can have no legitimate statutory interest in supporting a protest undertaken by her fellow workers unless she is in a position to reap directly the benefits of her colleagues' efforts. This view seems to be borne out by NLRB v. Bel-Air Mart, Inc., ${ }^{123}$ a Fourth Circuit case decided shortly after Wheeling Electric and also authored by Judge Craven. In Bel-Air Mart, the court was forced to confront the question whether it was "nonsense" for plant guards to be excluded from rank-and-file bargaining units and at the same time to enjoy section 7 protection for supporting the union activities of their rank-and-file colleagues. After carefully reviewing the relevant legislative history, the court concluded that the congressional

119. H.R. Conf. Rep. No. 510, 80th Cong., 1st Sess. 35 (1947), reprinted in 1 NLRB Legislative History of the Labor Management Relations Act, 1947, at 539-40 (1948) [hereinafter Legis. Hist. 1947]; see also infra note 122 (discussing report in greater detail).

120. See H.R. 3020, 80th Cong., 1st Sess. §§ 2(3), 2(12)(B), reprinted in 1 Legis. Hist. 1947, supra note 119 , at $34-35,40-41$.

121. N.L.R.A. §9(b)(3), 29 U.S.C. § 159(b)(3) (1982); see H.R. Conf. Rep. No. 510, 80th Cong., 1st Sess. 35-36, reprinted in 1 Legis. Hist. 1947, supra note 119, at $539-40$.

122. To be sure, the congressional intention with respect to confidentials-whom the House bill would also have excluded from the Act, see H.R. 3020, 80th Cong., 1st Sess. $\S \S 2(3), 2(12)(C)$, reprinted in 1 Legis. Hist. 1947, supra note 119, at 34-35, 40-41-is somewhat more ambiguous. On the one hand, Congress ultimately rejected the exclusionary provision in their case altogether. See H.R. Conf. Rep. No. 510, 80th Cong., 1st Sess. 35, reprinted in 1 Legis. Hist. 1947, supra note 119, at 539. At the same time, however, the conference report states that the House managers acquiesced in this on the view that "prevailing Board practice" already treated such employees as "outside the Act." Id. The majority in Hendricks suggested that the report in question may have simply used the expression "outside the Act" as an "imprecise shorthand" for the Board's actual practice-an interpretation that is buttressed by an earlier report, which indicated that House members were aware that the Board's practice was simply to exclude confidentials from bargaining units. NLRB v. Hendricks County Rural Elec. Membership Corp., 454 U.S. 170, 185 n.19 (1981); see H.R. Rep. No. 245, 80th Cong., 1st Sess. 23 (I947), reprinted in 1 Legis. Hist. 1947, supra note 119, at 314 ("[t]he Board ... normally excludes from bargaining units confidential clerks and secretaries to [executives]") (emphasis added).

I23. 497 F.2d 322 (4th Cir. 1974). 
intention to permit such a "half-a-loaf" approach was unmistakable. ${ }^{124}$ Somewhat sheepishly, the court continued:

Despite this holding, we cannot fail to recognize the incongruous result which, in part, led us to an opposite conclusion with respect to the confidential secretary in Wheeling Electric. We said:

1t strikes us as nonsense for the Board to exclude Mrs. McConnell from membership in the bargaining unit and then extend to her the same protection for the same concerted activity that she would have enjoyed if a union member. ${ }^{125}$

The court went on to argue that section 7 protection for the excluded guard served a statutory objective that would not be furthered by extending similar protection to confidential secretaries. Thus, the court asserted that legal protection for the gnard

serves a very limited purpose. The right of the guard which we here protect has little practical value aside from the rare instance when an employer voluntarily chooses to bargain with a union [representing both guards and rank-and-file employees,] which could not be certified, or where attendance at the meeting "educates" the gnard to the benefits of unionism, though such benefits are later obtained only by membership in a separate, certifiable union. ${ }^{126}$

By contrast, a confidential secretary is not entitled to legally protected membership "in a separate, certifiable union."127 Accordingly, the court concluded, "no benefits could flow to her" from her support of the rank-and-file's cause; "her section 7 rights, if they existed, were valueless to her." 128

124. Id. at 325-28. On the legislative history of the Act's treatment of plant guards, see supra notes 120-21 and accompanying text.

125. 497 F.2d at 328 (footnote omitted).

126. Id. (citations omitted).

127. Id. See Hoover Co., 55 N.L.R.B. 1321, 1322-23 (1944); NLRB v. Hendricks County Elec. Membership Corp., 454 U.S. 170, 178 n.10 (1981).

128. Bel-Air Mart, 497 F.2d at 328 n.13. The court assumed that the secretary "could under no circumstances be a member of the same bargaining unit as the employees whose picket line she refused to cross." Id. In this the court was not entirely correct. Nothing in Board decisions or in the Act would prevent an employer and a union from voluntarily deciding to include confidentials in a bargaining unit and accordingly to bargain collectively with respect to their rights and responsibilities. Cf. H.R. Rep. No. 245, 80th Cong., 1st Sess. 17 (1947), reprinted in 1 Legis. Hist. 1947, supra note 119, at 308 (explaining that even the express statutory exclusion for supervisors "does not forbid anyone to organize. It does not forbid any employer to recognize a union of foremen. Employers who, in the past, have bargained collectively with supervisors may continue to do so.").

But the court was quite right in its essential point that the predicament of the gnard and of the confidential "are not precisely the same." 497 F.2d at 328 n.13. Guards are entitled to legally enforceable bargaining rights-albeit in separate unions-under the Act; confidentials are not accorded bargaining rights in any circumstances, see supra note 127 and accompanying text. 
Again, then, we see the judicial view that section 7 protection turns upon the self-interest of those who would join a protest. By contrast, the right to act out of solidarity with one's fellow workers-without paying for it with one's job-is deemed "valueless."

2. The Requirement of "Concert."

a. The Doctrinal Background. - The treatment of the individual whose personal claim is at stake as merely a means to her colleagues' self-interested ends is evident in the cases involving an employee who presses her claim against the employer, but who does not attempt to enlist the support of her fellow workers in so doing. The classic example here is City Disposal, in which employee Brown refused his employer's order to drive a truck he thought to be unsafe. ${ }^{129}$ The problem is that such individual conduct is arguably not "concerted activit[y] for the purpose of . . mutual aid or protection" and thus not within the language of section 7.130 The current state of the law of concert is somewhat confused. The confusion stems-once againfrom two competing interpretive strategies that have emerged over the years, one developed for the most part by the Board and the other by the reviewing courts. To complicate matters further, the agency and the courts have each recently reversed field and adopted the other's position on this issue. ${ }^{131}$

One strategy-originally developed by the courts of appeals, but now generally associated with the Reagan Board's decisions in Meyers Industries, Inc. ${ }^{132}$ and Darling, Inc. ${ }^{133}$-embraces the literal meaning of the expression "concerted activities."134 Taken to its logical extreme, this strategy would deny protection to any conduct not collectively undertaken by at least two employees. ${ }^{135}$ But the Meyers approach teeters

129. NLRB v. City Disposal Sys., Inc., 465 U.S. 822 (1984), discussed supra notes 92-98 and accompanying text.

130. 29 U.S.C. $\$ 157$ (1982) (emphasis added).

131. See infra note 157 .

132. 268 N.L.R.B. 493 (1984) (Meyers $I$, remanded sub nom. Prill v. NLRB, 755 F.2d 941 (D.C. Cir.) (Prill $I$ ), cert. denied, 474 U.S. 948 (1985), on remand, 281 N.L.R.B. No. 118, 123 L.R.R.M. (BNA) 1137 (Sept. 30, 1986) (Myers II), review denied sub nom. Prill v. NLRB, 835 F.2d 1481 (D.C. Cir. 1987) (Prill II), cert. denied, 108 S. Ct. 2847 (1988). The facts and reasoning of the Board's decisions in Meyers are discussed at infra notes $176-83$ and accompanying text.

133. Herbert F. Darling, Inc., 267 N.L.R.B. 476 (1983), remanded sub nom. Ewing v. NLRB, 732 F.2d 1117 (2d Cir.), order reissued, 273 N.L.R.B. 346 (1984), rev'd and remanded sub nom. Ewing v. NLRB, 768 F.2d 51 (2d Cir. 1985) (Ewing II), order reissued, 287 N.L.R.B. No. 148, 127 L.R.R.M. (BNA) 1241 (Feb. 29, 1988) (Darling III), petition for review denied sub nom. Ewing v. NLRB, 861 F.2d 353 (2d Cir. 1988) (Eving III).

134. Webster's, for example, defines "concerted" as "mutually contrived or planned: agreed on ... [;] performed in unison: done together." Webster's Third New International Dictionary 470 (1986).

135. The Board's decision in Meyers $I$ came quite close to adopting this position: 'In general, to find an employee's activity to be 'concerted,' we shall require that it be engaged in with or on the authority of other employees, and not solely by and on behalf of the 
atop a "slippery slope" and has not been easy to maintain. For one thing, section 7 by its terms protects "the right to . . . form, join, or assist labor organizations . . . and to engage in other concerted activities," 136 strongly suggesting that such individual actions as "join[ing]" or "assist[ing]" a union are "concerted" and that the term thus means a great deal less than meets the eye. ${ }^{137}$ For another, even the staunchest advocates of the Meyers approach have been forced to agree that a lone employee who takes action with the object of promoting unionization or other collective action enjoys section 7 protection; ${ }^{138}$ indeed, in the former case, such an employee would seem to be exercising her express right to "form" a labor organization. So too the strategy's proponents have been constrained to concede that the provision covers the individual who protests alone but represents another in so doing. ${ }^{139}$

The second interpretive strategy conflates the "concert" language with the mutuality requirement. The development of this approach began as far back as the Board's 1966 decision in Interboro Contractors,

employee himself." 268 N.L.R.B. at 497 (emphasis added). In Mejers II, however, the Board backed off somewhat from this rigid formulation. See infra notes I38-39 \& 160 .

136. 29 U.S.C. $§ 157$ (1982) (emphasis added).

137. NLRB v. City Disposal Sys., Inc., 465 U.S. 822, 831 \& n.8 (1984). The word "other" did not appear in $\S 7$ of the Wagner Act, but was inserted by the Taft-Hartley amendments. See Comparison of the National Labor Relations Act of 1935 with Title I of the Labor Management Relations Act of 1947, 2 Legis. Hist. 1947, supra note 119, at 1666. The Hartley bill originally passed by the House read as follows (the italics indicate proposed additions to the language of the Wagner Act):

Employees shall have the right to self-organization, to form, join, or assist any labor organization, to bargain collectively through representatives of their own choosing, and to engage in other concerted activities (not constituting unfair labor practices under section $8(b)$, unlawful concerted activities under section 12 , or violations of collective-bargaining agreements) for the purpose of collective bargaining or other mutual aid or protection, and shall have the right to refrain from any or all such activities: Provided, that nothing herein shall preclude an employer from making and carrying out a [valid union-security] agreement . . . .

H.R. $3020 \& 7,80$ th Cong., Ist Sess. (1947), reprinted in 1 Legis. Hist. 1947, supra note 119 , at 176. Thus, the House bill contained an express exclusion from $\S 7$ protection for certain types of employee conduct (such as strikes in violation of a no-strike agreement) and an express provision protecting the "right to refrain" from concerted activity. See H. Rep. No. 245, 80th Cong., 1st Sess. 26-27 (1947), reprinted in I Legis. Hist. 1947, supra note 119, at 317-18. Presumably, the insertion of the word "other" prior to "concerted activities" was intended to make clear that employee efforts to "form, join, or assist any labor organization" were also "concerted activities" and accordingly subject both to the proposed exclusion and to the "right to refrain" provision. The exclusionary parenthetical was dropped in conference, but a modified version of the "right to refrain" language and the inserted "other" were retained in the final bill. See H. Conf. Rep. No. 510, 80th Cong., 1st Sess. 38-40 (1947), reprinted in 1 Legis. Hist. 1947, supra note 119 , at $542-44$; see also infra notes $278-84$ and accompanying text (discussing congressional rejection of the proposed exclusion).

138. Meyers II, 123 L.R.R.M. (BNA) at 1142; see also City Disposal, 465 U.S. at 846-47 (O'Connor, J., dissenting) (conceding concertedness in this context).

139. Meyers II, 123 L.R.R.M. (BNA) at 1141-42; see also City Disposal, 465 U.S. at 846 (O'Connor, J., dissenting) (conceding concertedness in this context). 
Inc. ${ }^{140}$ which found concert in an individual employee's attempt to vindicate a right guaranteed in his collective-bargaining agreement, and had its apotheosis in the agency's 1975 decision in Alleluia Cushion Co. ${ }^{141}$ On this view, the term concerted activities-like the expression mutual aid or protection-speaks "to the end, not the means." 142 As long as the lone employee's protest addresses "matters of great and continuing concern for all within the work force," her conduct is deemed "concerted." 143 Using this theory, the Board found the requisite concert in the following instances of individual employee conduct: sending a letter to an employer concerning the abusive conduct of a supervisor; ${ }^{144}$ filing a complaint with a state occupational safety and health agency; ${ }^{145}$ making an inquiry to an employer's bank to determine whether the employer had the funds to meet current payroll; ${ }^{146}$ and, applying the Interboro doctrine in City Disposal, refusing to drive a truck believed to be dangerous and thus invoking a contractual guarantee that the employer would not require employees to operate unsafe vehicles. ${ }^{147}$

The conflationist strategy of Alleluia Cushion is, of course, open to the objection that Congress should not be presumed to have legislated redundantly. ${ }^{148}$ Section 7 refers both to "concerted activities" and to "the purpose of . . mutual aid or protection," suggesting that the subject phrases do not mean the same thing. The objection is half right; to the enacting Congress, "concert" and "mutual aid or protection" had quite distinct purposes. But the Alleluia Cushion approach is nevertheless on to something. In their influential 1981 article on the subject, Professors Gorman and Finkin argued persuasively that the original purpose of the "concert" language was simply to insulate certain forms of protest activity-most notably, strikes, picketing, and the boycottagainst a hostile body of pre-Wagner Act judicial regulation. ${ }^{149}$

140. 157 N.L.R.B. 1295, 1298 (1966), enforced, 388 F.2d 495 (2d Cir. 1967).

141. 221 N.L.R.B. 999 (1975). The facts and reasoning of Alleluia Cushion are discussed at length at infra notes $165-75$ and accompanying text.

142. Randolph Div., Ethan Allen, Inc. v. NLRB, 513 F.2d 706, 708 (1st Cir. 1975).

143. Alleluia Cushion, 221 N.L.R.B. at 1000.

144. Hitchiner Mfg. Co., 238 N.L.R.B. 1253, 1257 (1979).

145. Alleluia Cushion, 221 N.L.R.B. at 1001.

146. Air Surrey Corp., 229 N.L.R.B. 1064, 1064 (1977), enforcement denied on other grounds, 601 F.2d 256 (6th Cir. 1979).

147. 256 N.L.R.B. 451,454 (1981), discussed supra notes $92-98$ and accompanying text. No doubt one or two of these cases might make even the most sympathetic reader uncomfortable. Keep in mind, however, that there is no question in each that the conduct at issue would be protected by $\S 7$ if it were engaged in by two or more employees. Thus, the only question here is whether the same protection extends to such conduct when it is undertaken on an individual basis.

148. See, e.g., Meyers I, 268 N.L.R.B. at 496; accord Meyers II, 123 L.R.R.M. (BNA) at $1139-41$.

149. Gorman \& Finkin, The Individual and the Requirement of "Concert" Under the National Labor Relations Act, 130 U. Pa. L. Rev. 286, 331-38 (1981). Staughton 
Although such activities were perfectly lawful (if utterly ineffectual) when undertaken by employees on an individual basis, the common-law doctrines of criminal conspiracy and restraint of trade, together with the prevailing interpretation of the federal antitrust laws, rendered them unlawful or actionable when undertaken collectively. ${ }^{150}$ The purpose of the "concerted activities" language in section 7, then, was to provide employees immunity from these judicial devices; by contrast, there is no evidence to suggest that the phrase was designed to impose a requirement that workers behave like a Greek chorus in order to enjoy protection against discipline or discharge at the hands of the employer. ${ }^{151}$ Thus, the intuition in Alleluia Cushion that the phrase might properly be ignored by collapsing it into the requirement of "mutual aid or protection" is defensible - at least outside of the context of its original immunizing function.

Significantly, the Gorman and Finkin study was cited with approval by the Supreme Court in City Disposal, which upheld the Board's Interboro doctrine. ${ }^{152}$ Relying on that study to find employee Brown's assertion of his contractual right to refuse to drive an unsafe truck "concerted," the Court concluded that "[t]here is no indication that Congress intended to limit [section 7] protection to situations in which an employee's activity and that of his fellow employees combine with one another in any particular way." 153 The Court did not go so far as to adopt the conflationist strategy of Alleluia Cushion and thus to read the requirement of concert out of section 7; indeed, it expressly declined to reach that question. ${ }^{154}$ Rather, the Court assumed that "concerted activities" and "mutual aid or protection" were distinct

Lynd had foreshadowed their work in Lynd, The Right to Engage in Concerted Activity After Union Recognition: A Study of Legislative History, 50 Ind. L.J. 720, 726-34 (1975). The legislative history of $\$ 7$-and the findings of Gorman and Finkin-are further considered at infra notes 216-76 and accompanying text.

150. See, e.g., Loewe v. Lawlor, 208 U.S. 274 (1908) (antitrust liability); Vegelahn v. Guntner, 167 Mass. 92, 44 N.E. 1077 (1896) (restraint of trade); The Pittsburgh Cordwainers Case [Commonwealth v. Morrow], Court of Quarter Sessions, Pittsburgh (1815), in $4 \mathrm{~J}$. Commons \& E. Gilmore, A Documentary History of American Industrial Society 15-87 (1910) (common law criminal conspiracy).

151. Gorman \& Finkin, supra note 149 , at 338 . To be sure, nor is there much evidence that the members of Congress actively contemplated protection for such individual activity. See George, Divided We Stand: Concerted Activity and the Maturing of the NLRA, 56 Geo. Wash. L. Rev. 509, 521-22 (1988). But see Finkin, Labor Law by Boz-A Theory of Meyers Industries, Inc., Sears, Roebuck and Co., and Bird Engineering, 71 lowa L. Rev. 155, 156-75 (1985) (finding an affirmative congressional purpose to protect individual recourse to public officials). That would not, however, preclude the Board from developing such protection-as it did in Alleluia Cushion and its progeny-as a matter of administrative discretion. See, e.g., NLRB v. Weingarten, Inc., 420 U.S. 251, 266-67 (1975) (upholding the Board's authority to adopt interpretation that is permitted but not required by the Act).

152. 465 U.S. at 835 .

153. Id.

154. See id. at 829 n.6 (distinguisbing Meyers $I$, which overruled Alleluia Cushion). 
requirements, but it moved the literalist strategy another step down the slippery slope by finding concert in the process of union organization, negotiation, and ratification "that gave rise to the [collective-bargaining] agreement" on which employee Brown had relied. ${ }^{155}$

As of this writing, however, the Board has announced its intention to adhere to the Meyers literalist strategy, at least outside the Interboro/City Disposal context. ${ }^{156}$ Moreover, the Courts of Appeals for the District of Columbia and Second Circuits have upheld this position as "consistent with," though not compelled by, the Act. ${ }^{157}$ Whether that decision will survive forthcoming changes in Board membershipor the force of gravity, as Meyers nears the bottom of the slippery slope-remains to be seen. ${ }^{158}$ What is of primary interest here are the

155. Id. at 831 .

156. Meyers II, 123 L.R.R.M. (BNA) at 1138-44. Significantly, when the Board overruled Alleluia Cushion "and its progeny" in Mejers $I$, it nevertheless left Interboro intact. The Board's reasoning was perfunctory at best: "The focal point in Interboro was, and must be, the attempted implementation of a collective-bargaining agreement. By contrast, in the Alleluia situation, there is no bargaining agreement, much less any attempt to enforce one, and we distinguish the two cases on that basis." 268 N.L.R.B. at 496. My sense is that the only reason the Board, then firmly in the control of Chair Dotson, bothered to distinguish Interboro-rather than simply to overrule it-was that a challenge to the doctrine was already pending before the Supreme Court in City Disposal. The City Disposal Court offered a more thoroughgoing basis for distinguishing Meyers and thus avoided reaching the Alleluia Cushion question in that case. See supra text accompanying note 155; see also Mejers II, 123 L.R.R.M. (BNA) at 1142-44 (adopting Supreme Court's rationale).

157. Prill II, 835 F.2d at 1484 (sustaining Meyers II); Ewing III, 861 F.2d at 359 (sustaining but criticizing Meyers II). In Meyers I, the Board, once again attempting to enshrine its wisdom for the ages, had concluded that the literalist approach was "mandated" by the Act, 268 N.L.R.B. at 496, a conclusion that was rejected by the D.C. Circuit on review, Prill I, 755 F.2d at 950-53, as well as by the Second Circuit, the only other court to address the question, Ezwing II, $768 \mathrm{~F} .2 \mathrm{~d}$ at $54-55$. It is somewhat ironic that these two circuits were the ones to reject the Board's position that Meyers literalism was other than a policy choice; each court had itself previously criticized the conflationist interpretive strategy on essentially plain meaning grounds. See Ontario Knife Co. v. NLRB, 637 F.2d 840, 845 (2d Cir. 1980) (rejecting Alleluia Cushion's reasoning); Kohls v. NLRB, 629 F.2d 173, 176-77 (D.C. Cir. 1980) (dictum questioning Interboro doctrine), cert. denied, 450 U.S. 931 (1981). Indeed, it was partly those very criticisms-and those by a number of other reviewing courts-that prompted the Board in Meyers $I$ to overrule Alleluia Cushion and adopt a literal interpretation of concert. See 268 N.L.R.B. at 496 \& n.18, $497 \&$ n.22 (citing cases).

158. In addition to the forces exerted by the concessions made for the Interboro doctrine and the other situations described above, see supra notes 136-39 and accompanying text, three other argnmentative strategies leave Meyers perilously poised. First, City Disposal itself suggested cryptically that "an employer [could] commit an unfair labor practice by discharging an employee who is not himself involved in concerted activity, but whose actions are related to other employees' concerted activities in such a manner as to render his discharge an interference or restraint on those activities" within the meaning of $\S 8(a)(1)$ of the Act, 29 U.S.C. $\S 158(a)(1)$ (1982). 465 U.S. at 833 n. 10. This "chilling effect" rationale was noted by the court in Ewing $I I, 768$ F.2d at 55-56, which rejected Meyers $I$ and held that $\$ 7$ could permissibly be read to protect individual protest activity where discipline of the protester might deter coworkers from engaging 
assumptions that seem to underlie the debate between the adherents of Meyers and Alleluia Cushion, respectively.

in similar behavior. The Board has thus far resisted this argument at the rhetorical level, but it has succumbed on an ad hoc basis in a number of cases. Compare Darling III, 127 L.R.R.M. (BNA) at 1245 (suggesting that agency would not find forbidden "chill" in the absence of evidence of protest activities by other employees) and Meyers II, 123 L.R.R.M. (BNA) at 1144 (same) with Unico Replacement Parts, Inc., 281 N.L.R.B. No. 46, 123 L.R.R.M. (BNA) 1106, 1106 (Sept. 8, 1986) (employer violated Act by threatening to close plant in response to individual employee's complaint to OSHA, because other employees were present) and Certified Serv., Inc., 270 N.L.R.B. 360, 360 (1984) (employer violated Act in similar circumstances). For a thoughtful argument along these lines, see George, supra note 151 , at 523-39.

A second argumentative strategy renders Meyers vulnerable to slippage in the context of an individual employee's attempts to invoke a right grounded in worker-protective legislation by "whistleblowing" or refusing to engage in unlawful conduct. See, e.g., Alleluia Cushion, 221 N.L.R.B. at 999 (filing of complaint with a state occupational health and safety agency); Meyers I, 268 N.L.R.B. at 497 (refusing to drive truck that state highway safety agency "put out of service"). The idea here is to analogize the "concert" present in the negotiation and ratification of a collective-bargaining agreement to the efforts of representatives of working people to press for enactment of protective legislation. If the "process that gave rise to the [collective-bargaining] agreement" in City Disposal made employee Brown's later attempt to vindicate a provision in the contract "concerted," see supra text accompanying note 155, the argument goes, so too should the requisite concert be found in the process that gave rise to the legislation invoked by an individual protester. See Prill I, 755 F.2d at 953 n.72; see also Meyers I, 268 N.L.R.B. at 499-503 (Zimmerman, dissenting) (defending Alleluia Cushion on similar grounds). In Meyers $I I$, the Board rejected this analogy, explaining that the "lobbying process preceding the passage of such legislation" is "far removed from the particular workplace," 123 L.R.R.M. (BNA) at 1I42-44-a point the significance of which is difficult to discern, given the statutory definition of "employees" who enjoy $\S 7$ rights, see N.L.R.A. § 2(3), 29 U.S.C. $§ 152(3)$ ("The term 'employee' shall include any employee, and shall not be limited to the employees of a particular employer, unless [the Act] explicitly states otherwise.") (emphasis added); see also Eastex, Inc., v. NLRB, 437 U.S. 556, 566 (1978) (relying on $\$ 2(3)$ to hold that "appeals to legislators to protect their interests as employees" are within the scope of $\S 7$ ).

Quite apart from recourse to such expansive notions of concert, the cases that protect whistleblowers or employees who refuse to break the law might also be defended on traditional "public policy" grounds. This approach might best be illustrated by comparing two hypothetical cases of "the killer truckdriver." In the first, a driver is discharged by his employer for engaging in what is admittedly $\$ 7$ activity. During the typical threeto-four-year delay between the firing and review of the case by the administrative law judge, the Board, and the courts, the dischargee accumulates a breathtaking number of serious speeding violations. Naturally, the employer raises these violations in an effort to defeat a reinstatement order. In the typical case, the employer prevails, and the reader is treated to a lecture on the "incompatibility" of reinstatement "with the safety on the public highways" and the need to construe the Labor Act to accommodate such concerns. See, e.g., NLRB v. Big Three Indus. Gas \& Equip. Co., 405 F.2d 1140, 1143 (5th Cir. 1969). Contrast this situation with the employer who discharges an employee for refusing to become a "killer truckdriver"-for refusing to drive a dangerous vehicle (as was the case in Meyers) or resisting an order to exceed the speed limit by a considerable measure (to track the first hypothetical). The result-in Meyers, at least-is a rejection of the argument that the Board should construe the Act to serve the ends of public safety (by declaring the employee's conduct "concerted" and therefore protected), cou- 
b. Alleluia Cushion and Meyers. - As the skeptical reader has no doubt observed, the two competing strategies would virtually merge if the Meyers approach were pushed just a little further down its slippery slope. Thus, the literalists' concession that the individual who represents another meets the concert requirement creates a loophole large enough not to drive a truck through. ${ }^{159}$ After all, the situation in which an individual employee acts on the express authority of a colleague is indistinguishable in principle from one in which representation is implied by her colleague's conduct-a fact that the Meyers Board has now somewhat grudgingly acknowledged. ${ }^{160}$ Yet it is only a slightly larger leap from there to the situation in which representation might be rea-

pled with a sarcastic reminder that the Board "is neither God nor the Department of Transportation." Meyers I, 268 N.L.R.B. at 499.

Why, it is fair to ask, do the agency and the reviewing courts feel free to play God and the DOT in the first of the cases (where the employer seeks to use "public policy" to trump $\$ 7$ rights), but not in the second (where the employee seeks to use the notion to expand such rights)? The answer may lie in some deeper commitment to the separation of the "public" from the "private" in labor law, a phenomenon insightfully described and explored in the work of Karl Klare and Ken Casebeer, among others. See Klare, supra note 4; Casebeer, supra note 2. Thus, in this context as in so many others in the labor area, the "private" common-law regime of contract, property, and tort is elevated to the status of the "rule" (for example, the at-will employment rule); by contrast, the "public" law commands of the Labor Act are confined to a series of narrowly drawn "exceptions" to that private regime (for example, you can not fire an otherwise exemplary employee for union organizing). And, while enforcement of the public-law norms (like Board reinstatement orders) can legitimately be tailored to accommodate competing claims of "public" policy, the private-law regime is permitted to operate in a manner relatively immune from such encroachments. Indeed, it is a tribute to the remarkable persistence of this public-private distinction in the public-law context that participants in its discourse continue to view the two hypotheticals as fundamentally "different," long after the private-law regime has for the most part adopted for whistleblowers and the like a "public policy" exception to the at-will rule. See supra note 2 . See generally J. Atleson, supra note 4 (describing ways in which out-dated private-law assumptions govern application of the Act).

159. The prevalence of truck driver cases in the concert context is no coincidence. Given the nature of their work and the way job assignments are generally made in the industry, a concerted refusal to drive a single vehicle is a possible but unlikely event. Thus, for example, employee Brown in City Disposal was alone when he was ordered to drive, 465 U.S. at 826-27, and the driver in Meyers was out on the road and received his instructions over the phone, 268 N.L.R.B. at 497; see also ABF Freight Sys., 271 N.L.R.B. 35, 35 (1984) (frustrated attempt by an individual employee to secure the "concert" of others in his refusal to drive a truck).

160. In Mannington Mills, Inc., 272 N.L.R.B. 176 (1984), the Board had adhered to the narrow definition of concert set forth in Meyers $I$ and held in effect that a would-be representer must act upon express authority of her colleagnes. See Prill 1,755 F.2d at 948-49 \& n.48, 954 \& nn.77-78 (criticizing Mannington Mills as inconsistent with earlier Board and court decisions). In $M$ eyers $I I$, however, the agency conceded that a finding of concert was appropriate when "an individual, not a designated spokesman, brought a group complaint to the attention of management." 123 L.R.R.M. (BNA) at 1141 \& nn.34-35 (emphasis added). Indeed, it suggested that it would examine "the totality of the record evidence" to determine whether representation-concert was present, "whether 'specifically authorized' in a formal agency sense, or otherwise." Id. at 1141. 
sonably implied from the nature of the object of the protest; surely a claim that addresses "matters of great and continuing concern for all within the work force"'161 is likely to be supported by other employees. ${ }^{162}$ This, of course, was the rationale of Alleluia Cushion; ${ }^{163}$ it was also the central focus of the Board's rejection of Alleluia in Meyers $I$ and of the many judicial critiques of Alleluia that predated Meyers $I^{164}$ That this is the principal point of conflict is revealing indeed. Once again, an examination of the rhetoric of justification suggests the central importance of the assumption that one's working colleagues would support one's protest only if moved to do so by self-interest and the resulting marginalization of the interests of the one whose claims are at stake.

In Alleluia Cushion, the employer, a manufacturer of carpet cushions, had discharged maintenance employee Jack Henley, allegedly for filing a complaint with a state occupational safety and health agency. ${ }^{165}$ Henley had listed a number of concerns, among them several that affected him directly (for example, the absence of any first-aid stations at the plant), but most of which did not (for example, the lack of instruction regarding various chemicals used in the employer's production process). ${ }^{166}$ The Board held that Henley's complaint to the state agency was "concerted" within the meaning of section 7 because workplace safety, the object of his protest, was of "great and continuing concern" to employees generally. ${ }^{167}$ Noting that Henley had attempted to invoke rights guaranteed by state law, the Board rejected the argument that it should "presume that, absent an outward manifestation of support, Henley's fellow employees did not agree with his efforts to secure compliance with the statutory obligations imposed on Respondent for their benefit."168 Accordingly, the Board concluded: "[W]here an employee speaks up and seeks to enforce statutory provisions relating to occupational safety designed for the benefit of all employees, in the absence of any evidence that fellow employees disavow such representation, we will find an implied consent thereto and deem such activity to be concerted."169 The Board found that the case for finding "implied con-

161. Alleluia Cushion, 221 N.L.R.B. at 1000.

162. See, e.g., Ewing $I I, 768$ F.2d at 55 ("Group support may rationally be assumed, absent evidence to the contrary, because fellow employees presumably want to be free to assert such a right [for example, to inform public authorities of dangerous working conditions] without fear of losing their jobs.").

163. See supra notes $141-43$ and accompanying text.

164. See Meyers I, 268 N.L.R.B. at 495-96; see also id. at 496 \& n.18, $497 \&$ n.22 (collecting court cases that had rejected Alleluia Cushion).

165. 221 N.L.R.B. at 999 n.6.

166. Id. at $999 \& \mathrm{n} .3,1001$.

167. Id. at 1000.

168. Id.

169. Id. (emphasis added). The Board's opinion also suggested an alternative rationale for finding "concert" in this context, in the "consent and concert of action [that] emanates from the mere assertion of such statutory rights." Id. (emphasis added). This statutory aspect of the case may well have played a large part in prompting the Board to 
sent" among his coworkers was particularly strong in Henley's case, reasoning as follows:

While his own personal safety may have been one motivation, it is clear from the nature and extent of the safety complaints registered that Henley's object encompassed the well-being of his fellow employees. Most of the conditions he sought to remedy, i.e., live electrical wires in work areas, lack of instruction regarding chemicals used in production, and inadequate ventilation, involved work areas and potential hazards that Henley was unlikely to encounter. In fact, the one specific safety improvement the protests accomplished-the installation of eyewash stands-directly benefits the employees [elsewhere at the plant] and only marginally affects Henley. ${ }^{170}$

No doubt by now this analytical structure looks quite familiar: It is Peter Cailler's gloss on "mutuality." To be more precise, it is reversePeter Cailler, the interpretive strategy evident in cases like Weingarten and City Disposal, in which an employee seeks the aid of others to further her own cause. ${ }^{171}$ Since Allehia Cushion in effect conflates the mutuality and concert requirements-treating both as primarily an inquiry into "end[s], not the means"172- the use of the mutuality strategy in the concert context should come as no surprise. But note the particular way in which that strategy is put to work here: Support by Henley's colleagues for his cause is presumed because of the "benefit" not to him, but to them. Indeed, the Board goes out of its way to portray Henley's actions as only "marginally" self-interested; it is clear that his protest is worthy of protection only because its object "encompassed the well-being of his fellow employees." 173

To be sure, the use of the "interests of the others" framework is more justifiable here than it was in the mutuality context. The Board must, after all, engage in hypothesis contrary to fact and determine without direct evidence whether Henley's colleagues would have supported him had they been called to his aid. ${ }^{174}$ And the assumption that they would have been likely to have done so given their own substantial interest in the objects of his protest is, to say the least, reasonable-

reach the conclusion it did in Alleluia Cushion. Significantly, however, the agency proceeded after this case to find concert in a series of contexts that did not involve such legislation, relying in such cases solely upon the "matters-of-great-and-continuing-concern" rationale. See, e.g., Hitchiner Mfg. Co., 238 N.L.R.B. 1253, 1257 (1979); Air Surrey Corp., 229 N.L.R.B. 1064, 1064 (1977), enforcement denied, 601 F.2d 256 (6th Cir. 1979). The alternative strategy of finding concert in the enactment of worker-protective legislation is discussed more fully at supra note 158 .

170. Alleluia Cushion, 221 N.L.R.B. at 1000-01.

171. See supra notes 86-98 and accompanying text.

172. Randolph Div., Ethan Allen, lnc. v. NLRB, 513 F.2d 706, 708 (1st Cir. 1975).

173. Alleluia Cusion, 221 N.L.R.B. at 1001 (emphasis added).

174. That is, unless the agency were to decide to depart from its broader policy of eschewing inquiry into the subjective state-of-mind of employees and summon Henley's colleagues to the witness stand. See supra note 29. 
particularly "in the absence of any evidence that fellow employees disavow such representation." 175 But the Board takes the analysis a step further when it goes to such lengths to stress the "marginal[]" nature of Henley's personal interest in the objects of his protest. This suggests that his colleagues-and thus the Board and the courts-would turn their backs on him were the thrust of his protest an effort to vindicate his own claim.

The assumption of collegial indifference to the individual's plight-and the corresponding resistance to the latter's self-interested claims-came home to roost in Meyers. In that case, the employer had discharged employee Kenneth Prill for refusing to drive a truck whose malfunctioning brakes had caused him to have an accident and for bringing the vehicle's condition to the attention of state public authorities. 176 The administrative law judge, relying on Alleluia Cushion, found that Prill's actions constituted "concerted activity" and that the discharge thus violated the Act. ${ }^{177}$

The Board reversed. Scarcely containing its institutional exhilaration at the prospect of "overrul[ing] Alleluia and its progeny,"178 the Board declared that henceforth, "to find an employee's activity to be 'concerted,' we shall require that it be engaged in with or on the authority of other employees, and not solely by and on behalf of the employee himself." 179 The thrust of the Board's reasoning-and the reasoning in its subsequent reaffirmation of this standard in Meyers IIwas its assertion that the language of section 7 supports separate requirements of concert of action and mutuality of purpose. ${ }^{180}$ But what seemed to bother the Board most about Alleluia Cushion was the notion that the agency could ever reasonably presume collegial concern for a coworker's claim in the absence of extrinsic proof of such support:

Instead of looking at the observable evidence of group action to see what men and women in the workplace in fact chose as an issue about which to take some action, it was the Board that determined the existence of an issue about which employees

175. Alleluia Cushion, 221 N.L.R.B. at 1000. Contrast this with Hendricks, where recourse to this framework led the Board to posit self-interested reasons for support that appeared to be motivated by love and solidarity. See supra notes 10-16 and accompanying text.

176. Meyers $I, 268$ N.L.R.B. at $497-98$.

177. 1d. at 498 .

178. Id. at 496.

179. Id. at 497. As earlier notes suggest, the Board relaxed this rigid formulation somewhat in Meyers II. See 123 L.R.R.M. (BNA) at 1141-42; see also supra notes $138-39$ \& 160 and accompanying text.

180. Mejers I, 268 N.L.R.B. at 496; see Meyers II, 123 L.R.R.M. (BNA) at 1139-41. In Meyers $I$, the Board held that this reading of $\S 7$ was "mandated" by the Act, 268 N.L.R.B. at 496; after the judicial rejections of that position in Prill $I$ and Ewing $I I$, the Board retrenched and held that it was adopting that interpretation as a matter of administrative discretion. Meyers II, 123 L.R.R.M. (BNA) at 1138, I143; see supra note 157. 
ought to have a group concern. ${ }^{181}$

Turning to the application of its new standard to the facts of the case, the Board stressed that Prill acted "alone" and "solely on his own behalf."182 The Board therefore reasoned that, "without the artificial presumption Alleluia created, the facts of this case do not support a finding that Prill engaged in concerted activity." 183

Thus, Meyers adopts an analytical structure that is similar to the one evident in Alleluia Cushion, albeit with dramatically different results. Characterizing as "artificial" the notion that Prill's fellow drivers could be presumed to support action taken by him "solely on his own behalf" and "for himself alone," the Board ignored the possibility that the other employees might have identified with his plight or even shared a genuine concern for the well-being of Prill himself. Without "observable evidence" of their support, their interest in the matter would simply not be presumed, and, accordingly, section 7 protection for Prill's protest was deemed to be unwarranted.

\section{B. Self/Others Outside of Section 7: \\ Collective Bargaining on Behalf of Retirees}

The phenomena under examination are apparent outside of section 7 as well. Take, for example, the Supreme Court's decision in Allied Chemical E' Alkali Workers v. Pittsburgh Plate Glass Co., ${ }^{184}$ which held that an employer need not bargain collectively with respect to the pension and health insurance benefits of its retired workers. Although the doctrinal details are different, ${ }^{185}$ once again the structure of the analysis employed simultaneously denies the legitimacy of the claims of employees who would seek the support of their fellow workers and of the efforts of those who would come to their aid.

Beginning in 1950 and for over fifteen years thereafter, the union in Allied Chemical negotiated collective-bargaining agreements with the employer that governed the health insurance benefits of retirees. The early agreements were somewhat tentative-they were not reduced to writing and merely permitted the retired workers to participate in the current employees' plan, deducting the total cost of their premiums from their pension payments. Over the years, however, various improvements were instituted by the parties (including the implementation of a direct contribution by the employer) and were eventually included in the formal provisions of the union contract. ${ }^{186}$ In the wake

181. Meyers I, 268 N.L.R.B. at 495.

182. Id. at 498 .

183. Id.

184. 404 U.S. 157 (1971).

185. See infra note 188 .

186. 404 U.S. at 160-61; see also the underlying Board decision, Pittsburgh Plate Glass Co., Chem. Div., 177 N.L.R.B. 911,911 (1969), enforcement denied, 427 F.2d 936 (6th Cir. 1970), aff'd, 404 U.S. 157 (1971). 
of the congressional enactment of Medicare in 1965, however, the employer announced its intention to cancel the negotiated plan, which it considered duplicative of the benefits available under the new legislation. It proposed to substitute an employer-paid contribution toward supplemental Medicare coverage for the retired employees. The union objected to the employer's unilateral change of the negotiated plan, and the employer reconsidered, announcing that instead it would offer individual retirees the option of continuing coverage under the negotiated plan or of withdrawing from the plan in exchange for an employer contribution toward the retirees' supplemental Medicare premiums. The union again objected to the employer's actions and requested collective-bargaining over the matter, but the employer refused. ${ }^{187}$

The union filed an unfair labor practice charge with the Board, alleging that the retirees' health insurance benefits constituted a "mandatory subject of bargaining" and, accordingly, that the employer's mid-term modification of the plan violated the duty to bargain imposed by the Act. ${ }^{188}$ The employer defended, contending, among other things, that the retired workers were not members of the current employees' bargaining unit and, accordingly, that the obligation to bargain with the union did not extend to matters that affected only the retirees. ${ }^{189}$

The Board rejected the employer's claim and found that the refusal

187. 404 U.S. at 161-62; 177 N.L.R.B. at 911-12. The union's resistance to the employer's change evidently enjoyed the overwhelming support of the firm's 190 retired workers; ultimately, only 15 of them accepted the option of withdrawing from the negotiated plan in favor of the employer-paid Medicare contribution. 404 U.S. at 162.

188. Sections 8(a)(5), 8(d), and 9(a) of the Act, 29 U.S.C. $\$ \S 158(a)(5),(d), 159$ (a) (1982), obligate an employer to bargain collectively with a union selected by a majority of employees in a Board-certified bargaining unit. This obligation extends both to the initial negotiation of collective-bargaining agreements and to any subsequent modifications thereof. See, e.g., NLRB v. Katz, 369 U.S. 736, $742-43$ (1962). Section 8(d), however, limits the employer's bargaining obligation to "wages, hours, and other terms and conditions of employment"- the so-called "mandatory subject[s] of bargaining," see, e.g., Allied Chemical, 404 U.S. at 176-83, which are to be distinguished from merely "permissive" subjects, with respect to which the parties are free, though not legally bound, to bargain, see NLRB v. Wooster Div. of Borg-Warner Corp., 356 U.S. 342, 349 (1958). See generally Note, Subjects of Bargaining Under the NLRA and the Limits of Liberal Political Imagination, 97 Harv. L. Rev. 475 (1983) (exploring the ideological role of the distinction between permissive and mandatory bargaining subjects).

By the time of Allied Chemical, decisional law had long held that the pension and insurance benefits of current employees constituted a mandatory subject of bargaining. See 404 U.S. at $159 \&$ n.l (citing cases). Thus, the precise question raised by the union's charge was whether the same principle applied to the benefits of retired workers.

189. The employer also argued that retirees were not "employees" within the meaning of $\S 2(3)$ of the Labor Act, 29 U.S.C. $\$ 152(3)$. The Supreme Court ultimately agreed, reasoning that "[t]he ordinary meaning of "employee" " is one who "work[s] for another for hire," and that "an individual who has ceased work without expectation of further employment" does not fit that description. 404 U.S. at 168. On the assumptions revealed by this argument and related arguments supporting a multitude of employee exclusions from the Act, see R.M. Fischl, Which Side Are You On? The Hierarchical 
to bargain violated the Act. First, the Board noted that the retirees "ha[d] deep legal, economic, and emotional attachments to a bargaining unit."190 The Board continued:

When an employee retires from the bargaining unit, most of the threads which once bound him to the unit are severed, except those which affect his retirement rights. But his retirement status is a substantial connection to the bargaining unit, for it is the culmination and the product of years of employment. ${ }^{191}$

The retirees were thus de facto unit members, the Board held, at least with respect to their pension and health care benefits. Accordingly, the employer was obligated to bargain with the union over this "term and condition" of the retirees' employment, just as it was obligated to bargain over the health insurance benefits of current employees. ${ }^{192}$

The Board further concluded that the retirees' health insurance benefits constituted a "term and condition" of employment for the current employees and thus a mandatory bargaining subject with respect to them, even if the retirees themselves were held to be outside the bargaining unit. The Board asserted that the current employees had "a selfish as well as a compassionate interest in bargaining about the adequacy and the administration of benefits for retired employees."193 In the first place, the Board argued, the participation of the retirees in the health insurance plan could directly benefit the current employees, since such participation "enlarges [the plan's] size and might thereby lower costs per participant." 194 Moreover, the Board contended, by negotiating with respect to retirement benefits, the current employees were ensuring that "their own health needs w[ould] be adequately met upon their future retirement."195 The Board elaborated this argument before the Supreme Court:

[N] either the bargaining representative nor the active employees . . can help but recognize that the active employees of today are the retirees of tomorrow-indeed, such a realization undoubtedly underlies the widespread industrial practice of bargaining about benefits of those who have already retired ... and explains the vigorous interest which the Union has taken in this case. ${ }^{196}$

The Supreme Court reversed. Rejecting the Board's contention

and Boundary Exclusions of Employees from the National Labor Relations Act (1988) (unpublished manuscript) (on file at the Columbia Law Review).

190. 177 N.L.R.B. at 914.

191. Id.

192. See supra note 188 .

193. 177 N.L.R.B. at 915.

194. Id.

195. Id. (emphasis added).

196. Allied Chem. \& Alkali Workers Local 1 v. Pittsburgh Plate Glass Co., 404 U.S. 157,182 (1971). 
that retirees were effectively members of the current employees' bargaining unit, the Court relied on the longstanding Board practice of limiting bargaining-unit membership to individuals who share a "community of interest" "with other unit members. ${ }^{197}$ That practice, the Court observed, is designed to facilitate two related policies: It "assure[s] the coherence [of interests] among employees necessary for efficient collective bargaining"; and it "prevent[s] a functionally distinct minority group of employees from being submerged in an overly large unit."198

The Court concluded that inclusion of the retirees in the current employees' unit would frustrate both policies. First, the Court reasoned that the unique interests of the retirees would have a negative impact on the collective bargaining process:

Pensioners' interests extend only to retirement benefits, to the exclusion of wage rates, hours, working conditions, and all other terms of active employment. Incorporation of such a limited purpose constituency in the bargaining unit would create the potential for severe internal conflicts that would impair the unit's ability to function and would disrupt the processes of collective bargaining. ${ }^{199}$

At the same time, the Court argued that the interests of the retired workers might be "submerged" in favor of those of the current employees, noting that the "risk cannot be overlooked that union representatives on occasion might see fit to bargain for improved wages or other conditions favoring active employees at the expense of retirees' benefits."200

The Court rejected as well the Board's alternative rationale-that the health insurance benefits of the retirees workers constituted a "term[] and condition[] of employment" for the current workers. ${ }^{201}$ First, the Court dismissed the contention that the participation of the retirees in the health insurance plan would benefit the current employees by "lower[ing] the rate" per participant, asserting that "including pensioners, who are likely to have higher medical expenses, may more than offset" any such beneficial effect. ${ }^{202}$ Nor did the Court agree that bargaining on behalf of the retirees served the current employees' interest in assuring, as the Board had argued, that "their own health needs will be adequately met upon their future retirement."203 The

197. Id. at 174. See generally R. Gorman, supra note 41 , ch. 5, § 2 ("Criteria for Unit Determinations").

198. 404 U.S. at 172-73; accord NLRB v. Action Automotive, Inc., 469 U.S. 490, 494 (1985) (invoking same analysis to exclude from rank-and-file bargaining unit relatives of owner-managers of closely held corporation).

199. 404 U.S. at 173.

200. Id. (footnote omitted).

201. Id. at 180 .

202. Id.

203. 177 N.L.R.B. at 915. 
Court pointed out that employees "are not forever thereafter bound to that view or obliged to negotiate in behalf of retirees" and thus might at some point "decide, for example, that current income is preferable to greater certainty in their own retirement benefits or, indeed, to their retirement benefits altogether. By advancing pensioners' interests now, active employees, therefore, have no assurance that they will be the beneficiaries of similar representation when they retire."204 Similarly, the Court made short shrift of the Board's argument that the " "widespread industrial practice of bargaining about [retiree] benefits' " and the " "vigorous interest which the Union [took] in this case" " were attributable to any self-interest of current employees in the issue, observing tersely that "we find nowhere a particle of evidence cited showing that the explanation for this lies in the concern of active workers for their own future retirement benefits."205 Accordingly, the Court held that the employer was not required to bargain with the union before unilaterally altering the benefits of retired employees. ${ }^{206}$

In sum, then, both the Board and the Court assumed that the employer's duty to bargain over the retirees' health insurance benefits could be justified, if at all, only if either one of two conditions were met. On the one hand, the duty to bargain could be justified on the basis of the self-interest of the retirees if the retirees could be considered members of the bargaining unit. On the other, the duty to bargain could be justified if the current employees had a direct self-interest in the existing retirement-benefits issue. But neither tribunal considered the possibility that the bargaining obligation might be extended on the basis of the current employees' sense of loyalty to or solidarity with the retirees. ${ }^{207}$ And, although the Board would nevertheless have imposed a duty to bargain, the acceptance of this analytical structure proved to be fatal in the hands of the Supreme Court.

Molded by that structure, the Court's opinion reveals an image of the human relationships at stake that is as depressing as it is disconnected to social reality. To the Court, the retired workers were merely a "limited-purpose constituency," with no concern for the current employees' "wage rates, hours, working conditions, and all other terms of active employment." 208 Were they included in the bargaining unit, their insistence on their own selfish interest in retirement-benefit issues

204. 404 U.S. at 181.

205. Id. at 182 (emphasis added).

206. The Court's holding did not leave the union in the subject case without a remedy, for it was free to sue for breach of the provisions of the existing contract. Id. at 188.

207. Indeed, the Board explicitly assumed that a "selfish" interest of the current employees" was necessary and that their "compassionate interest" in the retirees was not enough, 177 N.L.R.B. at 915 . The Court simply rejected the Board's factual premise that any such "selfish" interest was present and, accordingly, held that there was no duty to bargain. See supra text accompanying note 205 .

208. 404 U.S. at 173. 
would threaten "severe internal conflicts" in the unit and "disrupt the processes of collective bargaining." 209 The Court was similarly generous with respect to the assumptions it made about the motives and behavior of the current employees. They could not be trusted to represent responsibly the interests of the retired workers, for the "risk c[ould] not be overlooked" that they would, in effect, sell out the retirees in order to obtain "improved wages or other conditions" for themselves. ${ }^{210}$ And the current employees could count on becoming the beneficiaries of similarly untrustworthy representation when they retire, since the employees of the future could, in turn, sell them out, deciding "that current income is preferable to greater certainty in their own retirement benefits or, indeed, to their retirement benefits altogether."211

The Court's assumptions are difficult to square with the facts that the current employees' union had been bargaining for retiree benefits for a decade and a half at the time the dispute arose, had done so without any evidence of disruption to unit cohesiveness, had consistently pressed for-and, up to the very end, obtained-substantial improvements in the benefits, and had fought for the right to continue to do so all the way to the United States Supreme Court. ${ }^{212}$ The Court's images are even more striking, when viewed in the light of the real-world relationship between the retired and current employees-a relationship never acknowledged in the Court's opinion. ${ }^{213}$ The retirees at Pitts-

209. Id.

2I0. Id. at I72-73. The Court's reliance on this concern is somewhat ironic, not to say disingenuous, given the result in the case. The Court did not, after all, rule that management and the union could not bargain over the issue of retirees' pension rights; it held only that management was not obligated to do so-that is, that the issue was a "permissive," not a "mandatory," bargaining subject. See supra note 188. Indeed, the Court went out of its way to observe that "nothing in [its] opinion preclude[d]" the union from representing the retirees with respect to the issue, provided that "the employer agrees." 404 U.S. at $181 \mathrm{n} .20$. Perhaps the Court was of the view that, although the current employees could not be trusted to bargain responsibly over the retirees' benefits, management could. Indeed, management could even be trusted not to bargain, and simply to determine unilaterally -as it did in this case-what was best for the retirees.

In any event, as the Court conceded, to the extent that the retirees' rights under the existing contract had vested, they could not be bargained away by either the union or management without the retirees' consent. Id. Accordingly, even if the union ceased actively to seek to better the lot of the retirees, it is not clear how much mandatory bargaining could have hurt them either. See 177 N.L.R.B. at 917 (Board decision). But see 404 U.S. at 173 \& n.12 (questioning Board's premise that "collective bargaining over the benefits of already retired employees would be a one-way street in their favor").

211. 404 U.S. at 181.

212. Apparently, these circumstances were not unique; the Board found-and the Court did not dispute-a contemporaneous "widespread industrial practice" of collective bargaining over the benefits of retired employees. 1d. at 182; see 177 N.L.R.B. at 916-17 (Board decision).

213. The Board fares better in this respect. See supra text accompanying notes $190-91$. 
burgh Plate Glass were not, after all, strangers to the current workers. They had worked shoulder-to-shoulder with them for years, attended union meetings together, and, no doubt, company picnics as well. They were their parents, their elders, their neighbors, their friends. But the Court's imagery of the employment relation obscured such considerations and led to a rejection of the solidarity-inspired actions of the current employees and to a marginalization of the retirees' stakes.

\section{The Road Not Taken}

The prevalence of the search for self-interest in the jurisprudence governing the purpose and manner of workplace protests provokes the question whether the development of this interpretive phenomenon can be traced to the language or history of section 7 itself. The provision does, after all, speak of protest activities undertaken "for the purpose of mutual aid or protection." On one reading, this language might be understood to require direct and genuine reciprocity, so that protesters and their beneficiaries must be "aid[ing]" or "protect[ing]" each other (if not necessarily at the same moment in time) in order to gain section 7 protection. ${ }^{214}$ And since the beneficiaries are by definition "aided" by the protests in the cases we are discussing, it is only the interests of those whose "aid" or "protection" is given or sought that is ever in question; hence the search for their self-interest. But an equally plausible interpretation of the language in question is that employees are simply empowered to "aid" and "protect[]" one another, whether or not there is any realistic prospect, expectation, or hope of ever gaining a reciprocal benefit. This, as we have seen, is consistent with much (though by no means all) of what the Board and the courts actually $d o$. Indeed, the origin of the "mutual aid or protection" language suggests that this latter interpretation is more consonant than the first with the contemporaneous understanding of the provision.

The genesis of the "mutual aid or protection" language may well have been the working class experience of solidarity or "mutualism," itself a rejection of the individualism immanent in a regime of reciprocal self-interest. ${ }^{215}$ Additionally, a closer examination of Judge Learned Hand's opinion in Peter Cailler, the source of the "promise of reciprocal benefit" interpretive strategy, suggests that the case has been widely misunderstood; like other contemporaneous constructions of section 7, Hand's reasoning seems to have assumed that the provision protected solidarity and mutualism, not simply self-interest.

214. See supra note 5 and accompanying text.

215. Indeed, the word "mutual" itself has a longstanding alternative usage that re jects the connotation of reciprocity and signifies instead the notion of a "shared" or "common" object. See Safire, supra note 5, at 20 (criticizing but acknowledging alternative usage). 


\section{A. Once More Into the Breach: The Legislative History of Section 7}

1. A Common Law for Labor Relations. - The story of the displacement of the nineteenth century common-law regulation of labor with the Norris-LaGuardia and Wagner Acts in the 1930s-after a false start with the Clayton Act two decades before-is by now a familiar one. I shall briefly recount it here to emphasize a piece of it with special relevance to the themes of this Article: A principal target of the federal legislation that emerged was a body of doctrine that evaluated the legality of strikes, picketing, and the like on the basis of the relative selfinterest of the protesters in the object of their protest.

The story begins with a body of late nineteenth century jurisprudence, briefly described in the section on concert, that was available to employers faced with the deployment of labor's principal economic weapons in its struggles with capital: strikes, picketing, and the boycott. $^{216}$ Labor's weapons were designed to pressure capital into making the concessions sought and, obviously, had to hurt to work. Contemporary tort doctrine made the resulting injury actionable-indeed, enjoinable - unless privileged, ${ }^{217}$ and injury in this context was held to be privileged only to the extent that the challenged conduct had as its purpose or object the advancement of the self-interest of the protesters. ${ }^{218}$ Protests in support of better wages, hours, and working conditions would usually meet that test, ${ }^{219}$ but self-interest was very narrowly defined and, when workers "aim[ed] at a purpose 'one degree more remote" " than extracting a better bargain from the boss, the privilege would frequently vanish. 220 Indeed, objects deemed too "remote" from self-interest to warrant protection even included unionization and the closed shop. ${ }^{221}$ A fortiori, such sympathetic ends as securing the reinstatement of a discharged employee were fatally

216. See, e.g., F. Frankfurter \& N. Greene, The Labor Injunction 2-46 (1930); J. Atleson, supra note 4, at 67-71; R. Gorman, supra note 41, at 1-3; Gorman \& Finkin, supra note 149, at 331-38. The paragraphs that immediately follow draw heavily on The Labor Injunction, which remains the classic account of this body of doctrine. Moreover, as explained infra notes 243-58 and accompanying text, Frankfurter was one of the principal authors of the legislative materials under examination. Accordingly, his understanding of the state of the common law that those materials were designed to alter is of particular interest.

217. See, e.g., Aikens v. Wisconsin, 195 U.S. 194, 204 (1904), quoted in F. Frankfurter \& N. Greene, supra note 216 , at $24 \&$ n.107.

218. F. Frankfurter \& N. Greene, supra note 216, at 26-28; R. Gorman, supra note 41 , at 2 ; J. Atleson, supra note 4 , at $69-70$.

219. F. Frankfurter \& N. Greene, supra note 216 , at $26-27 \&$ n.116 (collecting cases).

220. Id. at 27 (quoting Plant v. Woods, 176 Mass. 492, 505, 57 N.E. 1011,1016 (1900) (Holmes, C.J., dissenting)).

221. As the Massachusetts Supreme Judicial Court explained: "Strengthening the forces of a labor union, to put it in a better condition to enforce its claims in controversies that may afterwards arise with employers, is not enough to justify an attack upon the business of an employer by inducing his employees to strike." Folsom v. Lewis, 208 
infirm. 222

During the early part of this century, the federal courts joined the fray. Applying the then recently adopted Sherman $\mathrm{Act}^{223}$ to labor unions, they ultimately incorporated much of this common-law regime in their efforts to define the prohibited "conspirac[ies] . . . in restraint of trade" and thereby enjoined a broad range of union activities that in their view were insufficiently related to the members' self-interest. ${ }^{224}$ Against this backdrop, Congress in 1914 passed the Clayton Act. ${ }^{225}$ Section 6 of that statute exempted the "lawful" activities of labor unions from the sweep of the antitrust laws, ${ }_{2}{ }^{226}$ and section 20 restricted the issuance of injunctions in all cases "involving, or growing out of, a dispute concerning terms or conditions of employment," prohibiting their use outright against a host of strike and boycott activities. ${ }^{227}$ Together, the provisions constituted a first attempt by Congress to limit the role of the federal judiciary in regulating the use of economic weapons by labor. 228

But the drama was not over. The Supreme Court soon gutted the Clayton Act's would-be labor exemption in Duplex Printing Press Co. $v$. Deering. 229 The employer, a nonunion manufacturer of printing presses, sought to enjoin the machinists union from inducing its members to refuse to handle or repair the employer's products for its customers. ${ }^{230}$ The union, for its part, represented the employees of the target employer's principal competitors, and had accordingly mounted the boycott for the purpose of inducing that employer to enter a collective bargaining agreement and comply with union standards. ${ }^{231}$ The Court sustained the employer's claim and held that sections 6 and 20 of the Clayton Act were merely declarative of existing law, which, as outlined above, made the legality of the protest turn on the extent of the

Mass. 336, 338, 94 N.E. 316, 317 (1911), quoted in F. Frankfurter \& N. Greene, supra note 216 , at 29.

222. F. Frankfurter \& N. Greene, supra note 216 , at $28 \&$ n. 130 .

223. Ch. 647, 26 Stat. 209 (1890) (codified as amended at 15 U.S.C. $\S \S 1-7$ (1982)).

224. See The Developing Labor Law, supra note 43, at 9-12; F. Frankfurter \& N. Greene, supra note 216, at 7-9; R. Gorman, supra note 41, at 621-24. Similarly, the federal courts drew heavily upon this body of doctrine when fashioning the federal common law in diversity cases adjudicated under the rule of Swift v. Tyson, 41 U.S. (16 Pet.) 1 (1842); see F. Frankfurter \& N. Greene, supra note 216, at 11-15.

225. Ch. 323, 38. Stat. 730 (1914) (codified as amended at 15 U.S.C. $\$ \S 12-27$ (1982 \& Supp. 1V 1986)).

226. 15 U.S.C. $\$ 17$ (1982).

227. 29 U.S.C. $\$ 52$ (1982).

228. See F. Frankfurter \& N. Greene, supra note 216, at 154-65; R. Gorman, supra note 41 , at 622 .

229. 254 U.S. 443 (1921).

230. ld. at $462-63$.

231. Id. at 462; id. at 479 (Brandeis, J., dissenting). 
protesters' direct self-interest in its objects or ends. ${ }^{232}$ Specifically, the Court concluded that the boycott at issue could be enjoined because the labor exemption applied only to disputes between an employer and his own employees, and the vast majority of the union's members were not employees of the target employer. ${ }^{233}$ The Court explained that, in enacting the Clayton Act,

Congress had in mind particular industrial controversies, not a general class war. "Terms or conditions of employment" are the only grounds of dispute recognized as adequate to bring into play the exemptions; and it would do violence to the guarded language employed were the exemption extended beyond the parties affected in a proximate and substantial, not merely a sentimental or sympathetic, sense by the cause of dispute. ${ }^{234}$

Justice Brandeis, joined by Justices Holmes and Clarke, dissented.235 Their position on the issue is especially worthy of note because it staked out what eventually became the liberal strategy for taming the labor injunction. ${ }^{236}$ Thus, the dissenters did not reject the notion that protester self-interest was the touchstone of the inquiry. Indeed, they concluded that the Clayton Act had "declare[d] the right of industrial combatants to push their struggle to the limits of the justification of self-interest," 237 and they asserted that the majority was simply wrong on the facts in concluding that the union had an insubstantial interest in eliminating the target employer's nonunion competition. ${ }^{238}$ But the dissenters stressed that it was the role of Congress-not the judiciary-to establish "the limits of the justification of self-interest," and that Congress through the Clayton Act had done so in a manner that precluded injunctive relief against boycotts of the sort at issue in the subject case. ${ }^{239}$

232. Id. at 468-73. To be fair to the Court, this was not an altogether indefensible reading of what Congress had said in the statute itself. Section 6 , for example, stated that the antitrust laws should not be construed to prohibit union members from "lawfully carrying out the legitimate objects" of their unions, I5 U.S.C. $\S$ I7 (1982) (emphasis added), which the Court understood to refer to "objects deemed legitimate under existing law," 254 U.S. at 469 . The dissenters, however, had by far the better of it when it came to what the members of Congress meant - a fact borne out by the adoption a decade later of the Norris-LaGuardia Act. See infra notes 241-63 and accompanying text.

233. 254 U.S. at $47 \mathrm{I}-72$.

234. Id. (emphasis added).

235. Id. at 479 (Brandeis, J., dissenting).

236. See infra notes $254-58$ and accompanying text.

237. 254 U.S. at 488 (Brandeis, J., dissenting).

238. Id.; see also id. at $480-83$ (elaborating the point in the context of the employer's common-law diversity claims against union).

239. Id. at 488.

The [Act] set out certain acts which had previously been held unlawful, whenever courts had disapproved of the ends for which they were performed; it then declared that, when these acts were committed in the course of an industrial dispute, they should not be held to violate any laws of the United States. In other words the Clayton Act substituted the opinion of Congress as to the pro- 
2. The Norris-LaGuardia Act. - In the wake of the Duplex decision and related doctrinal developments, ${ }^{240}$ Congress went back to the drawing board. In 1932 it passed the Norris-LaGuardia Act, which stripped the federal courts of jurisdiction to grant injunctions in a broad range of labor disputes, without regard to whether "the disputants stand in the proximate relation of employer and employee."241 It is useful at this point to turn to a close examination of the drafting of this statute, for it is here that the expression "concerted activities for the purpose of . . . mutual aid or protection," transplanted three years later to section 7 of the Wagner Act, makes its first appearance in American labor law. ${ }^{242}$

The "author" of the legislation was an ad hoc team of lawyers and academics-Felix Frankfurter and Francis Sayre of Harvard, Herman Oliphant of Columbia, Edwin Witte, chief of the Wisconsin Legislative Reference Library, and Donald Richberg, a lawyer from Chicago-first convened in 1928 at the request of a special subcommittee established by the Senate Judiciary Committee. ${ }^{243}$ The individual drafters had substantial experience in the labor field. Oliphant, for example, had previously drafted a bill to outlaw the yellow-dog contract, which was introduced in the Ohio legislature; ${ }^{244}$ Witte had been heavily involved

priety of the purpose for that of differing judges; and thereby it declared that the relations between employers of labor and workingmen were competitive relations, that organized competition was not harmful and that it justified injuries necessarily inflicted in its course.

Id. at 486.

240. See, e.g., Bedford Cut Stone Co. v. Journeymen Stone Cutters' Ass'n, 274 U.S. 37, 53-55 (I927) (authorizing injunction against union's refusal to work on stone cut at nonunion quarries). The legal restrictions on union activities were not limited to secondary boycotts. In the Coronado Coal cases, for example, the Court established a similar objects-based test for evaluating the legality of primary strikes and picketing. Protests aimed at the betterment of wages and working conditions were deemed merely "local" and thus exempt from the congressional regulation of interstate commerce; protests desigued to eliminate nonunion wage competition, however, were deemed an unlawful interference under the antitrust laws. See UMW v. Coronado Coal Co., 259 U.S. 344, 408-09 (I922); Coronado Coal Co. v. UMW, 268 U.S. 295, 310 (I925); see also R. Gorman, supra note 41 , at 623-24 (noting that the two contrasting motives "commonly coexisted and were inseparable," making the antitrust laws "most effective weapons" against organizing activities).

241. Norris-LaGuardia Act, ch. 90, $\S 1-15,47$ Stat. 70, 70-73 (1932) (codified as amended at 29 U.S.C. $\$ \S 101-115$ (1982)). The quoted passage is from $\S 13(\mathrm{c})$ of the Act, 29 U.S.C. $\$ 113$ (c), which defines "labor dispute" and overrules Duplex.

242. Accounts of the expression's origins in Norris-LaGuardia have been thoughtfully rendered elsewhere. See, e.g., Gorman \& Finkin, supra note 149, at 331-46; Lynd, supra note 149, at 726-34; Finkin, supra note 151, at 161-75. Those accounts, however, focus principally upon the significance of the phrase "concerted activities" and do not attempt to trace the source or divine the meaning of "mutual aid or protection."

243. The most thoroughgoing account of the work of this drafting team can be found in Gorman \& Finkin, supra note 149, at 332-35; and see I. Bernstein, The Lean Years: A History of the American Worker, 1920-1933 394-97 (1960).

244. I. Bernstein, supra note 243 , at 394 . 
in the anti-injunction movement on a number of fronts; ${ }^{245}$ and Richberg had served as counsel to various railway unions and as a drafter of the Railway Labor Act. ${ }^{246}$ Frankfurter, for his part, went on to co-author The Labor Injunction, which was to become the leading scholarly attack on the practices of the federal courts in labor cases. ${ }^{247}$

The proposed bill had three provisions of significance here. Section 2 was a declaration of policy; it is there that the phrase "mutual aid or protection" first appeared. ${ }^{248}$ Apparently, the provision had primarily a heuristic purpose; Frankfurter considered it "useful rhetoric . . . intended as an explicit avowal of the considerations moving Congressional action and, therefore, controlling any loyal application of national policy by the courts." 249 The substantive heart of the bill was section 4, which divested the federal courts of jurisdiction to issue injunctions "in cases involving or growing out of any labor dispute to prohibit any person or persons participating and interested in such dispute" from engaging in various strike, picketing, and boycott activities. 250 The term "labor dispute" was, in turn, defined in section 9 of the bill. ${ }^{251}$ In essence, the provision had two components. First, it

245. See T. Schlabach, Edwin E. Witte-Cautious Reformer 52-73 (1969).

246. I. Bernstein, supra note 243 , at 396; Gorman \& Finkin, supra note 149, at 333.

247. See supra note 216 .

248. Whereas under prevailing economic conditions, developed with the aid of governmental authority for owners of property to organize in the corporate and other forms of ownership association, the individual unorganized worker is commonly helpless to exercise actual liberty of contract and to protect his freedom of labor, and thereby to obtain acceptable terms and conditions of employment, wherefore, it is necessary that he have full freedom of association, self-organization, and designation of representatives of his own choosing, to negotiate the terms and conditions of his employment, and that he shall be free from the interference, restraint, or coercion of employers of labor, or their agents, in the designation of such representatives or in self-organization or in other concerled activities for the purpose of collective bargaining or other mutual aid or protection; therefore, the following definitions of, and limitations upon, the jurisdiction and authority of the courts of the United States are hereby enacted.

Frankfurter \& N. Greene, supra note 216, at 280-81 (emphasis added); see also id. at $279 \mathrm{n} . *$ (describing how language was inserted into Senate bill).

249. Id. at 212.

250. Id. at 282-83. In pertinent part, the provision reads:

No court of the United States shall have jurisdiction to issue any restraining order or injunction in cases involving or growing out of any labor dispute to prohibit any person or persons participating and interested in such dispute (as these terms are herein defined) from doing, whether singly or in concert, any of the following acts ....

Id. at 282. The provision then lists a series of nine protected acts, including striking, quitting one's employment, becoming or remaining a member of a labor union, and picketing or otherwise publicizing a labor dispute. Id. at 282-83.

251. Id. at 287-88, which read in pertinent part:

When used in this Act, and for the purposes of this Act

(a) A case shall be held to involve or to grow out of a labor dispute if the case involves persons who are engaged in the same industry, trade, craft, or occupa- 
overruled Duplex and defined "labor dispute" broadly to include any employment controversy "regardless of whether or not the disputants stand in the proximate relation of employer and employee."252 More importantly here, the provision placed an outer limit on the meaning of the term; to enjoy immunity from injunctive interference, a controversy had to "involve[] persons who are engaged in the same industry, trade, craft, or occupation."253

In The Labor Injunction, Frankfurter described the structure adopted by the drafters as "an attempt to recognize frankly that the central problem of the law of industrial relations is to determine the purposes that justify combination of laborers by marking the outposts of the concept of 'self interest.' "254 He explained that the bill's definition of the term "labor dispute" "settle[d] all of these questions so far as application for equitable relief is concerned. Immunity from injunctions extends to all the categories that we have described, save alone as to persons who are not engaged in the same industry with the complainant."255 This definition, Frankfurter concluded:

thus registers the implications of interdependence within American industry. It permits the collaboration of efforts between unions whom substantial interests make natural allies. It withholds immunity from the chancellor's decree at a point where combination aims to include unions that have no eco-

tion; or who are employees of the same employer; or who are members of the same organization of employers or employees .... .

(b) A person or association shall be held to be a person participating and interested in a labor dispute if relief is sought against him or it and if he or it is engaged in the same industry, trade, craft, or occupation in which such dispute occurs, or is a member, officer, or agent of any association of employers or employees engaged in such industry, trade, craft, or occupation.

(c) The term "labor dispute" includes any controversy concerning terms or conditions or employment, or concerning the association or representation of persons in negotiating, fixing, maintaining, changing, or seeking to arrange terms and conditions of employment, or concerning employment relations, or any other controversy arising out of the respective interests of employer and employee, regardless of whether or not the disputants stand in the proximate relation of employer and employee.

Id. In the bill ultimately adopted by Congress, this provision appears as ch. $90, \S 13,47$ Stat. 70, 73 (I932) (codified at 29 U.S.C. \& I 13 (1982)).

252. F. Frankfurter \& N. Greene, supra note 216 , at 288.

253. Id. at 287.

254. Id. at 2I5. Frankfurter elaborated the point thus:

How far laborers may combine to strive for concessions that are not of immediate benefit to them but which strengthen union organization; how far a union in one craft may use its power to achieve the unionization of non-union plants within the same craft; how far a union of one craft may exert its power in aid of unions of another craft, and how dependent one craft must be upon the other to justify co-operative tactics-these and like issues are the crucial ones.

Id. at 215-I6.

255. Id. at 216 (footnote omitted). 
nomic bond but only a sympathetic interest. ${ }^{256}$

It is clear then that Frankfurter had taken up the cudgels for the "liberal" strategy against the labor injunction first espoused by Justice Brandeis and the other dissenters in Duplex: an embrace of a substantive regime of self-interest, to be sure, but one sensitive to "the implications of interdependence within American industry" and regulated by legislative line-drawing rather than any judicial inquiry into the supposed legitimacy of the objects of a challenged protest. ${ }^{257}$ And the line drawn was a definition of "labor dispute" that in effect prohibited injunctions in all controversies "save alone as to persons who are not engaged in the same industry with the complainant."258

The bill proposed by the ad hoc drafting team was adopted by Congress with only minor revision as the Norris-LaGuardia Act. ${ }^{259}$ It is not at all clear from the floor debates what the members of Congress made of the liberal critics' philosophical commitment to self-interest. What is clear, however, is that the sponsors of the legislation were furious with the courts for "denatur[ing], emasculat[ing], and tortur[ing]" the Clayton Act's labor exemption and shared Frankfurter's view that the judiciary should be put out of the business of evaluating protester purposes once and for all. ${ }^{260}$

In a nutshell, then, the Clayton and Norris-LaGuardia Acts were not adopted simply to immunize strikes and other protest activities from the antitrust laws or the labor injunction generally. To a certain extent, labor already enjoyed such immunity, so long as its efforts were aimed at securing better wages, hours, and working conditions-tbat is, at serving its direct and narrowly defined self-interest. Rather, the principal siguificance of the federal legislative response is that it represented a specific congressional attempt to repeal the judicial limitations adopted in the name of self-interest on the prerogative of working people to engage in protest activities.

To be sure, this point is open to the objection that Congress did not so much reject the idea of "self-interest" as it did repudiate the courts' ridiculously narrow construction of it; the Supreme Court's characterization of the boycott in Duplex-which was, after all, an un-

256. Id. at 217 (footnote omitted).

257. See supra notes $235-39$ and accompanying text. It is surely no coincidence that Frankfurter and Greene dedicated The Labor Injunction to Mr. Justice Brandeis. On Brandeis's influence upon Frankfurter generally, see B. Murphy, The Brandeis/ Frankfurter Connection (1982).

258. F. Frankfurter \& N. Greene, supra note 216, at 216.

259. See Gorman \& Finkin, supra note 149, at 334-36.

260. 75 Cong. Rec. 5470 (1932) (remarks of Rep. Browning). As the Supreme Court recently observed, "The congressional debates over the Norris-LaGuardia Act disclose that the Act's sponsors were convinced that the extraordinary step of divesting federal courts of equitable jurisdiction was necessary to remedy an extraordinary problem." Burlington N.R.R. v. Brotherhood of Maintenance of Way Employes, 481 U.S. 429,437 (1987) (citing various statements from legislative history). 
sheltered effort to eliminate competition from a nonunion employeras merely "sentimental or sympathetic"261 is disingenuous at best. As suggested earlier, the contemporaneous liberal critique of the jurisprudence at issue, articulated by the dissenters in Duplex and vigorously embraced by Frankfurter, assumed the propriety of a regime of selfinterest and simply held that the common-law cases were wrong on the facts. Indeed, Congress at least tacitly accepted this regime by adopting a definition of the term "labor dispute" that, in Frankfurter's words, denied labor the protection of the new anti-injuction statute "at a point where combination aims to include unions that have ... only a sympathetic interest."262 But the fact remains that the means Congress selected to accomplish this end were to provide an express statutory limit on protest activity and thus to get the courts altogether out of the business of evaluating the legitimacy of the objects of labor protests. ${ }^{263}$

3. Mutualism and Section 7. - Quite apart from the general policy thrust of the Norris-LaGuardia Act, there is ample evidence that the contemporaneous understanding of the expression "mutual aid or protection"- contained in section 2 of that statute and incorporated verbatim three years later in the Wagner Act's section 7-was unburdened by narrow notions of self-interest. Frankfurter and the other members of the ad hoc drafting team did not, after all, get the expression "mutual aid or protection" from thin air. The phrase almost surely had its genesis in the working class and trade union philosophy of "mutualism" and "mutual support," brilliantly recaptured in labor historian David Montgomery's accounts of the workplace struggles in the late nineteenth and early twentieth centuries:

[Early in this era, employers] in every industry tried to reduce their production costs by lowering wages. That effort was often challenged by workers, whose powers of resistance were strengthened by familial, gender, ethnic, and community loyalties .... The contest so pervaded social life that the ide-

261. Duplex Printing Press Co. v. Deering, 254 U.S. 443, 472 (1921).

262. F. Frankfurter \& N. Greene, supra note 216, at 217.

263. It is in the light of this history that the Supreme Court has repeatedly turned back efforts to limit the scope of Norris-LaGuardia's anti-injunction provisions to cases in which the challenged protest is motivated by the protesters' economic self-interest. See, e.g., Burlington N.R.R., 481 U.S. at 440-43 (rejecting interpretation of NorrisLaGuardia Act that would confine controversy "grow[ing] out of a labor dispute" to protest activities that "further the union's economic interest in a labor dispute" "); Jacksonville Bulk Terminals, Inc. v. International Longshoremen's Ass'n, 457 U.S. 702, 713-14 (1982) (rejecting claim that "labor dispute," within meaning of NorrisLaGuardia Act, "exists only when the Union's action is taken in its own "economic selfinterest" " and holding that Act prohibited injunctive relief against boycott motivated by political considerations). Indeed, what is striking about these cases is the persistence of the efforts to return to precisely the legal regime that prompted the enactment of Norris-LaGuardia. Perhaps this is what my colleague Pat Gudridge means by his observation that legislation encodes conflict. See Gudridge, Legislation in Legal Imagination: Introductory Exercises, 37 U. Miami L. Rev. 493 (1983). 
ology of acquisitive individualism, which explained and justified a society regulated by market mechanisms and propelled by the accumulation of capital, was challenged by an ideology of mutualism, rooted in working-class bondings and struggles. ${ }^{264}$

As the quoted passage suggests, this "mutualism" was not just "selfinterest" for a different group of "selves"; in Montgomery's words, it was a common experience of working people that "all attachments were rooted in the shared presumption that individualism was appropriate only for the prosperous and wellborn."265 Rather, it represented a forthright embrace of an ethic of solidarity "rooted in working-class bondings and struggles" 266 and evident in, among other things, the proliferation of sympathy strikes during this era. ${ }^{267}$

It is not implausible to infer that individuals like Frankfurter and Witte, well-versed as they were in the labor field, would have been conversant with the rhetoric, philosophy, and recent history of the labor movement. Indeed, it seems quite unlikely that their choice of the expression "mutual aid or protection"-grounded as it was in the lives, experiences, and beliefs of the working people whose cause they sought to further-was just a remarkable coincidence. ${ }^{268}$

264. D. Montgomery, supra note 9 , at 171 .

265. 1d. at 2. For example, Montgomery quotes contemporary labor reformer George McNeill: "The organization of laborers in Trades Unions recognizes the fact that mutualism is preferable to individualism.' " Id. at 4 (quoting McNeill, Philosophy of the Labor Movement, in Trades Council of New Haven, llustrated History of the Trades Council of New Haven 212-13 (1899)).

266. 1d. at 171. Professor Atleson traces this self-conscious "impetus toward mutual assistance" from the motto of the Knights of Labor ("An injury to one is the concern of all.") to the CIO pledge "to help and assist all brothers in adversity, and to have all eligible workers join the union that we may all be able to enjoy the fruits of our labor; and that I will never knowingly wrong a brother or see him wronged, if I can prevent it." J. Atleson, supra note 4, at 206 n.13. For a more recent example, see G. Friedmann, The Anatomy of Work 79-80 (196I) ("trade unionism is for many workers not only, or even essentially, a defence of their interests but rather a visible expression, a concrete symbol, of solidarity, of a network of human relationships within the industrial jungle").

267. See D. Montgomery, Workers' Control in America: Studies in the History of Work, Technology, and Labor Struggles 18-27 (1979). See, in particular, id. at 22:

Eugene V. Debs was to extoll this extreme manifestation of mutuality [i.e., the sympathy strike] as the "Christ-like virtue of sympathy," and to depict his own Pullman boycott, the epoch's most massive sympathetic action, as an open confrontation between that working-class virtue and a social order which sanctified selfishness.

268. There is some tension between this assumption and Frankfurter's view that the Norris-LaGuardia Act "withholds immunity from the chancellor's decree at the point where combination aims to include unions that have no economic bond but only a sympathetic interest." F. Frankfurter \& N. Greene, supra note 2I6, at 217; see supra note 256. But, as explained above, the statute was carefully drafted to achieve that end through its definition of "labor dispute." See supra text accompanying notes 248-58. Indeed, it seems highly unlikely that the drafters would have adopted the expression "mutual aid or protection" in a policy declaration consciously designed to "contro[1] any loyal application of national policy by the courts," F. Frankfurter \& N. Greene, supra 
There is further evidence of the expression's roots in the labormovement. Professors Gorman and Finkin have noted that it was a prominent labor official who secured its inclusion in section 7(a) of the National Industrial Recovery Act of $1933^{269}$ - the immediate, albeit toothless, precursor to section 7 of the Wagner Act. ${ }^{270}$ Thus, Congress had been considering a version of section 7(a) that would have required industrial fair competition codes to contain a condition that "employees shall have the right to organize and bargain collectively through representatives of their own choosing."271 Testifying before the House, AFL President William Green encouraged Congress to amend the bill to include the following language: "And shall be free from the interference, restraint, or coercion of employers of labor, or their agents, in the designation of such representatives or in self-organization or in other concerted activities for the purpose of collective bargaining or other mutual aid or protection." "272 The final bill included this language, but was struck down with the rest of that legislation by the Supreme Court in the famous Schechter Poultry case.273

Two years later, with virtually no relevant discussion among the members of Congress, the "concerted activities for the purpose of ... mutual aid or protection" language was incorporated in section 7 of the Wagner Act as well. ${ }^{274}$ Significantly, the only debate on the provision was Representative Blanton's objection that the right to "engage in concerted activities for mutual aid" was "not restricted to an em. ployer's own employees," 275 raising the spectre of a Duplex-style limitation. Congress, however, rejected his argument and ultimately adopted a definition of "labor dispute" for the Wagner Act that eliminated even the "same industry" limitation imposed by Norris-LaGuardia. ${ }^{276}$

note 216 , at 212 , if to do so would have invited the courts to undertake an independent inquiry into the "outposts of the concept of 'self-interest" " on a case-by-case basis, id. at 215. In any event, as shown at infra text accompanying note 276, the Wagner Act Congress did not adopt Norris-LaGuardia's restrictive definition of "labor dispute."

269. Ch. 90, 48 Stat. $195^{\circ}$ (1933).

270. See Gorman \& Finkin, supra note 149 , at 337-38.

271. Id. at 337.

272. Id. (quoting National Industrial Recovery: Hearings on H.R. 5664 Before the House Comm. on Ways and Means, 73d Cong., lst Sess. 117 (1933) (statement of William Green)).

273. Schechter Poultry Corp. v. United States, 295 U.S. 495 (1935). On the fascinating genesis of $\S 7$ (a), as told in the words of one of the principal authors of both the NIRA and the Wagner Act, see Casebeer, Holder of the Pen: An Interview with Leon Keyserling on Drafting the Wagner Act, 42 U. Miami L. Rev. 285, 299-303 (1987).

274. N.L.R.A., ch. 372,49 Stat. 449 (1935) (codified as amended at 29 U.S.C. $\S 157$ (1982)).

275. 79 Cong. Rec. 9701 (1935) (remarks of Rep. Blanton), reprinted in 2 Legislative History of the National Labor Relations Act, 1935, 3157 (1935).

276. Compare Norris-LaGuardia Act $\S 13($ a)-(c), 29 U.S.C. $\S 113(a)$-(c) (1982) (provisions limiting injunction immunity to labor disputes involving parties in "the same industry, trade, craft, or occupation") with N.L.R.A. \& 2(9), 29 U.S.C. § 152(9) (1982) (placing no such limitation on labor disputes governed by the Act). 
4. Section 7 and Taft-Hartley. - $\ln$ the years that followed the enactment of the Wagner Act, the Board and the courts consistently gave section 7 a construction consonant with the view that Congress had intended the expression mutual aid or protection to cover a wide range of sympathetic protest activity. ${ }^{277}$ Indeed, it is apparent that members of Congress assumed that this was the state of the law when they considered and adopted the Taft-Hartley amendments to the Act some twelve years later, in 1947.

Thus, the House passed a bill that would have expressly excluded from the coverage of section 7 "any sympathy strike, jurisdictional strike, monopolistic strike, or illegal boycott, or any sit-down strike or other concerted interference with an employer's operations conducted by remaining on the employer's premises." 278 The accompanying report explained that the purpose of the express exclusion for sit-down strikes and similarly disruptive conduct was to "writ[e] into the act" the then-current state of decisional law. ${ }^{279}$ By contrast, the bill's treatment of sympathy strikes and boycott activities was assertedly designed to

277. See, for example, the numerous cases from this period that upheld $\S 7$ protection in the absence of any evident self-interest on the part of the protesters, such as those involving protests over the discharge of a fellow worker, Firth Carpet Co. v. NLRB, 129 F.2d 633, 635-36 (2d Cir. 1942); NLRB v. Biles Coleman Lumber Co., 98 F.2d 18, 23 (9th Cir. 1938); those involving "sympatheti[c]" refusals by non-unit employees to perform struck work, Columbia Pictures Corp., 82 N.L.R.B. 568, 629-30 \& n.57 (1949), enforcement denied on other grounds sub nom. NLRB v. Warner Bros. Pictures, 191 F.2d 217 (9th Cir. 1951); Montgomery Ward \& Co., 64 N.L.R.B. 432, 444-46 (1945), enforcement denied on other grounds, 157 F.2d 486 (8th Cir. 1946); Rapid Roller Co. v. NLRB, 126 F.2d 452, 460-61 (7th Cir.), cert. denied, 317 U.S. 650 (1942); those involving other forms of support by non-unit employees, Montag Bros., 51 N.L.R.B. 366, 370-72 (1943) (refusal to cross picket line), enforced, 140 F.2d 730 (5th Cir. 1944); Club Troika, Inc., 2 N.L.R.B. 90, 94 (1936) (resignation in support of discharged employees); and those involving support for the union efforts of the employees another employer, NLRB v. J.G. Boswell Co., 136 F.2d 585, 594-96 (9th Cir. 1943); Fort Wayne Corrugated Paper Co. v. NLRB, 111 F.2d 869, 873-74 (7th Cir. 1940). See generally Hazel-Atlas Glass Co., 34 N.L.R.B. 346, 414-15 \& n.102 (1941) ("[i]t is well recognized . . . that members of one union[,] or even non-union employees, may join sympathetically in the activities of another union in which they are not eligible for memberhsip, or may even assist the employees of another employer, without relinquishing the protection afforded by the Act"), enforcement denied in relevant part on other grounds, 127 F.2d 109 (4th Cir. 1942).

278. H.R. 3020, 80th Cong., 1st Sess. $\S 12(a)(3)(A)(1947)$, reprinted in 1 Legis. Hist. 1947, supra note 119 , at 204-05 (declaring such conduct "unlawful concerted activities"); see id. $\S 7$ (a), reprinted in 1 Legis. Hist. 1947, supra note 119 , at 176 (excluding "unlawful concerted activities" from $\S 7$ protection); see also id. § 2(13)-(16), reprinted in 1 Legis. Hist. 1947, supra note 119, at 168-70 (defining "sympathy strike" and related terms). The bill also permitted employers to seek damages and injunctive relief against individuals who engaged in such conduct. Id. $\$ 12$ (b), reprinted in 1 Legis. Hist. 1947, supra note 119, at 206 (damages); id. $\$ 12$ (c), reprinted in Legis. Hist. 1947, supra note 119, at 206-07 (exempting enumerated activities from the anti-injunction provisions of $\S 4$ of Norris-LaGuardia Act, 29 U.S.C. $\S 104)$.

279. H. Rep. No. 245, 80th Cong., 1st Sess. 27-28 (1947), reprinted in 1 Legis. Hist. 1947, supra note 119 , at 318-19 (emphasis omitted) (citing, inter alia, NLRB v. 
"remov[e] the immunities that the present laws confer upon persons who engage in [such conduct]." 280 This strongly suggests that the drafters were well aware of the prevailing practice of the Board and the courts with respect to sympathetic actions, ${ }^{281}$ and sought to change it.

Significantly, however, the House proposal was rejected in conference in favor of a bill that left intact the Wagner Act's definition of protected activities under section 7.282 To be sure, section $8(b)(4)$ of the final bill placed drastic limitations on the permissible scope of sympathetic actions by prohibiting many forms of the secondary boycott. ${ }^{283}$ But there is no indication in the legislative history that Congress sought to proscribe sympathetic actions apart from those specifically prohibited by that provision, ${ }^{284}$ nor to alter the settled understanding of the meaning of "mutual aid or protection."

\section{B. The Peter Cailler Case}

The contemporary search for self-interest in section 7 cases can be traced to the endlessly cited Peter Cailler opinion, ${ }^{285}$ quoted at the outset of the Article and written by Judge Learned Hand. ${ }^{286}$ The conventional understanding of the passage is that it offers section 7 protection on the basis of a "promise of reciprocal benefit" to those whose aid is given or sought. Ever since Peter Cailler, the Board and the courts have relied upon some variant of this promise of reciprocity to justify legal protection for a wide range of workplace protests. But a review of Peter

Fansteel Metallurgical Corp., 306 U.S. 240, 253-59 (1939) (sit-down strike that involved seizure of plant and sabotage held uprotected by the Act)).

280. Id. at 23-24, reprinted in 1 Legis. Hist. 1947, supra note 119, at 314-15.

281. See supra note 277 (citing cases); see also Getman, supra note 39, at 1227 n.137 ("The Taft-Hartley Act debates indicated the belief of Congress that secondary economic pressure, as well as refusals to cross picket lines, were protected activity under the Wagner Act.").

282. See Comparison of the National Lahor Relations Act of 1935 with Title $I$ of the Labor Management Relations Act of 1947, 2 Legis. Hist. 1947, supra note 119, at 1666. Two changes were made elsewhere in the text of the provision, neither of them relevant here. See supra note 137.

283. See N.L.R.A. § 8(b)(4), 29 U.S.C. § 158(b)(4) (1982); see also id. § 8(e), 29 U.S.C. $\S 158(\mathrm{e})$ (related provision subsequently adopted in Landrum-Griffin amendments prohibiting hot-cargo agreements).

284. As the Supreme Court has on more than one occasion observed, "The NLRA does not contain a 'sweeping prohibition' of secondary activity; instead it 'describes and condemns specific union conduct directed to specific objectives.' " Burlington N.R.R. v. Brotherhood of Maintenance of Way Employes, 481 U.S. 429, 448 (1987) (quoting Carpenters v. NL.RB, 357 U.S. 93, 98 (1958)). Indeed, Congress expressly exempted from the sweep of Taft-Hartley's anti-secondary provision the classic form of sympathetic activity: the refusal to cross a stranger picket line. See N.L.R.A. $§ 8(b)(4), 29$ U.S.C. $\$ 158(b)(4)$. See generally Axelrod, supra note 39, at 627-29 (discussing history of 8 (b)(4)'s proviso).

285. NLRB v. Peter Cailler Kohler Swiss Chocolates Co., 130 F.2d 503 (2d Cir. 1942).

286. See supra text accompanying note 7 . 
Cailler in its factual context shows that Hand held no brief for naked self-interest; indeed, a closer look at the language of the opinion itself suggests that the opposite is the case.

Cailler was a producer of milk chocolate and related products, and it relied on a particular dairy farmers' cooperative for the bulk of its considerable milk requirements. The Dairy Farmers Union, a competitor of Cailler's supplier, called a "milk holiday" in order to drive up the price of milk by withholding its own supply from the market. ${ }^{287}$ When Cailler assisted its supplier in combating the "holiday" tactic, the union representing Cailler's employees passed a resolution expressing their solidarity with and support for the Dairy Farmers Union, and the resolution was published in the local papers. ${ }^{288}$ In retaliation, Cailler fired the union activist perceived to be the culprit behind the resolution. The Board found the resolution and its publication protected by section 7 and accordingly held that the retaliatory discharge violated the Act. The court of appeals affirmed. ${ }^{289}$

What is interesting about Peter Cailler, however, is that it is not just another case reinterpreting a gesture of solidarity as self-interested. It is true that the Cailler employees were-for all that appears in the case reports-moved primarily by their concern for others (the Dairy Farmers Union) and not for themselves. ${ }^{290}$ But there was good reason why that concern, standing alone, might have rendered section 7 protection problematic in the circumstances of the case: The members of the Dairy Farmers Union were farmers and therefore not "employees" within the meaning of the Act. ${ }^{291}$ Accordingly, as the court of appeals

287. $130 \mathrm{~F} .2 \mathrm{~d}$ at $504-05$.

288. The resolution read:

Whereas [ $t$ ] hese farmers have banded together in the DAIRY FARMERS UNION, and succeeded, to some measure, in lifting their yoke of oppression; and

Whereas [ $t$ ]he controlling powers and trusts have employed every vile and vicious means in their efforts to stop organization and nullify the effectiveness of the DAIRY FARMERS UNION; and

Whereas [t]he Peter Ca[i]ll[e]r Kohl[e]r Company, whether intentionally or unintentionally, aided and abetted the forces opposed to the DAIRY FARMERS UNION during the strike of $1939 \ldots$. .

Now, therefore, be it

Resolved, [t]hat the workers of the Peter $\mathrm{Ca}[\mathrm{i}] 11[\mathrm{e}] \mathrm{r}$ Kohl[e]r Co. register their protest to the management of this company on their action in regards to the 1939 strike of the DAIRY FARMERS UNION; and be it further

Resolved, [ $t$ ] hat these workers here assembled go on record for complete and unqualified solidarity with the DAIRY FARMERS UNION; and be it further Resolved, [ $t$ ] hat a copy of this resolution be sent to [the] manager of the Peter $\mathrm{Ca}[\mathrm{i}] \mathrm{ll}[\mathrm{e}] \mathrm{r}$ Kohl[e]r Co., and additional copies to the local press, [to the] president ... and to the officers of the ... Dairy Farmers Union.

Id. at $505 \mathrm{n} .1$.

289. Id. at 504-06.

290. See supra note 288 (text of their resolution).

291. 130 F.2d at 505-06. Indeed, even if they were the farmers' employees, they 
noted, the language of section 7-which literally protects only activities for the "mutual aid or protection" of statutory "employees"-would have made it somewhat difficult to justify protecting the offending resolution for the farmers' sake. ${ }^{292}$

It was in that context, then-where the statute by its terms seemed to preclude the protection, since the protest beneficiaries were outside the Act-that the "promise of reciprocal benefit" analysis was first employed. And in that context, it was not only a prudent gambit as a matter of doctrinal analysis; it was also a quite plausible one on the facts. For the Dairy Farmers Union, as a principal competitor of Cailler's leading milk supplier, was very likely to be in a better position to return the favor and aid the Cailler employees in some future dispute of their own than, say, the underpaid masses were ever likely to be in a position to assist the authors of the newsletter in Eastex. ${ }^{293}$

Peter Cailler may be misunderstood in a second, subtler sense as well. Judge Hand's analysis did not, after all, stop with his invocation of the promise of reciprocity. Indeed, the heart of his claim may well have been the clause that follows the one we have been examining:

The rest know that by their action each one of them assures himself, in case his turn ever comes, of the support of the one whom they are all then helping, and the solidarity so established is "mutual aid" in the most literal sense, as nobody doubts. ${ }^{294}$

would be outside the Act since it expressly excludes "agricultural laborer[s]" from its protection. N.L.R.A. $\S 2(3), 29$ U.S.C. $§ 152(3)$ (1982).

292. 130 F.2d at 505. The employer in Hendricks made a similar argument with respect to the disabled Lloyd Hadley, the protest beneficiary in that case. See supra notes 10-16 and accompanying text. Hendricks contended that Hadley's injury made him the functional equivalent of a retired employee-one who had "ceased work without expectation of further employment"-and therefore placed him outside the statutory definition of "employee" as construed in Allied Chem. \& Alkali Workers of Am., Local Union No. 1 v. Pittsburgh Plate Glass Co., 404 U.S. 157, 168 (1971), discussed supra notes 184-213 and accompanying text. The Board rejected the argument, both on the facts, 236 N.L.R.B. at 1620 n.16 ("further employment" for Hadley was, after all, "precisely what the [offending] petition sought"), and on the underlying premise that the employees at Hendricks were acting only in the interest of Hadley. Id. at 1620; see supra text accompanying note 16 . The court of appeals, on the first petition for review, agreed, relying principally on the latter ground, 603 F.2d 25, $27 \&$ n.2 (7th Cir. 1979), and the issue was not raised again thereafter.

Ironically, but not coincidentally, the basis for the exclusion of retired employees is itself of a piece with the search for self-interest. See supra notes 184-213 and accompanying text (discussing Allied Chemical).

293. See supra notes $17-26$ and accompanying text.

294. 130 F.2d at 505-06 (emphasis added). Hand continued, expressing the contemporaneous view that $\S 7$ broadly covered labor solidarity:

So too of those engaging in a "sympathetic strike," or secondary boycott; the immediate quarrel does not itself concern them, but by extending the number of those who will make the enemy of one the enemy of all, the power of each is vastly increased. ... It is true that in the past courts have often failed to recognize the interest which each might have in a solidarity so obtained . . . but it seems to us that the [A]ct has put an end to this. 
In the italicized passage, Judge Hand seems to suggest that the requisite "mutual aid" lies not in the promise of reciprocal benefit itself, but rather in the "solidarity" that is "established" by workplace struggles of the sort fomented by the "workman's separate grievance." This view of Hand's reasoning would, of course, bring it in line with the contemporaneous understanding of "mutual support" described earlier-as an idea born of working-class experience, at odds with the crude individualism suggested by the mere promise of reciprocity, and steeped in notions of community and "brotherhood."295

Contemporaneous readings of Peter Cailler by the Board and the courts were consistent with this view. Rather than going through the difficulty of explaining the protesting employees' conduct in terms of some benefit to themselves, they seem to accept without hesitation that workers simply helping other workers was what "mutual aid" was all about."296 But the "tit-for-tat" version of Peter Cailler caught on and stuck, assuming an almost formulaic quality in later cases. And, like the more familiar Hand formula we learn in first-year Torts, 297 it has spawned an analytical construct that has replaced a richer understand-

\section{Id. at 506 (citations omitted).}

295. See supra notes 264-67 and accompanying text. It is here, then, that I part company with Staughton Lynd's excellent piece on $\$ 7$ rights, Lynd, Communal Rights, 62 Tex. L. Rev. 1417, I427 (I984):

Hand's rationale misses something crucial to the right to engage in concerted activity. I do not scratch your back only because one day I may need you to scratch mine. Labor solidarity is more than an updated version of the social contract through which each individual undertakes to assist others for the advancement of his or her own interest.

Although Lynd's critique of the "promise of reciprocal benefit" is on the mark, I think that Judge Hand might have fully agreed. See also J. Atleson, supra note 4, at 76-77 (noting that Hand "stressed employee interest 'in a solidarity so obtained" ") (quoting Peter Cailler, I30 F.2d at 506).

296. See, e.g., Carter Carburetor Corp. v. NLRB, 140 F.2d 7I4, 718 (8th Cir. 1944) ('[Section 7's] 'mutual aid' and 'concerted activities' include, we think, the right to join other workers in quitting work in protest over the treatment of a coemployee, or supporting him in any other grievance connected with his work or his employer's conduct" (citing Peter Cailler, 130 F.2d 503)). To the same effect, see llinois Bell Tel. Co., 88 N.L.R.B. 1171, 1176 \& nn.18-19 (I950), enforcement denied, 189 F.2d I24 (7th Cir.), cert. denied, 342 U.S. 885 (I951):

The general concern of employees with mutual aid and support in their efforts to improve their working conditions, even when not directed to the immediate achievement of economic benefit for themselves, has long been regarded as ... a protected interest [under $\S 7$ 7]. This concern is traditionally expressed in the form of respect for the picket lines of striking unions, and a refusal to cross such picket lines has repeatedly been held by the Board and the courts to be a kind of concerted activity against which an employer may not retaliate by discriminatory measures.

(citing Peter Cailler and collecting cases) (footnote omitted). The decision of the Seventh Circuit rejecting the Board's view is described at supra note 35.

297. See United States v. Carroll Towing Co., I59 F.2d 169, I73 (2d Cir. I947) ("if the probability be called $\mathrm{P}$; the injury, $\mathrm{L}$; and the burden [of adequate precautions], B; liability depends upon whether B is less than L multiplied by P: i.e., whether B $<$ PL"). 
ing of social interests and aspirations with a rigid, impoverished set of assumptions about the wellsprings of human behavior. ${ }^{298}$

\section{Self/Others in Context: Mutualism and the Other "Other"}

\section{"Why is the legal conception of the relation between employer and employee so at variance with the common knowledge of mankind?"299}

We spend most of our waking hours at a place of work. Wherever we toil-in a factory, a mine, an office, a classroom-our working colleagues often count as among the most important people in our lives. We depend upon them, and they upon us, not only to perform their part in our productive tasks, but as well to share thoughts, opinions, and friendship. What they do with us, and for us, and even to us, looms large in our individual and collective experience of social life. ${ }^{300}$

298. The reference is, of course, to Law and Economics. For an example in the labor area, compare Leslie, Labor Bargaining Units, 70 Va. L. Rev. 353, 355 (1984) ("Because all members of a union share the costs of securing a good, the union is unlikely to seek a good that benefits only a single member.") with the cases discussed above in Parts I and II (in which unions repeatedly seek "goods that benefit[] only a single member"); see also supra notes 184-213 (discussing Allied Chemical, a case in which a union repeatedly sought goods that benefited only those who had retired from the bargaining unit). To be fair, Professor Leslie has undertaken an ambitious and impressive economic analysis of labor law that has highlighted many of the conceptual and empirical inadequacies of simple price theory as applied to the labor context. Perhaps more of us would be willing to immerse ourselves in this internal critique if we did not fear that to "drink the water" of economic analysis is to assume its questionable first premises. See, e.g., Kelman, Misunderstanding Social Life: A Critique of the Core Premises of "Law and Economics," 33 J. Legal Educ. 274, 277-78 (1983).

299. 75 Cong. Rec. 4915 (1932) (remarks of Senator Robert F. Wagner, Sr., quoting Roscoe Pound, then Dean of Harvard Law School, during floor debates on the Norris-LaGuardia Act).

300. Labor historians and social scientists have frequently noted the social cohesion that is fostered by workplace life. In addition to the work of David Montgomery, supra note 9, a classic example is Frank Tannenbaum's description of the effects on working people of the Industrial Revolution:

They worked together at the same bench, inside the same mill or mine, struggled with the same refractory materials, and were dependent upon one another's co-operation. . . . The same process that had gathered these laborers together had forged a "society" in which a sense of identity became inevitable. ... Their mutual association and experience, their similar skills, their relationship to the work bench, the tools they used, and the materials with which they worked gave them a common language.... They shared the special points of pride and shame that can have only specific and local meaning. [Their experience] gave them a common, if local, vocabulary.

F. Tannenbaum, A Philosophy of Labor 59-60 (1952). To the same effect, see R. Blauner, Alienation and Freedom: The Factory Worker and His Industry 24-25 (1964) (suggesting that workplace relationships provide "a center of belongingness and identification, which mitigates feelings of isolation"); W. Kornblum, Blue Collar Community 36 (1974) (concluding that work in the South Chicago steel mills led to "personal attachments" that "often cut across the racial, ethnic, and territorial groupings which may divide men in the outside community"); The Politics of Work and Occupations 169 (G. Esland \& G. Salaman eds. 1980) (describing the "joy in co-operation" and "sense of 
Most of us also share an experience of common vulnerability to those who serve as our supervisors, our managers, and-particularly in a professional setting, like a law firm or a faculty-our senior colleagues. And when they decide to discharge, discipline, or otherwise harm one of us, and we believe that decision is unjust, we may well have the courage to protest and express our support for our working colleague's cause. What moves us to do so, notwithstanding the obvious risk to our own job security? No doubt self-interest does play a large part. What the boss does to you today, he may do to me tomorrow. Accordingly, if 1 plight my troth with you in the service of your cause, you may be all the more likely to assist me in the future, should I find myself in the same fix. Similarly, and especially if we work together in a relatively bureaucratic institution, I may well want you to "win" your case now so that I may invoke your precedent in mine later.

But the range of motives for joining a workplace protest is surely much broader. As the cases explored in the earlier sections suggest, there is often more to our connection with our working colleagues than the mere fact that we work shoulder-to-shoulder in pursuit of a living; we should expect some measure or mix of love, empathy, solidarity, or commitment to principle to come into play as well. Recall, for example, the words of the courageous petition calling for the reinstatement of the disabled Hadley in the Hendricks case: "[O]ther people do matter and Lloyd Hadley matters, to us and to many other people."301 Staughton Lynd has argued eloquently that employees form "families-

team membership" among fellow employees); Coyle; Women at Farah: An Unfinished Story, in A Needle, A Bobbin, A Strike 256-57 (J. Jensen \& S. Davidson, eds. 1984) (describing social relations among strikers at Farah).

The solidarity-enhancing effects of work can, of course, be overstated. The literature acknowledges that attachments among workers are often superficial and, in any event, punctuated by conflict and dispute. See, e.g., M. Burawoy, Manufacturing Consent: Changes in the Labor Process Under Monopoly Capitalism 67 (1979) (suggesting that "management-worker conflict is turned into competitiveness and intragroup struggles as a result of the organization of work"); D. Halle, America's "Working Man": Work, Home, and Politics Among Blue-Collar Property Owners 180-85 (1984) (describing the functions of "joking relations" and "ritual insults" in the workplace); see also S. Perlman, A Theory of the Labor Movement 125-41 (1970) (describing struggle within the early twentieth century labor movement that led to the development of business unionism). See generally Gabel \& Harris, Building Power and Breaking Images: Critical Legal Theory and the Practice of Law, 11 N.Y.U. Rev. L. \& Soc. Change 369, 371 (1982-83) (" $[t]$ he predominance of hierarchy in both public and private life leads to a profound loss of th[e] sense of social connection because it breaks down any possibility of real community, and forces people into a life-long series of isolating roles and routines within which they are unable to fully recognize one another in an empowering and mutually confirming way"). At the same time, a perceptive analysis of the future of workplace relations suggests that "team" and "group" work in modern cybernetic settings may create even more opportunities for employee cohesion than was evident in traditional hierarchical contexts. See L. Hirschhorn, Beyond Mechanization: Work and Technology in a Post-Industrial Age 66-73, 132-34 (1984).

301. See supra text accompanying supra note 13 . 
at-work," and that we may thus respond to the discipline of a colleague the way we would if she were our parent, our child, or our spouse. ${ }^{302}$ (In many work settings, the disciplined worker may in fact be just that. ${ }^{303}$ ) Or perhaps what the employer has done strikes us as so unjust that we are moved to action out of a desire to vindicate some principle, quite apart from any feelings we may have for the directly affected employee. No one who has participated in a workplace protest, or defended one in court, or read widely in the field of labor history, can doubt that such motives are as frequently a cause of protest as naked self-interest. ${ }^{304}$

So, too, when the individual worker seeks the aid and support of others-or even takes a stand alone against the employer-in support of her own cause. Once again, self-interest may provide much of the basis for her action. Yet the same bonds that bring an employee to the aid of her colleague's claim may operate in this context as well: The lone protester may feel that the workplace family's interests, not just her own, are at stake in challenging the employer's conduct. Recall employee Brown in City Disposal, who-forced by his employer to choose between losing his job and driving an unsafe garbage truck-responded thus: " '[W] hat [are] you going to do, put the garbage ahead of the safety of the men?" "305 Lynd argues persuasively that Brown's invocation of the collective interest was neither artifice nor happenstance, that

302. In a family, when I as son, husband, or father, express love toward you, I do not do so in order to assure myself of love in return. I do not help my son in order to be able to claim assistance from him when I am old; I do it because he and $I$ are in the world together; we are one flesh. Similarly in a workplace, persons who work together form families-at-work. When you and I are working together, and the foreman suddenly discharges you, and I find myself putting down my tools or stopping my machine before I have had time to think-why do I do this? Is it not because, as I actually experience the event, your discharge does not happen only to you but also happens to us?

Lynd, supra note 295 , at 1427 (footnote omitted).

303. See, e.g., Morrison-Knudsen Co. v. NLRB, 358 F.2d 411, 412-13 (9th Cir. 1966) (father's protest on behalf of son); Washington Forge Inc., 188 N.L.R.B. 90,97 \& nn.28-30 (1971) (spouses' protest).

304. The mixture of self-interest, solidarity, and principle is perhaps nowhere better suggested than in the accounts of the recent union organizing campaign among the clericals at Harvard University. An official of the union representing the university's food service workers described the efforts of organizer Kris Rondeau thus:

[Rondeau] came in and reminded people what unions were all about. [President] Reagan said they were dinosaurs. Rondeau said, "let me redefine a union for you, show you what it's always been. It's not just for when wages are bad. You need it to question authority." The key is, Harvard has told people to be as selfish as possible, just like Reagan's been saying. That's really maybe what this referendum is about-whether this community is based on self-interest or on what Rondeau is talking about. Always bearing in mind, of course, that in the long run unions are in your self-interest too.

McKibben, Union Dues: Organizing Harvard, The Village Voice, June 28, 1988, at 18, 20.

305. NLRB v. City Disposal Sys., Inc., 465 U.S. 822, 827 (1984) (emphasis added). 
the employee cast his protest in the first-person plural "because this is how he experienced it." 306

As suggested earlier, the contemporaneous understanding of the expression "mutual aid or protection" was almost surely informed by such notions of solidarity and mutualism in the workplace. ${ }^{307}$ Why, then, do the Board and especially the courts reject the idea that employees who participate in workplace protests frequently act-and are entitled to act-for reasons apart from pure self-interest? One cannot help but wonder what is (or what else is) really going on when a rhetoric of justification is deployed that forces the decision makers to deny that they are doing just what they are, in fact, doing; after all, the results of the cases discussed frequently protect the protests at issue.

The persistence of the doctrine is perhaps all the more puzzling in view of the strenuous exercises the decision makers must undertake in order to make it work. For example, for cases in which employees offer their "aid and protection" to others, the decision makers must ignore record evidence and strain to establish that the protesters' self-interest, rather than simply their sense of loyalty to or solidarity with the protest beneficiaries, moved them to action. If the Board and the courts are going to extend legal protection to these activities in any event (and again, the cases suggest they often do), why go through all the work? To be sure, the Board and the courts are not, in the bulk of the cases, forced to undertake the sort of interpretive exercise to find self-interest that was necessary in, say, Hendricks or Eastex, since unmistakable evidence of protester selflessness seldom appears in as stark a fashion as it did in those cases. Yet this is surely due in no small part to the fact that labor litigators have learned that such facts do not get them very far. In any event, there are myriad other cases in which the circumstances strongly suggest that love or solidarity-and not merely self-interestprompted the protest in question, and rarely is there any evidence suggesting direct and bona fide protester self-interest. ${ }^{308}$

306. Lynd, supra note 295, at 1427 (emphasis added). City Disposal is not at all unusual in this respect. For another revealing example, see Bechtel Power Corp., 277 N.L.R.B. 882 (1985), where the discharged employee had repeatedly protested the presence of noxious fumes in the plant, only to be rebuffed by his employer's safety officer and told to "fix" his hard hat. Once again, the protester-though acting alone-spoke in terms suggesting that he experienced the confrontation as an integral part of his workplace family: "All you are worrying about [are] our hardhats, you are worried about our glasses, our eyes, but you are not too concerned about the air that we breathe." 'Id. at 883 (emphasis added). (Indeed, several other employees had previously become ill on account of the fumes. Id. at 882-83.) Recall as well employee Henley in Alleluia Cushion, many of whose safety complaints related primarily to the working conditions of his colleagues, rather than himself. See supra text accompanying note 166 .

307. See supra notes 264-77 and accompanying text.

308. Indeed, on at least one occasion, the Board could not make the self-interest argument with a straight face. See Supreme Optical Co., 235 N.L.R.B. 1432, 1433 (1978) (protecting employees testifying at unemployment compensation hearing of dis- 
The ubiquity of the "promise of reciprocal benefit" rhetoric in decisions construing the mutuality requirement seems to me to be attributable to a confluence of factors, some of which may contribute to its legitimating force as well. At the most banal level, of course, there are influences that arise from the institutional context. Except perhaps during periods of extraordinary retrenchment in employee rights, arguments that favor protection under section 7 will virtually always be made by the Labor Board's lawyers, ${ }^{309}$ and the presence of a repeat player with a powerful institutional memory can have a dramatic-and quite conservative-impact on the way cases are pitched to the judiciary. (I can almost hear one of the deputy assistant general counsels I worked with now: "Defending a sympathy striker? No problem. Look up that Hand opinion in Peter Cailler; and you might want to take a peek at our brief in Eastex.") There is also the compelling attraction of the counterintuitive and the clever in legal reasoning. The lawyer's intrigue with a doctrinal device like the Peter Cailler principle may be attributable precisely to its capacity to "turn the facts on their head"; it is thus, in Karl Llewellyn's magnificent phrase, much like "the RabbitHole down which we fell into the Law, and to him who has gone down it, no queer phenomenon is strange." 310 But the presence of the

charged fellow employee but observing that a reciprocal benefit to the witnesses was "not likely ... inasmuch as the one being helped was no longer an employee and hence could not be in a position to reciprocate to the [employees] attending the hearing on his behalf"), enforced, 628 F.2d 1262 (6th Cir. 1980) (enforcing order on the facts but rejecting Board's apparent per se rule that "attendance at an unemployment compensation hearing is always protected activity"), cert. denied, 451 U.S. 937 (1981).

I am not suggesting that workers always (or even as often as not) act for other than selfish reasons; there is no reason to suspect that they differ significantly in this respect from anyone else. As Professor Atleson has wryly observed, labor's "voraciousness, of course, is generally, and unfavorably, contrasted to the motivation of all other Americans[,] who are perfectly happy to strive for less and less." J. Atleson, supra note 4 , at $206 \mathrm{n} .13$. I mean only to describe the strange reaction of the Board and the courts in the many cases in which it appears that employees are in fact moved by selflessness.

309. Because there is no private right of action under the Act, argnments by private parties for broader readings of the provision will occur in the relatively rare-and seldom successful-context of a petition for review of a Board order by a losing charging party. Charging parties who prevail before the Board may, of course, intervene in the subsequent enforcement proceedings as a matter of right; but the litigious prerogative of the Board's general counsel will usually preclude them from asserting theories of the case that differ substantially from her official line.

3I0. Llewellyn, On Our Case-Law of Contract: Offer and Acceptance, 48 Yale L.J. 1, 32 (I938). Llewellyn's account of the remarkable persistence of contract law doctrines that misunderstood commercial life is apt here:

The rules of Offer and Acceptance . . . have a grip on the vision and indeed on the affections held by no other rules "of law," real or pseudo. For it was Offer and Acceptance which first led each of us out of laydom into The Law. Puzzled, befogged, adrift in the strange words and technique of cases, with only our sane feeling of what was decent for a compass, we felt the warm sun suddenly, we knew that we were arriving, we knew we too could "think like a lawyer": That was when we learned to down seasickness as A revoked when $B$ was al- 
search for self-interest elsewhere in-and even outside of-section 7 doctrine suggests that it resonates with something deeper and more pervasive in American labor law. 311

Upon reading an earlier draft of this article, a colleague of mine exclaimed, "Women sure are troublemakers!" At first 1 thought he was teasing me for my decision to use feminine pronouns to refer to the generic employee, but instead he had noted the striking number of cases (including, most notably, Hendricks and Wheeling Electric) in which the protesting employee was indeed a woman. Perhaps this is no coincidence. The notion that women may experience the connection between self and others as "relational"-rather than in male-grounded "oppositional" terms-has been eloquently explored in feminist literature and jurisprudence. ${ }^{312}$ That Mary Weatherman would risk her job to sigu a petition calling for the reinstatement of her disabled colleague-that lmogene McConnell would do the same in order to honor a picket line established by coworkers in a union to which she could not belong-may well be manifestations not only of a spirit of mutualism born of the experience of worklife and oppression, but also of "a gender difference in the value that people place on relationships." 313 More importantly, however, the decisions that would deny these courageous women their section 7 claims-or insist that they disguise the true nature of their actions in order to gain the provision's protectionseem to reveal the assumptions about the oppositional forms of human association that the feminists have so astutely unearthed and rightly criticized.

A further explanation for the power of these assumptions-one that is closely related to the feminist critique-suggests itself when we

most up the flag-pole. Within the first October, we had achieved a technical glee in justifying judgment then for A; and succulent memory lingers, of the way our dumher brethren were pilloried as Laymen still. This is therefore no area of "rules" to be disturhed. It is an area where we want no disturhance, and will brook none. It is the Rabbit-Hole down which we fell into the Law, and to him who has gone down it, no queer phenomenon is strange; he has been magicked; the logic of Wonderland we then entered makes mere discrepant decision negligible. And it is not only hard, it is obnoxious, for any of us who have gone through that experience to even conceive of Offer and Acceptance as Id. perhaps in need of re-examination.

311. Or for that matter, American law generally. Indeed, my colleague Steve Winter has uncovered a similar search for self-interest-with similarly distorting effects upon efforts to translate the experience of community into law-in the jurisprudence of article III "standing." See Winter, The Metaphor of Standing and the Problem of SelfGovernance, 40 Stan. L. Rev. 1371 (1988).

312. See, e.g., Whitbeck, A Different Reality: Feminist Ontology, in Beyond Domination: New Perspectives on Women and Philosophy 64 (C. Gould ed. 1984); Scales, The Emergence of Feminist Jurisprudence: An Essay, 95 Yale L.J. 1373, 1380-84 (1986); Coombs, Shared Privacy and the Fourth Amendment, or the Rights of Relationships, 75 Calif. L. Rev. 1593, 1598-99 (1988).

313. Coombs, supra note 312 , at 1598 . 
shift our focus from the images of the relationship between self and others among employees articulated in the opinions, and look instead to the unarticulated image of the relationship between employees and the other "other" in the workplace: the employer. My sense is that the ritual incantation of the "promise of reciprocal benefit" rhetoric results in no small part from our tendency to imagine the employment relationship as an abstract contractual exchange, rather than as an experientially grounded network of human relationships. ${ }^{314}$ This contractual imagery-which posits a world made up of separate, self-interested individuals dealing with each other at arm's length-has a surprisingly durable hold on modern liberal thought, ${ }^{315}$ and it may well play a significant role in concealing the possibility of a richer worklife from the minds of legal decision makers. ${ }^{316}$

It is surely the case that the commitment to a regime of self-interest has an instrumental component as well. Resistance to legal protection for worker solidarity qua solidarity is of a piece with a host of other labor doctrines-among them the rules proscribing secondary boycotts, ${ }^{317}$ the prohibition against union expenditure of agency fees for "political" and organizing activities, ${ }^{318}$ and the narrow "community-ofinterest" standard in bargaining unit determinations ${ }^{319}$ - that operate to discourage and undermine working class alliances. Together, these rules do indeed suggest a strategy developed to "divide and conquer"

314. See generally the discussion of commodity fetishism in G. Lukacs, History and Class Consciousness: Studies in Marxist Dialectics 83 (1971) (Livingstone, R., trans.):

The essence of commodity-structure has often been pointed out. Its basis is that a relation between people takes on the character of a thing and thus acquires a "phantom objectivity," an autonomy that seems so strictly rational and all-embracing as to conceal every trace of its fundamental nature: the relation Id. between people.

315. For a classic example, see C. Fried, Contract as Promise: A Theory of Contractual Obligation 7-8 (1981).

316. In a wonderful recent piece on the constitutional doctrines governing labor's right to strike and picket, James Gray Pope has noted the staying power of this "commodity theory of labor," first developed in late nineteenth century jurisprudence. See Pope, Labor and the Constitution: From Abolition to Deindustrialization, 65 Tex. L. Rev. 1071 (1987); see also Casebeer, supra note 2, at 783-93 (describing continuing effect of late nineteenth and early twentieth century contract imagery in American employment law).

317. See N.L.R.A. § 8(b)(4), (e), 29 U.S.C. § 158(b)(4), (e) (1982).

318. See Communication Workers of Am. v. Beck, 108 S. Ct. 2641, 2645, 2657 (1988) (Labor Act "authorizes the exaction of only those fees and dues necessary to performing the duties of an exclusive representative of the employees in dealing with the employer on labor-management issues" " (citation omitted)); see also supra note 19 (discussing limits on $\$ 7$ protection for "political" protests).

319. See J. Rogers, Divide and Conquer: The Legal Foundations of Postwar U.S. Labor Policy (forthcoming 1989 Wis. L. Rev.) (arguing that Board determinations under this standard are "largely determined by prior management choices concerning operations, integration, employee grouping and manner of supervision, and differentiated patterns of wages and benefits already conferred"). 
working people and thus diminish the likelihood of effective economic and political action on their part against those who employ them. ${ }^{320}$

There is one last phenomenon that may account for the resilience of the Peter Cailler principle. Liberal lawyers, judges, Board members, and even law professors may routinely make the quite conscious choice to fashion legal arguments that accept the premises of the regime of self-interest in order to persuade what they correctly see as a far more conservative legal order to provide legal protection against employer retaliation for a particular protest or form of protest activity. To be sure, one is not likely to win individual labor cases (or anything else, for that matter) by urging the courts to undertake a wholesale restructuring of the conceptual foundations of American labor law. But the point of this Article is that ideas matter and that legal arguments eventually come home to haunt. Thus, we must struggle to expand labor law discourse to give voice to the experience of solidarity and mutualism among working people-a voice that does not force them to cast their conduct in the distorting and alienating rhetoric of self-interest.

\section{ConcLusion}

The current interpretation of section 7's mutuality requirement justifies protection for employee protests in the narrow self-interest of those who come or are called to the aid of their working colleagues. A more capacious reading-one that would forthrightly protect solidarity as well as self-interest-would be consistent with congressional efforts through the Norris-LaGuardia and Wagner Acts to limit the prerogatives of the judiciary in policing the protest activities of labor. It would, moreover, vindicate the contemporaneous understanding of the expression "mutual aid or protection," an understanding that is, ironically, evident in and embraced by Peter Cailler itself. Such a reading might also bring a salutary challenge to our impoverished images of the employment relationship and to labor law's current resistance to working class cohesion.

320. See generally id. (describing and criticizing divisive effects of various labor doctrines). 